2. Io: (Receiving organization)

Distribution

5. Proj./Prog./Dept./Div.:

Spent Nuclear Fuel Project

8. Originator Remarks:

Drying studies, performed in France, for uranium hydrate.

3. From: (Originating Organization) SNF Characterization Project

6. Design Authority/ Design Agent/Cog. Engr.:

Nite T. A. FTament

7. Purchase Order No.:

$N / A$

9. Equip./Component No.:

$N / A$

10. System/Bldg./Facility:

N/A

11. Receiver Remarks: 11A. Design Baseline Document? [] Yes $[X]$ No

12. Major Assm. Dwg. No.:

$N / A$

13. Permit/Permit Application No.: $N / A$

14... Required Response Date: $\mathrm{N} / \mathrm{A}$

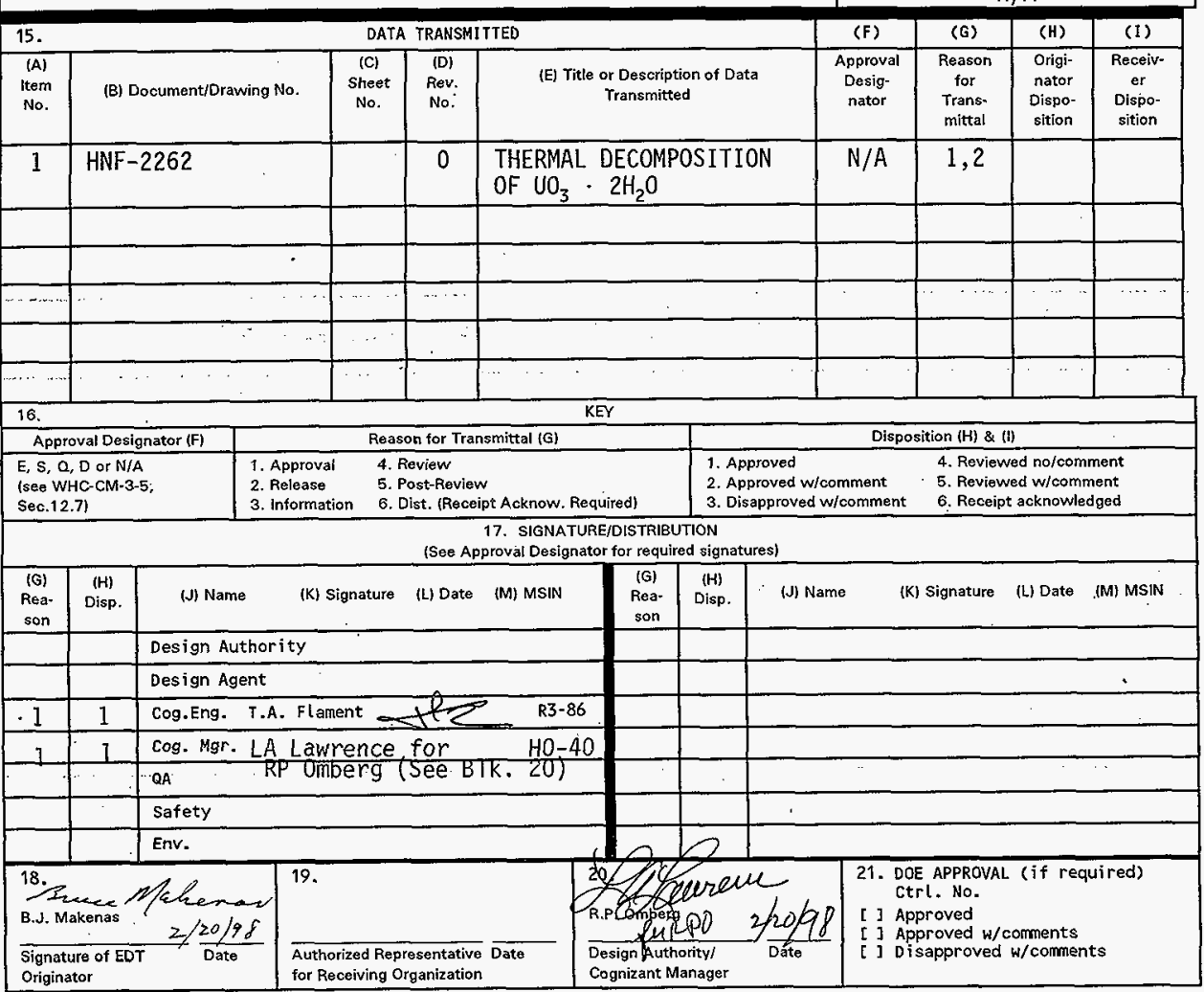


HNF-2262, Rev. 0

\title{
THERMAL DECOMPOSITION OF $\mathrm{UO}_{3} \cdot 2 \mathrm{H}_{2} \mathrm{O}$
}

\author{
T. A. Flament
}

Numatec Hanford, Richland, WA 99352

U.S. Department of Energy Contract DE-AC06-96RL13200

EDT/ECN: 620800

Org Code: 2 T720

UC: 2070

B\&R Code: EW7040000

Charge Code: LB074

Total Pages: $-74_{\text {pa }} 75$

Key Words: K Basin, Uranium Hydrate, Thermo-Gravimetric Analysis

Abstract: The first part of the report summarizes the literature data regarding the uranium trioxide water system. In the second part, the experimental aspects are presented. An experimental program has been set up to determine the steps and species involved in decomposition of uranium oxide di-hydrate. Particular attention has been paid to determine both loss of free water (moisture in the fuel) and loss of chemicaliy bound water (decomposition of hydrates). The influence of water pressure on decomposition has been taken into account.

TRADEMARK DISCLAIMER. Reference herein to any specific comercial product, process, or service by trade name, trademark, manufacturer, or otherwise, does not necessarily constitute or imply its endorsement, recommendation, or favoring by the United States Government or any agency thereof or its contractors or subcontractors.

Printed in the United States of America. To obtain copies of this document, contact: Document Control Services, P.0. Box 950, Mailstop H6-08, Richland WA 99352, Phone (509) 372-2420; Fax (509) 376-4989.
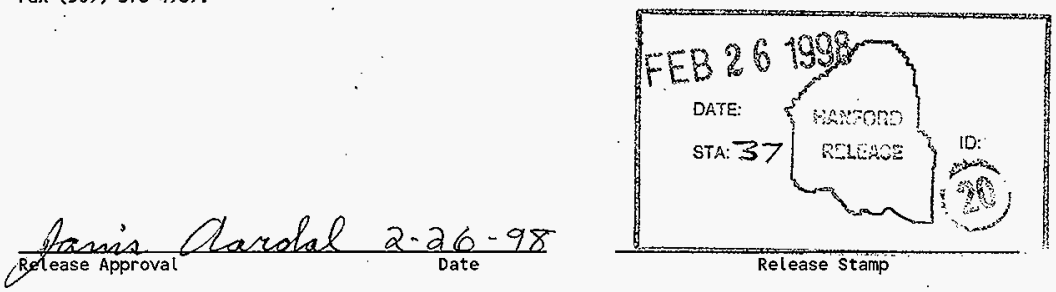
HNF-2262 Rev.0

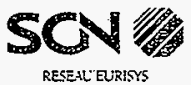

78182 ST QUENTIN YVELINES CEDEX FRANCE

Tél. $\div 33139485000-$ Télex 698316F

Fax: $+33 \ 39486061$

\begin{tabular}{|c|c|c|c|c|}
\hline $\begin{array}{l}\text { Type Dos. } \\
\mathrm{NT}\end{array}$ & $\begin{array}{r}\text { Aetivite } \\
10510\end{array}$ & $\begin{array}{l}\text { Cotint } \\
00\end{array}$ & $\begin{array}{l}\text { No sorde } \\
0004\end{array}$ & $\begin{array}{l}\text { Révision } \\
\text { Rév. A }\end{array}$ \\
\hline Unite & Emc & & $\mathrm{CMT}$ & Situzstion \\
\hline $000^{\circ}$ & $\mathrm{P} 2$ & & 00 & 0.000 \\
\hline
\end{tabular}

TECHNICAL NOTE

THERMAL DECOMPOSITION OF $\mathrm{UO}_{3}, 2 \mathrm{H}_{2} \mathrm{O}$.

\begin{tabular}{|l|l|l|l|}
\hline Rev. & \multicolumn{1}{|c|}{ Written } & \multicolumn{1}{|c|}{ Checked } & \multicolumn{1}{c|}{ Approved } \\
\hline A & $\begin{array}{l}\text { P.BILARDELLO } \\
\text { The } 01-22-98\end{array}$ & $\begin{array}{l}\text { F.DRAN } \\
\text { The } 01.22-98\end{array}$ & $\begin{array}{l}\text { F. DRAIN } \\
\text { The } 01-2298\end{array}$ \\
\hline
\end{tabular}


HNF-2262 Rev. 0

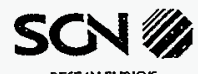

\section{CHRONOLOGY OF REVISIONS}

Rev.

Date, Review number, Signatories and identification of modified paragraphs

A Approved on: 01.22 .93

Control number : 97352000664

Written by :P. BILARDELLO

Checked by : F. DRAIN

Approved by : F. DRAIN 
HNF-2262 Rev. 0

\section{SUMMARY}

1. . BACKGROUND AND PURPOSE: 4

2. URANIUM TRIOXIDE - WATER SYSTEM …….........................................5

2-1 URANIUM TRIOXIDE HYDRATES ......................................................... 5

2-2 THERMAL DECOMPOSITION OF DI-HYDRATE UO3, 2H2O ................ 5

3. EXPERIMENTAL_................................................................................... 8

3.1. SCOPE AND PROGRAM ………………………........................................ 8

3.2. FIRST PHASE - SYNTHESIS OF MATERIALS ......................................... 10

3.3. SECOND PHASE : REACTION PATH ...................................................... 11

3-4 THIRD PHASE : KINETICS DATA .......................................................... 14

3.4 INTERPRETATION .......................................................................... 16

$4 \quad$ KINETIC MODEL

4-1 . MODEL DESCRIPTION ......................................................................... 18

4-2 DENTIFICATION METHOD ……....................................................... 19

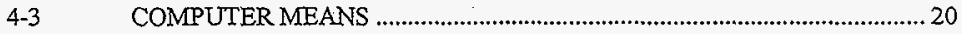

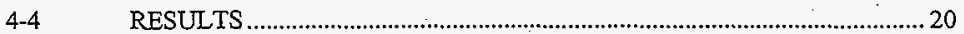

5 CONCLUSION 
HNF-2262 Rev. 0

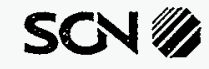

RESEAU EURISTS

\begin{tabular}{|lrlll|}
\hline Type Doc. & Acrivite & Cas NT & No dordte & Résision \\
NT & 10510 & 00 & 0004 & Rév, A \\
\hline
\end{tabular}

Page : $4 / 74$

BIBLIOGRAPHY. 22

APPENDIX 1 EXPERIMENTAL DEVICE 24

APPENDIX 2 SECOND PHASE : DTG/ATD CURVES 27

APPENDIX 3 THIRD PHASE : TGD/TDA CURVES 35

APPENDIX 4 WATER PRESSURE 42

APPENDIX 5 WATER FREE .44

APPENDIX 6 KINETIC MODEL 48

APPENDIX 7 COMPARISON , CURVES : RUNS USED IN IDENTIFICATION 51

APPENDIX 8 COMPARISON CURVES : RUNS CARRIED OUT WITH MOISTURE ATMOSPHERE. 56

APPENDIX 9 WEIGHT SPECIES VARUATION 60

APPENDIX 10 X-RAY DIFFRACTION PATTERN RUN ES08 AND ES12 (AFTER 1H3OMN OF HEATING TIME). 64

APPENDIX 11 PREDICTED MAAS LOSS IN HEATING CONDITIONS OF KE CANISTER SLUDGE 96-08 (RUN 46 OF [10]). 67

APPENDIX 12 PARTICULE-SIZE DISTRIBUTIONOF THE TWO SAMPLES 


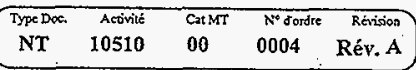

\section{BACKGROUND AND PURPOSE}

This study is performed in the frame of the Spent Nuclear Fuel (S.N.F) project. The scope of the project is to remove fuel and sludge from basins and to pack it to ensure a storage complying with environmental constraints. The residence time in basins have induced some evolution of spent nuclear fuel. The uranium transformation into $\mathrm{UO}_{3}$ hydrates and the fuel moisture require a drying process of spent nuclear fuels.

The literature provides very little information on decomposition rates of uranium oxides hydrates. These information are necessary to support the modelling of the drying process. The scope of this study is to determine $\mathrm{UO}_{3}, 2 \mathrm{H}_{2} \mathrm{O}$ decomposition rates as a function of temperature up to $400^{\circ} \mathrm{C}$ and water pressure in the range from 0 to $40 \mathrm{kPa}$.

The first part of the report summarises the literature data regarding the uranium trioxide water system

In the second part experimental aspect is presented. An experimental program has been set up to determine the steps and species involved in decomposition of uranium oxide di-hydrate. A particular attention has been paid to determine both loss of free water (moisture of the fuel) and loss of chemical bound water (decomposition of hydrates). The influence of water pressure on decomposition has been taken into account.

The experimental means are thermogravimetric analyses (T.G.A) coupled with differential thermal analysis (D.T.A.), X-ray diffraction, granulometric, and chemical analysis.

The third part of this report deals with the model to predict thermal decomposition of uranium oxide hydrate. The method used to built in the kinetic model, with an appropriate exploitation of experimental data, is explained.

Arguments about validity and limit of this model are developed in conclusion of this report. 


\section{URANIUM TRIOXIDE - WATER SYSTEM}

\section{2-1 URANIUM TRIOXIDE HYORATES}

Different crystalline phases and chemical compositions of uranium trioxide hydrates are listed in table 1.

All the authors agree on the presence of hydrates $\mathrm{UO}_{3}, 2 \mathrm{H}_{2} \mathrm{O} ; \mathrm{UO}_{3}, \mathrm{H}_{2} \mathrm{O} ; \mathrm{UO}_{3}, 0.5 \mathrm{H}_{2} \mathrm{O}$. Discussion remains about the existence of hydrates $\mathrm{UO}_{3}, \mathrm{xH}_{2} \mathrm{O}$ with $0.7<\mathrm{x}<0,9$. These hydrates are usually named dehydrated schoepite (DS).

The effect of heat treatment on a pure monohydrate involves an inreversible distortion of $\mathrm{UO}_{3}, \mathrm{H}_{2} \mathrm{O}$ crystalline lattice. [4] which induces a modification of the hydration degree. This distortion is identified with thermal gravimetric analysis coupling with $X$-ray diffraction. The $\mathrm{X}$-ray patterns of the different dehydrated schoepite $\mathrm{UO}_{3}, \mathrm{xH}_{2} \mathrm{O}$ are very similar. The peaks position are almost the same but the relative intensities are different (table 2).

\section{2-2 THERMAL DECOMPOSITION OF DI-HYDRATE $\mathrm{UO}_{3}, 2 \mathrm{H}_{2} \mathrm{O}$}

Dawson [5] and Danroc [3] have proposed the same thermal decomposition path although the experimental conditions were different :

$$
\mathrm{UO}_{3}, 2 \mathrm{H}_{2} \mathrm{O} \rightarrow \mathrm{UO}_{3}, \mathrm{H}_{2} \mathrm{O} \rightarrow \mathrm{UO}_{3} 0,8 \mathrm{H}_{2} \mathrm{O} \rightarrow \mathrm{UO}_{3}
$$

The Danroc [3] conditions are ambient temperature during five hours followed by a temperature increase rate of $5^{\circ} \mathrm{C} / \mathrm{mn}$. The pressure is 10 torr. The Dawson [5] conditions is a temperature increase rate of $2^{\circ} \mathrm{C} / \mathrm{mn}$, and atmospheric pressure.

The purpose of Danroc works is to study $\mathrm{UO}_{2}$ ageing in moisture atmosphere. The samples composition are mixtures of $\mathrm{UO}_{2}$ and $\mathrm{UO}_{3}, 2 \mathrm{H}_{2} \mathrm{O}$.

In the case of Dawson [5], identification of uranium trioxide hydrates have been studied. The samples are constituted by pure $\mathrm{UO}_{2}, 2 \mathrm{H}_{2} \mathrm{O}$.

The $\mathrm{UO}_{3}, \mathrm{H}_{2} \mathrm{O}$ are clearly identified by X-ray diffraction. The X-ray analysis don't permit the conclude between $\mathrm{UO}_{3}, 0,8 \mathrm{H}_{2} \mathrm{O}$ and $\beta$ crystalline form of $\mathrm{UO}_{3}, \mathrm{H}_{2} \mathrm{O}$. In the two works $\mathrm{UO}_{3}, 0,8 \mathrm{H}_{2} \mathrm{O}$ has been deduced from mass loss analysis in thermal decomposition process. 
HNF-2262 Rev, 0

\begin{tabular}{|c|c|c|c|c|c|c|}
\hline \multirow[t]{2}{*}{ FORMULA } & \multirow{2}{*}{$\begin{array}{l}\text { Molat } \\
\text { weight } \\
\mathrm{g} / \mathrm{mol}\end{array}$} & \multicolumn{3}{|c|}{ Weight percent } & \multirow[b]{2}{*}{$\mathrm{H} 2 \mathrm{O}$} & \multirow{2}{*}{$\begin{array}{l}\text { Loss mass } \\
\text { percent - Base } \\
\mathrm{UO} 3,2(\mathrm{H} 2 \mathrm{O})\end{array}$} \\
\hline & & $\dot{U}$ & 0 & $\mathrm{H}$ & & \\
\hline UO2 & 270 & 88.15 & 11.85 & - & - & 16.15 \\
\hline UO3 & 286 & 83.22 & 16.78 & - & - & 11.18 \\
\hline U308 & 842 & 84.80 & 15.20 & - & - & 12.84 \\
\hline $\mathrm{UO} 3,2(\mathrm{H} 2 \mathrm{O})$ & 322 & 73.91 & 24.84 & 1.24 & 11.18 & - \\
\hline $\mathrm{UO} 3,(\mathrm{H} 2 \mathrm{O})$ & 304 & 78.29 & 21.05 & 0.66 & 5.92 & 5.59 \\
\hline$(\mathrm{UO} 3,0.8(\mathrm{H} 2 \mathrm{O})$ & 300.4 & 79.23 & 20.24 & 0.53 & 4.79 & 6.71 \\
\hline$(\mathrm{UO} 3,0.5(\mathrm{H} 2 \mathrm{O})$ & 295 & 80.68 & 18.98 & 0.34 & 3.05 & 8.39 \\
\hline
\end{tabular}

\begin{tabular}{|c|c|c|}
\hline Crystallography & Colour & Crystalline type \\
\hline$\overline{\mathrm{UO3}}$ & $\begin{array}{l}\text { dark orange } \\
\text { clear yellow }\end{array}$ & $\begin{array}{c}\text { amorphous } \\
\alpha\end{array}$ \\
\hline $\mathrm{UO} 3,2(\mathrm{H} 2 \mathrm{O})$ & $\begin{array}{c}\text { yellow } \\
\text { green-yellow }\end{array}$ & $\begin{array}{l}\alpha \\
\beta\end{array}$ \\
\hline $\mathrm{UO} 3,(\mathrm{H} 2 \mathrm{O})$ & orange-yellow & $\begin{array}{l}\alpha \\
\beta \\
\gamma \\
\delta\end{array}$ \\
\hline
\end{tabular}

\begin{tabular}{|c|c|c|c|c|c|}
\hline $\begin{array}{l}\text { Decomposition enthalpies } \\
\text { and pressure equilibrium }\end{array}$ & $\begin{array}{c}\Delta \mathrm{H} \\
\mathrm{kJ} / \mathrm{mol}\end{array}$ & $\begin{array}{l}\mathrm{HH} \\
\mathrm{J} / \mathrm{g}\end{array}$ & $\begin{array}{c}\mathrm{P}\left(25^{\circ} \mathrm{C}\right) \\
\mathrm{kPa}\end{array}$ & $\begin{array}{c}\mathrm{P}\left(100^{\circ} \mathrm{C}\right) \\
\mathrm{kPa}\end{array}$ & $\overline{\mathrm{REF}}$ \\
\hline $\mathrm{UO} 3,2 \mathrm{H} 2 \mathrm{O} \ldots \mathrm{UO} 3, \mathrm{H} 2 \mathrm{O}+\mathrm{H} 2 \mathrm{O}$ & 51.4 & 159.6 & 1.4 & 92.20575 & Tा \\
\hline $\mathrm{UO} 3, \mathrm{H} 2 \mathrm{O} \ldots \mathrm{UO} 3,0.8 \mathrm{H} 2 \mathrm{O} \div 0.2 \mathrm{H} 2 \mathrm{O}$ & 5.5 & 18.1 & & & [3] \\
\hline $\mathrm{UO} 3,0.8 \mathrm{H} 2 \mathrm{O}-\mathrm{-.}>\mathrm{UO} 3(\mathrm{~mm}) \div 0,8 \mathrm{H} 2$ & 77.6 & 258.3 & & & [1] \\
\hline $\mathrm{UO} 3,2 \mathrm{H} 2 \mathrm{O} \ldots . . \mathrm{UO} 3+2 \mathrm{H} 2 \mathrm{O}$ & 120.1 & 373.0 & & & [3] \\
\hline $\mathrm{UO} 3,2 \mathrm{H} 2 \mathrm{O} \ldots \mathrm{UO} 3(\mathrm{am})+2 \mathrm{H} 2 \mathrm{O}$ & 134.5 & 417.7 & & & [1] \\
\hline $\mathrm{UO} 3, \mathrm{H} 2 \mathrm{O} \ldots \mathrm{UO} 3+\mathrm{H} 2 \mathrm{O}$ & 69.0 & 227.0 & & & [3] \\
\hline $\mathrm{UO} 3, \mathrm{H} 2 \mathrm{O} \ldots \mathrm{UO} 3(\mathrm{am})+\mathrm{H} 2 \mathrm{O}$ & 83.1 & 273.4 & & & [1] \\
\hline
\end{tabular}


HNF-2262 Rev. 0

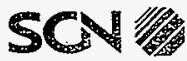

\begin{tabular}{|lrlll|}
\hline Type Doc. & Activite & C2!MT & No dotde & Révition \\
NT & 10510 & 00 & 0004 & Rév. A \\
\hline
\end{tabular}

Page $: 8 / 74$

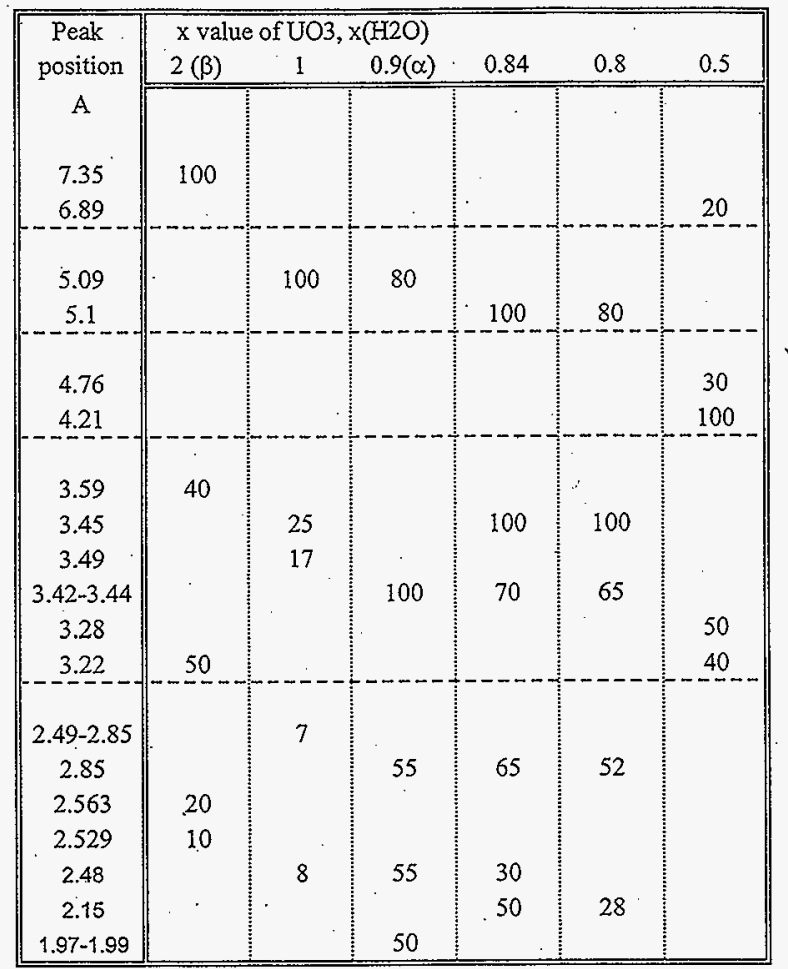

Table.2 - X-ray diffraction pattern of $\mathrm{UO}_{3}, \mathrm{xH}_{2} \mathrm{O}$ - relative intensities 


\section{EXPERIMENTAL}

\subsection{SCOPE AND PROGRAM}

The experimental program has been divided into three phases.

The scope of the first phase is to synthesise the hydrate $\mathrm{UO}_{3}, 2 \mathrm{H}_{2} \mathrm{O}$.

This material has been synthesised in two ways from anhydrous $\mathrm{UO}_{3}$,by immersion into water and by sweeping wet air. In the first case, a mixture of $\mathrm{UO}_{3}, 2 \mathrm{H}_{2} \mathrm{O}$ and $\mathrm{H}_{2} \mathrm{O}$ has been obtained in the second case pure $\mathrm{UO}_{3}, 2 \mathrm{H}_{2} \mathrm{O}$ has been obtained. These two ways of synthesis will allow during the second phase to determine during deconiposition both loss of free water and loss of chemical bound water.

The final products are analysed using $X$-ray diffraction. The uranium composition of initial and final products are verified by chemical analysis. Granulometric analysis have been made on the two final products.

The second and third phase consists to study the thermal decomposition of these two. products. A. D.T.G./D.T.A. diagram is obtained for each run of the second and third phase. The diagram includes three curves for each run .

- The T.G. curve gives the mass loss percent, $100 \%$ corresponding to the initial mass sample.

- The D.T.G. curve gives the mass loss time derived.

- The D.T.A. curve gives the heat flow between sample and the heat spring.

A blank test is made for each experimental runs. It consists to apply the programmed temperature profile to a standard product $\left(\mathrm{Al}_{2} \mathrm{O}_{3}\right)$ which is chemically stable in the used range of temperature. The initial mass is same as mass of sample and the recording of mass evolution allows to correct the base line of mass loss curve with respect of temperature evolution. All the curves submitted in this report take a specific blank test into account.

The accuracy of mass measurement is higher than $0.1 \mathrm{mg}$ for a initial sample mass of 50 $\mathrm{mg}$. This accuracy has been estimated for with a product (sodium oxalate) for which theoretical thermal decomposition is compared with measured mass loss.

The heat flow allows to evaluate the enthalpies of the different phenomena. Sensibility coefficient have been determinated in the temperature range of this study with known fusion enthalpies of standard metals. The accuracy is good for high temperature ( $10 \%$ of the absolute value). For temperature less than $150^{\circ} \mathrm{C}$, sensibility coefficients are not known accurately. The enthalpies accuracy for temperature less than $150^{\circ} \mathrm{C}$ is unknown, the enthalpies values is to take like an indication and not in absolute. 
The main objective of the second phase is to obtain information on the various species involved during thermal decomposition and the influence of the water pressure .

The test have been performed using argon atmosphere with vapour pressure in the range of 0 to $40 \mathrm{kPa}$. The two different samples of $\mathrm{UO}_{3}, 2 \mathrm{H}_{2} \mathrm{O}$ have been used (with and without free water). The temperature range is from $20^{\circ} \mathrm{C}$ to $500^{\circ} \mathrm{C}$. Two heating rate have been used $\left(5^{\circ} \mathrm{C} / \mathrm{mn}\right.$ and $\left.0,5^{\circ} \mathrm{C} / \mathrm{mn}\right)$.

The scope of the third experimental phase is to obtain enough experimental data to perform a suitable kinetic models. The experimental data have been obtained by heating samples at a constant temperature. The condition of temperature and water pressure, are adjusted according to the results of the precedent phase. 


\begin{tabular}{|rrlrr|}
\hline Type Doc: & Activite & Cat $M T$ & $N^{\circ}$ Gotdrs & Révision \\
NT & 10510 & 00 & 0004 & Rév, A \\
\hline
\end{tabular}

Page : $11 / 74$

\subsection{FIRST PHASE - SYNTHESIS OF MATERIAIS}

The $\mathrm{UO}_{3}$ powder are synthesised in two steps :

- oxidation of dioxide uranium $\left(\mathrm{UO}_{2}\right)$ by hydrogen peroxide $\left(\mathrm{H}_{2} \mathrm{O}_{2}\right)$ to yield uranium peroxide $\left(\mathrm{UO}_{4}\right)$

- drying and calcination of $\mathrm{UO}_{4}$.

The $\mathrm{UO}_{3}$ powder is grinned and characterised by $\mathrm{x}$-ray diffraction. The amount of uranium is determined by chemical analysis.

The di-hydrate $\mathrm{UO}_{3}, 2 \mathrm{H}_{2} \mathrm{O}$ is then prepared either by sweeping wet air or by immersion in water. In the two cases, the preparation time is 148 hours. In the first case after $24 \mathrm{~h}$, the $\mathrm{X}$-ray diffraction indicates that the sample is pure di-hydrate. The two samples of dihydrates $\mathrm{UO}_{3}, 2 \mathrm{H}_{2} \mathrm{O}$ synthesised have the same X-ray diffraction and the same yellow colour at the end of preparation.

The table 3 summarises the reagents characteristics. The difference between measured and theoretical uranium percentage may result of the synthesis process of $\mathrm{UO}_{3}$. $\mathrm{The}^{\mathrm{UO}}$ synthesised could not be completely anhydrous, a part could be already converted in hydrate. This hypothesis is confirmed by the negligible difference between theoretical and measured uranium percent in pure $\mathrm{UO}_{3}, 2 \mathrm{H}_{2} \mathrm{O}$.

The difference between theoretical and measured weight of $U$ has been assimilated at free water. The calculated free water percent has been reported in table 3 .

Appendix 12 presents the particle-size distribution of the two samples. The particle size distribution of the sample synthesised by immersion into water shows that $50 \%$ of the population have a size less than $1 \mu \mathrm{m}$, and two size-distribution maximum have been identified, one at $1 \mu \mathrm{m}$ and the other at $50 \mu \mathrm{m}$. The synthesis method could be induce the partial destruction of rubbles.

The particle-size distribution of di-hydrate synthesised by sweeping wet air shows that $50 \%$ of the population have a size less than $193,5 \mu \mathrm{m}$, the size-distribution is centered around $300 \mu \mathrm{m}$

\begin{tabular}{|c|c|c|c|c|c|}
\hline & $\begin{array}{r}\mathrm{W} \\
\text { Perc } \\
\text { measure }\end{array}$ & fu & $\begin{array}{c}\text { Particule } \\
\text { size } \\
10 \mathrm{e}-6 \mathrm{~m}\end{array}$ & $\begin{array}{c}\text { X-ray } \\
\text { diffraction } \\
\text { identification }\end{array}$ & $\begin{array}{l}\text { Calculed } \\
\text { water } \\
\text { percent }\end{array}$ \\
\hline UO3 anbydrous & 79.7 & 83.2 & - & - & 4.21 \\
\hline $\mathrm{UO} 3,2 \mathrm{H} 2 \mathrm{O}$ synthesised by sweping wet air & 73.6 & 73.9 & 193.5 & $\mathrm{UO} 3,2 \mathrm{H} 2 \mathrm{O}$ & 0.41 \\
\hline $\mathrm{UO} 3,2 \mathrm{H} 2 \mathrm{O}$ synthesised by immersion into water & 49.9 & 73.9 & 1 & $\mathrm{UO} 3,2 \mathrm{H} 2 \mathrm{O}$ & 32.48 \\
\hline
\end{tabular}


HNF-2262 Rev. 0

\subsection{SECOND PHASE : REACTION PATH}

Appendix 1 presents the experimental device, a slight modification have been made after the run ESO3 to improve temperature control of inlet and outlet gases. This modification does not affect the results.

Table 4 indicates the experimental conditions of the seven experiments.

Table 5 summarises the resuits of mass loss and endothermic peaks.

Appendix 2 gathers the D.T.G./D T.A. curves of the first phase.

For all runs, the mass loss curve presents two plateau: the first between $150^{\circ} \mathrm{C}$ and $350^{\circ} \mathrm{C}$, the second after $400^{\circ} \mathrm{C}$. Two endothermic peaks (D.T.A. curves) can be associated with the two plateau : the furst between 138 and $159^{\circ} \mathrm{C}$ and the second between $345^{\circ} \mathrm{C}$ and $364^{\circ} \mathrm{C}$.

The curves of runs ES02 to ES06 presents a slight mass loss and an endothermic peak for temperature lower than $90^{\circ} \mathrm{C}$. This phenomena is linked to the experimental operating procedure used to fix a water pressure in wet atmosphere without condensation risk. The runs are started with dry gas; when saturation temperature is reached for a fixed water pressure the wet gas are send and the dry gas stopped.

The mass loss curve of nun ESO6 presents a third plateau after $475^{\circ} \mathrm{C}$.

The run ES07 hàs been made with the sample $n^{\circ} 1$ which contains $32 \%$ of free water. The mass loss curve presents also two plateau, positions of which are the same but the mass loss is more important for the first plateau. Two supplementary endothermic peaks can be identified for temperature, lower than $160^{\circ} \mathrm{C}$.

The X-ray diffraction patterns of the final products of all runs can be clearly identified $\mathrm{UO}_{3}$. For all runs except the run ES06, an amorphous phase can exist, the base line is not a continuous straight line. For the run ES06, the amorphous phase in not identified and the peak intensity of $\alpha U O 3$ increase with regard to the other runs.

Three peaks of lower intensity could not be associated at a known product of the data - bank data of JCPS [6]. 
HNF-2262 Rev, 0

\begin{tabular}{|lrlll|}
\hline Type Dos. & Aetivite & Cat MT & No doodre & Révision \\
NT & 10510 & 00 & 0004 & Rév. A \\
\hline
\end{tabular}

Page: $13 / 74$

\begin{tabular}{|c|c|c|c|c|}
\hline $\mathrm{RUN}$ & $\begin{array}{l}\text { Water } \\
\text { Pressure } \\
\text { rpat }\end{array}$ & 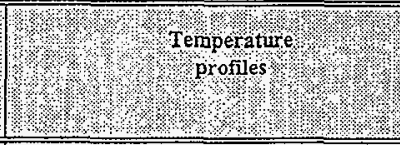 & Initial & Sample \\
\hline ES01 & 0 & $\begin{array}{l}\text { heated at constant rate of } 5^{\circ} \mathrm{C} / \mathrm{mm} \text { to a } \\
\text { temperature of about } 400^{\circ} \mathrm{C}\end{array}$ & 72.6 & 2 \\
\hline $\mathrm{ESO}_{2}$ & 5 & $\begin{array}{c}\text { heated at constant rate of } 5^{\circ} \mathrm{C} / \mathrm{mn} \text { to a } \\
\text { temperature of about } 400^{\circ} \mathrm{C}\end{array}$ & 72.4 & 2 \\
\hline $\mathrm{ESO} 3$ & 20 & $\begin{array}{l}\text { heated at constant rate of } 5^{\circ} \mathrm{C} / \mathrm{mn} \text { to a } \\
\text { temperature of about } 400^{\circ} \mathrm{C}\end{array}$ & 70.32 & 2 \\
\hline ES04 & 20 & $\begin{array}{l}\text { heated at constant rate of } 5^{\circ} \mathrm{C} / \mathrm{mm} \text { to a } \\
\text { temperature of about } 500^{\circ} \mathrm{C}\end{array}$ & 78.21 & 2 \\
\hline ESOS & 40 & $\begin{array}{l}\text { heated at constant rate of } 5^{\circ} \mathrm{C} / \mathrm{mn} \text { to a } \\
\text { temperature of about } 500^{\circ} \mathrm{C}\end{array}$ & 66.76 & -2 \\
\hline ES06 & 20 & $\begin{array}{l}\text { heated at constant rate of } 0.5^{\circ} \mathrm{C} / \mathrm{mn} \text { to a } \\
\text { temperature of about } 515^{\circ} \mathrm{C}\end{array}$ & 71.01 & 2 \\
\hline ES07 & 0 & $\begin{array}{c}\text { heated at constant rate of } 5^{\circ} \mathrm{C} / \mathrm{mn} \text { to a } \\
\text { temperature of about } 500^{\circ} \mathrm{C}\end{array}$ & 117 & 1 \\
\hline
\end{tabular}

Sample origin :

$1 \mathrm{UO} 3,2 \mathrm{H} 2 \mathrm{O}$ synthesised by immersion into water of anhydrous $\mathrm{UO} 3$

$2 \mathrm{UO}, 2 \mathrm{H} 2 \mathrm{O}$ synthesised by sweeping wet air of anhydrous $\mathrm{UO} 3$

Table 4 - Phase 2 : Experimental conditions 
HNF-2262 Rev. 0

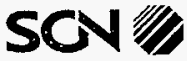

\begin{tabular}{crllr|}
\hline Type Dos. & Astivié & Cat MT & No Jordrc & Révision \\
NT. & 10510 & 00 & 0004 & Rév. A \\
\hline
\end{tabular}

Page : $14 / 74$

\begin{tabular}{|c|c|c|c|c|c|c|c|}
\hline & ESO1 & $\mathrm{ESO} 2$ & ES03 & ESO4 & ES05 & ES06 & ES07 \\
\hline \multicolumn{8}{|l|}{$\sqrt{\text { Mass Loss }}$} \\
\hline Temperature & 250 & 250 & 250 & 250 & 250 & 250 & 250 \\
\hline Absolute mass loss Percent & 7.04 & 6.62 & 7.55 & 7.34 & 6.71 & 8.04 & 35.6 \\
\hline Temperature & 400 & 400 & 400 & 400 & 400 & 400 & 400 \\
\hline Relative mass loss percent & 3.95 & 3.68 & 3.96 & 4.10 & 3.87 & 4.10 & 5.28 \\
\hline Absolute mass loss Percent & 10.71 & 10.06 & 11.21 & 11.14 & 10.32 & 11.81 & 39 \\
\hline Temperature & & & & 500 & 500 & 515 & 515 \\
\hline Relative mass loss percent & & & & 4.38 & 4.16 & 4.81 & 5.56 \\
\hline Absolute mass loss Percent & & & & 11.4 & 10.59 & 12.46 & 39.18 \\
\hline \multicolumn{8}{|l|}{ Endothermic peaks (2) } \\
\hline Peak temperature ${ }^{\circ} \mathrm{C}$ & & & & & & & $92-116$ \\
\hline Temperature range ${ }^{\circ} \mathrm{C}$ & & & & & & & $28-155$ \\
\hline Enthalpie $\quad \mathrm{J} / \mathrm{g}$ & & & & & & & 470 \\
\hline Peak temperature ${ }^{\circ} \mathrm{C}$ & 157.5 & 158 & 159 & 166 & 165 & 138 & 160 \\
\hline Temperature range ${ }^{\circ} \mathrm{C}$ & $22-210$ & $24-210$ & $24-210$ & $56-210$ & $86-210$ & $26-210$ & $28-210$ \\
\hline Enthalpie & 201 & 228 & 228 & 194 & 161 & 264 & 784 \\
\hline Peak temperature.${ }^{\circ} \mathrm{C}$ & 350 & 352 & 355 & 363 & 364 & 337 & 345 \\
\hline Temperature range ${ }^{\circ} \mathrm{C}$ & $250-405$ & $250-405$ & $250-405$ & $290-415$ & $280-420$ & $290-370$ & $280-400$ \\
\hline Enthalpie $\quad \mathrm{J} / \mathrm{g}$ & 140 & 138 & 135 & 138 & 150 & 169 & 65 \\
\hline $\begin{array}{l}\text { Enthalpie } \quad \mathrm{J} / \mathrm{g} \\
\text { (total temperature range) }\end{array}$ & $34 \mathrm{i}$ & 366 & 363 & 332 & 311 & 433 & 849 \\
\hline $\begin{array}{l}\text { DX characterisation } \\
\text { (end of runs) }\end{array}$ & amorph. & amorph. & amorph. & amorph. & amorph. & $\begin{array}{c}\mathrm{UO3} \\
\alpha\end{array}$ & amorph. \\
\hline
\end{tabular}

(1) Relative mass loss is calculated in respect with the mass sample at $250^{\circ} \mathrm{C}$

(2) The peak temperature corresponds at the maximum of peak endothermic intensity

Table 5 -Phase 2 : Experimental results 


\section{3-4 THIRD PHASE : KINETICS DATA}

Table 6 indicates the experimental conditions of the six experiments of the third phase. Three temperature have been chosen to confirm

- the reaction path

- the influence of free water at low temperatures

- the influence of water pressure at low temperatures

Appendix 3 gathers the DTG/ATD curves of this experimental phase

Table 7 summarises the results about mass loss, decomposition time and X-ray diffraction

The monohydrate are clearly identified by X-ray diffraction for runs ES08 to ES11 At the end of the run ES12 we are probably in presence of amorphous phase of UO3. This run has been made repeated, a X-ray diffraction analysis after $1 \mathrm{~h} 30 \mathrm{mn}$ of heating detected a presence of monohydrate $\mathrm{UO} 3, \mathrm{H} 2 \mathrm{O}$

The mass loss of the run ES13 is very light and the major product is the di-hydrate $\beta$ phase 
HNF-2262 Rev. 0

\begin{tabular}{|lrlll|}
\hline Type Doc. & Activité & Car NT & No dotore & Révision \\
NT & 10510 & 00 & 0004 & Rév. A \\
\hline
\end{tabular}

Page : $16 / 74$

\begin{tabular}{|c|c|c|c|c|}
\hline & $\begin{array}{l}\text { Wwater } \\
\text { Pressure } \\
\text { kpa }\end{array}$ & (1) & $\begin{array}{l}\text { Initial } \\
\text { whingight } \\
\text { mg }\end{array}$ & Sample \\
\hline ESO8 & 0 & $\begin{array}{l}\text { heated at constant rate of } 5^{\circ} \mathrm{C} / \mathrm{mn} \text { to a } \\
\text { temperature of about } 100^{\circ} \mathrm{C} \text { and plateau at this } \\
\text { temperature within weight changes is neglected }\end{array}$ & 68.48 & 2 \\
\hline ESO9 & 0 & $\begin{array}{l}\text { heated at constant rate of } 5^{\circ} \mathrm{C} / \mathrm{mn} \text { to a } \\
\text { temperature of about } 100^{\circ} \mathrm{C} \text { and plateau at this } \\
\text { temperature within weight changes is neglected }\end{array}$ & 134.9 & 1 \\
\hline ES10 & 0 & $\begin{array}{l}\text { heated at constant rate of } 5^{\circ} \mathrm{C} / \mathrm{mn} \text { to a } \\
\text { temperature of about } 75^{\circ} \mathrm{C} \text { and plateau at this } \\
\text { temperature within weight changes is neglected }\end{array}$ & 69.04 & 2 \\
\hline ESII & 0 & $\begin{array}{l}\text { heated at constant rate of } 5^{\circ} \mathrm{C} / \mathrm{mn} \text { to a } \\
\text { temperature of about } 75^{\circ} \mathrm{C} \text { and plateau at this. } \\
\text { temperature within weight changes is neglected }\end{array}$ & 159.4 & 1 \\
\hline ES12 & 0 & $\begin{array}{l}\text { heated at constant rate of } 5^{\circ} \mathrm{C} / \mathrm{mn} \text { to a } \\
\text { temperature of about } 250^{\circ} \mathrm{C} \text { and plateau at this } \\
\text { temperature within weight changes is neglected }\end{array}$ & 96.94 & 2 \\
\hline ES13 & 20 & $\begin{array}{l}\text { heated at constant rate of } 5^{\circ} \mathrm{C} / \mathrm{mn} \text { to a } \\
\text { temperature of about } 75^{\circ} \mathrm{C} \text { and plateau at this } \\
\text { temperature within weight changes is neglected }\end{array}$ & 75.82 & 2 \\
\hline
\end{tabular}

Sample origin

$1 \mathrm{UO} 3,2 \mathrm{H} 2 \mathrm{O}$ synthesised by immersion into water of anhydrous $\mathrm{UO} 3$

$2 \mathrm{UO} 3,2 \mathrm{H} 2 \mathrm{O}$ synthesised by sweeping wet air of anhydrous $\mathrm{UO}_{3}$

Table 6 - Phase 3 : Experimental conditions

\begin{tabular}{|c|c|c|c|c|c|c|}
\hline & ES08 & ESOS & ES10 & ES11 & ES12 & ES13 \\
\hline \multicolumn{7}{|l|}{$\sqrt{\text { Mass Loss }}$} \\
\hline Time & $2 \mathrm{~h} 30$ & $2 \mathrm{~h} 00$ & $7 \mathrm{~h} 00$ & Th00 & 1hoo & $3 h 00$ \\
\hline Absolute mass loss Percent & 6.96 & 34.27 & 6.06 & 27.22 & 7.46 & 0.79 \\
\hline Time & $10 \mathrm{~h} 00$ & $6 \mathrm{~h} 00$ & $17 \mathrm{~h} 00$ & $17 \mathrm{~h} 00$ & $6 \mathrm{~h} 00$ & $19 \mathrm{~h} 00$ \\
\hline Absolute mass loss Percent & 7.12 & 34.37 & 6.26 & 34.73 & 8.73 & 1.32 \\
\hline $\begin{array}{l}\text { DX characterisation } \\
1 \text { h30mn } \\
\text { (end of runs). }\end{array}$ & $\mathrm{LO} 3, \mathrm{H} 2 \mathrm{O}$ & $\mathrm{VO}_{3}, \mathrm{H} 2 \mathrm{O}$ & $\mathrm{UTO}_{3}, \mathrm{H} 2 \mathrm{O}$ & $\mathrm{UO}_{3}, \mathrm{H} 2 \mathrm{O}$ & $\begin{array}{c}\mathrm{UO} 3, \mathrm{H} 2 \mathrm{O} \\
\text { amorph.UO3 }\end{array}$ & $\mathrm{UO} 3,2 \mathrm{H} 2 \mathrm{O}$ \\
\hline
\end{tabular}

Table 7 - Phase 3 : Experimental results 
HNF-2262 Rev. 0

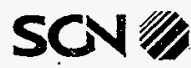

RESEAU EURISYS

\begin{tabular}{|lrlll|}
\hline $\begin{array}{l}\text { Type Doc. } \\
\text { Activité }\end{array}$ & Cat MT & \multicolumn{1}{c}{$\bar{\lambda}^{\circ}$ dotdre } & Révision \\
NT & 10510 & 00 & 0004 & Rév. A \\
\hline
\end{tabular}

Page : $17 / 74$

\section{3-4 INTERPRETATION}

\section{Reaction path}

The first plateau of the mass loss curves (ES01, ES02, ESO3 ...) cannot correspond to the monohydrate $\mathrm{UO} 2, \mathrm{H} 2 \mathrm{O}$. The theoretical mass loss is $5,6 \%$ (table 1), and experimental plateaux correspond at a mass loss between $6.6 \%$ and $8 \%$ (table 5 ).

The mass loss between the first and the second plateau is included between $3.7 \%$ and $4.1 \%$ for run ESO1 to ESO6. This result is closer to theoretical mass loss of $\mathrm{UO} 3,0.8 \mathrm{H} 2 \mathrm{O}$ than to theoretical mass loss of others hydrates.

The total mass loss, the X-diffraction analysis and the total endothermic enthalpy of run ES01 to ES06 confirm that the final product is UO3 anhydrous. The crystalline form is amorphous or $\alpha$. The mass loss curve of the run ES06 and X-ray diffraction shows that a final step of anhydrous UO3 decomposition occurs when the residence time is sufficient.

The X-diffraction analysis of the third experimental phase identified only the $\mathrm{UO} 3, \mathrm{H} 2 \mathrm{O}$ like intermediate hydrate in the decomposition process. In X-ray diffraction, patterns identified like UO3,H2O is slightly different between ESO8 and ES12 after a heating time of 1 3 $30 \mathrm{mn}$ (Appendix 10). The relative intensities of peaks is different compared with standard $\mathrm{UO} 3, \mathrm{H} 2 \mathrm{O} \mathrm{X}$-ray diffraction pattern (table 2), and the main peaks are not in the same position.

The $\mathrm{UO}_{3}, 0.8 \mathrm{H}_{2} \mathrm{O}$ hydrate is not clearly identified with $\mathrm{X}$-ray diffraction analysis but the mass loss curves show that another hydrate is involved in reaction path and the $X$-ray patterns of the various $\mathrm{UO}_{3}, \mathrm{xH}_{2} \mathrm{O}$ hydrates $(0.7<\mathrm{x}<0.9$ ) are very similar ( paragraph 21). So, the reaction path proposed is the same that Dawson [5] and Danroc [3].

$$
\begin{aligned}
& 1 \mathrm{UO}_{3}, 2 \mathrm{H}_{2} \mathrm{O} \rightarrow \mathrm{UO}_{3}, \mathrm{H}_{2} \mathrm{O}+\mathrm{H}_{2} \mathrm{O} \\
& 2 \quad \mathrm{UO}_{3}, \mathrm{H}_{2} \mathrm{O} \rightarrow \mathrm{UO}_{3}, 0.8 \mathrm{H}_{2} \mathrm{O}+0.2 \mathrm{H}_{2} \mathrm{O} \\
& 3 \quad \mathrm{UO}_{3}, 0,8 \mathrm{H}_{2} \mathrm{O} \rightarrow \mathrm{UO}_{3}(\mathrm{~mm})+0.8 \mathrm{H}_{2} \mathrm{O} \\
& 3 \mathrm{a} \\
& \mathrm{UO}_{3(\mathrm{am})} \rightarrow \mathrm{UO}_{3}(\alpha) \\
& 4 \\
& \mathrm{UO}_{3} \rightarrow 1 / 3 \mathrm{U}_{3} \mathrm{O}_{8}+1 / 6 \mathrm{O} 2
\end{aligned}
$$

For the kinetic model the step 3 a will not be taken into account. 


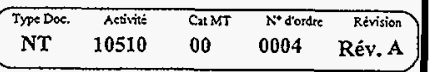

\section{Eree water}

Mass loss experimental curves of runs with the two samples (with and without free water) are presented in appendix 5 . The comparison between a runs carried out with and without free water shows that the loss of free water is faster than the loss of chemically bound water of hydrates. The loss of free water does not seem to affect the kinetic of decomposition of hydrate

\section{Water pressure}

Appendix 4 present experimental mass loss curves of nuns carried out with various atmosphere. It is not possible to conclude a consistent influence of water pressure. But the last run ESI3, carried out with a water pressure of $20 \mathrm{kPa}$, shows a very small mass loss after $19 \mathrm{~h} 00$ of heating time at $75^{\circ} \mathrm{C}(1.3 \%)$ compared to ES10 carried out with dry atmosphere $(6.26 \%)$.

Two phenomena are competing a hydrates chemical decomposition and a diffusion of water product by chemicals reactions between the sample surface (boundary layer) and the bulk atmosphere phase. The diffusion rate is proportional to water concentration. gradient between boundary layer and bulk phase. The maximum pressure in the boundary layer is determined by the equilibrium water pressure of decomposition reaction. Figure 1 shows the variation of equilibrium pressure of di-hydrate decomposition in monohydrate with thermodynamic data of [5] (Table 1). The experimental point $75^{\circ} \mathrm{C}$ and $20 \mathrm{kPa}$ (ES13) is very close to the equilibrium pressure. So the concentration gradient is small. In the runs ES04, ES05, ES06 the gradient increase like water equilibrium pressure with heating time, for this runs the diffusivity phenomena can be neglected.

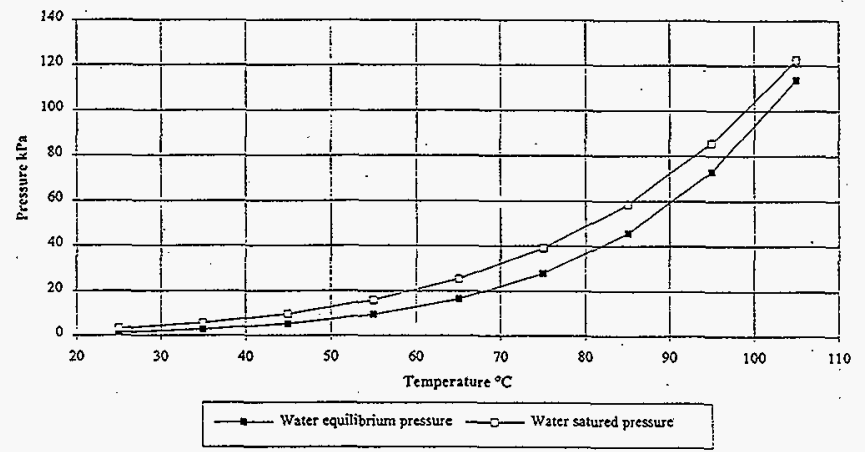

Figure 1 Water equilibrium pressure dihydrate first decomposition step 
HNF-2262 Rev. 0

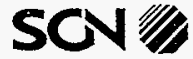

\begin{tabular}{|ccccc|}
\hline Type Dac. & Activite & Cat MT & रेंdedre & Revision \\
NT & 10510 & 00 & 0004 & Rév, A \\
\hline
\end{tabular}

RESEAU EURISTS

Page : $19 / 74$

\section{KINETIC MODEL}

\section{4-1 MODEL DESCRIPTION}

The appendix 4 presents the kinetic model. The following hypothesis have been made.

- The model is based on only on chemical kinetic laws. The model suppose that the diffusion rates is sufficiently higher than kinetic rate to allow to neglect diffusion phenomena.

- The rate of reactions does not depend on products. So, the water pressure is neglected in the kinetic law.

- The kinetic constant follows the Arhenius law.

The model is a system of differential algebraic equations. The amount of each species can be estimated with this dynamic model at each time. 


$\begin{array}{lllll}\text { NT } & 10510 & 00 & 0004 & \text { Rév. A }\end{array}$

Page : $20 / 74$

\section{4-2 DENTIFICATION METHOD}

The identification method consist to estimate the eight unknown variables which are pre-exponential factor and activation energy of each decomposition rate.

The steps of the method are the followings.

- Choice of experiment for identification. We choose runs which have been carried out with dry atmosphere, and with pure di-hydrate (ES01, ES08,ES10,ES12). The run ES06 have been used to identify the pre-exponential factor and activation energy of the last reaction of transformation of $\mathrm{UO} 3$ in $\mathrm{U} 308$.

- Acquisition of experimental data. For each runs we take into account the initial condition (mass of di-hydrate and temperature). For each acquisition time, the temperature and the mass sample is used in identification. The acquisition frequency is about a few minutes.

- Numerical resolution. A modified Gauss-Newton method is used to minimise the experimental data-model RMS deviation with respect to unknown variables. The unknown variables are reconditioned to decrease numerical convergence problems. The modification of Gauss-Newton method consists to take into account the model dynamic characteristic. A Gear method is used to solve differential algebraic system.

- Experiment-model comparison. For each run used in identification, comparison curves are drawn to compare experimental data and model estimation of mass loss.

- Influence of water pressure. The run carried out with moisture atmosphere are also used to compare experimental and model estimated mass loss. 


$\begin{array}{lllll}\text { NT } & 10510 & 00 & 0004 & \text { Rév. A }\end{array}$

Page : $21 / 74$

\section{4-3 COMPUTER MEANS}

The experimental data are ASCII files which are treated with EXCEL software [7]. The identification are carried out with Speedup software [8].

\section{4-4 RESULTS}

Table 8 shows the best fit Arrhenius parameters of model. Appendix 7 and 8 gathers comparison curves achieved with these parameters. Appendix 7 concerns runs used in parameters identification and appendix 8 runs carried out with moisture atmosphere. Appendix 9 shows the weight species variation versus time

The model can describe with very good agteement mass loss variation in thermal decomposition of pure di-hydrate in a dry atmosphere (appendix 7).

The weight species variation (appendix 9) predict that at the end of all experiment samples are constituted in majority of monohydrate (ES08 and ES10) or anhydrous UO3 (ES12, ES01). These results are in agreement with X-ray diffraction measures (table 6). The inconsistency of the model prediction concerns the run ES12 where the models predicts that the hydrates $\mathrm{UO} 3,0.8 \mathrm{H} 2 \mathrm{O}$ is preponderant after $1 \mathrm{~h} 30 \mathrm{mn}$ of thermal decomposition and the $\mathrm{X}$-ray diffraction measure identifies the monohydrate. The - literature data shows that is difficult to distinguish the different dehydrated schoepite $\mathrm{UO} 3, \mathrm{xH} 2 \mathrm{O}$ with $\mathrm{X}$-ray diffraction analysis (table 2 ).

The variation of mass loss for runs carried out in a moisture atmosphere can also been described with this model exempt for run $\operatorname{ES} 13\left(75^{\circ} \mathrm{C}, 20 \mathrm{kPa}\right)$. This results confirms that for runs ESO2 to ESO6, the heating conditions permits to neglect the diffusion phenomena.

\begin{tabular}{|l|c|c|}
\cline { 2 - 3 } \multicolumn{1}{c|}{} & $\begin{array}{c}\text { Pre-exponential } \\
\text { factor } \\
\mathrm{s}-1\end{array}$ & $\begin{array}{c}\text { Activation } \\
\text { energy } \\
\mathrm{J} / \mathrm{mol}\end{array}$ \\
\hline $\mathrm{UO} 3,2 \mathrm{H} 2 \mathrm{O}-\mathrm{H} 2 \mathrm{O}-\mathrm{UO} 3, \mathrm{UO} 3,0.8 \mathrm{H} 2 \mathrm{O}+0.2 \mathrm{H} 2 \mathrm{O}$ & $1.17 \mathrm{E}+28$ & 243456 \\
$\mathrm{UO} 3,0.8 \mathrm{H} 2 \mathrm{O}-\mathrm{UO} 3+0.8 \mathrm{H} 2 \mathrm{O}$ & 6906 & 77268 \\
$\mathrm{UO} 3-->(1 / 3) \mathrm{U} 3 \mathrm{O} 8+(2 / 6) \mathrm{O} 2$ & $1.34 \mathrm{E}-02$ & 31236 \\
\hline
\end{tabular}

Table 8 - Best-fit Arrhenius parameters 


\section{CONCLUSION}

This study has allowed to acquire a better knowledge of hydrates trioxide uranium thermal decomposition.

The main results of experimental program are:

- The thermal decomposition of dihydrate ends to anhydrous UO3 or U308, if residence time and temperature are enough. The monohydrate is identified like one of the intermediate product in the decomposition chemical path. The analysis of thermogravimetric measures shows that other chemical species seems to be involved in the decomposition chemical path

- The restrictive step in the drying process is the chemical decomposition of hydrate. The loss of free water is faster than the kinetic of decomposition

- The water pressure of the bulk atmosphere phase is a key parameter in the low temperature range. The diffusion seems to be the restrictive phenomena compared to the chemical decomposition

A kinetic model has been optimised in respect with experimental mass loss measures. This model allows to obtain decomposition rates of different species and propose a suitable reaction path.

This model will be used to choose and optimise the drying process of spent nuclear fuel. The appendix 11 shows the mass loss estimated by the model for heating conditions used in K-East canister sludge samples [10].The value of mass loss estimated does not correspond to experimental results, but the model predict with good agreement the time when the decomposition ended. These facts confirm that the chemical decomposition is the restrictive phenomena in drying process and they shows the suitable values of decomposition rates in the range of $20^{\circ} \mathrm{C}$ to $600^{\circ} \mathrm{C}$. 


\section{BIBLIOGRAPHY}

[1] HOEKSTRA H.R., SIEGEL S.

"The uranium trioxide - water system"

J. Inorg and Chem, Vol.35, pp761-779

[2] BERG L. and Col.

U3O8 oxides and UO3 hydroxide hydrates and peroxides

Gmelin handbook of inorganic chemistry

Supplementary volume part $\mathrm{C} 2$

Main serie, 8th Edition

[3] DANROC J.

"Evolution superficielle it aptitude an compactage des poudres de dioxyde d'uranium"

$\mathrm{PhD}$ Institut national polytechnique de Grenoble

[4] KUZNETSOV L.M. and TSVIGUNOV A.N.

"Effect of heat treatment on physical parametry of uranium trioxide hydrates (UO3 (1-x) $\mathrm{H} 2 \mathrm{O}^{\prime \prime}$

Radiokhimiya, vol. $25, n^{\circ} 5$, pp $652-656$

[5] DAWSON J.K., WAJT E., ALCOCK K, CHILTON D.R. "Some aspects of the system uranium trioxyde - water"

J. of chemical Society pp 3531-3540

[6] P.A.G. O'HARE P.A.G., BRETT M. LEWIS, SON N. NGUYEN "Thermochemistry of uranium compounds XVII. Standard molar enthalpy of formation at $298.15 \mathrm{~K}$ of dehydrated schoepite U03 0.9H2O.Thermodynamics of (schoepite + dehydrated schoepite+water)

J. Chem. Thermodynamic, 20, 1287-1296

[7] TAYLOR P., WOOD D.D., DUCLOS A.M., OWEN D.G. "Formation of uranium trioxide hydrates on $\mathrm{UO} 2$ fuel in air-steam mixtures near $200^{\circ} \mathrm{C} "$

Journal of Nuclear Materials $168,70-75$ 
HNF-2262 Rev. 0

\begin{tabular}{|c|c|c|c|c|}
\hline Typo Dos. & Activite & CaMT & 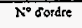 & Rérision \\
\hline NT & 10510 & 00 & 0004 & Réy, A \\
\hline
\end{tabular}

Page : $24 / 74$

[8] EXCEL software

Microsoft Exel version 4.0

(1992)

[9] SPEEDUP software

version 5.5

Aspen Technology Inc.

(1997)

[10] ABREFAH J., BUCHANAN H.C., MARSCHMAN S.C., MAKENAS B.J. "Highlight Report: Third report on drying behavior of $\mathrm{K}$-East Canister Sludge" SNFCT 97:044:R00

(1997) 
HNF-2262 Rev. 0

SCN

\begin{tabular}{|ccccc|}
\hline Type Doc. & Activite & CatMT & No dordte & Révision \\
NT & 10510 & 00 & 0004 & Rév. A \\
\hline
\end{tabular}

Page : $25 / 74$

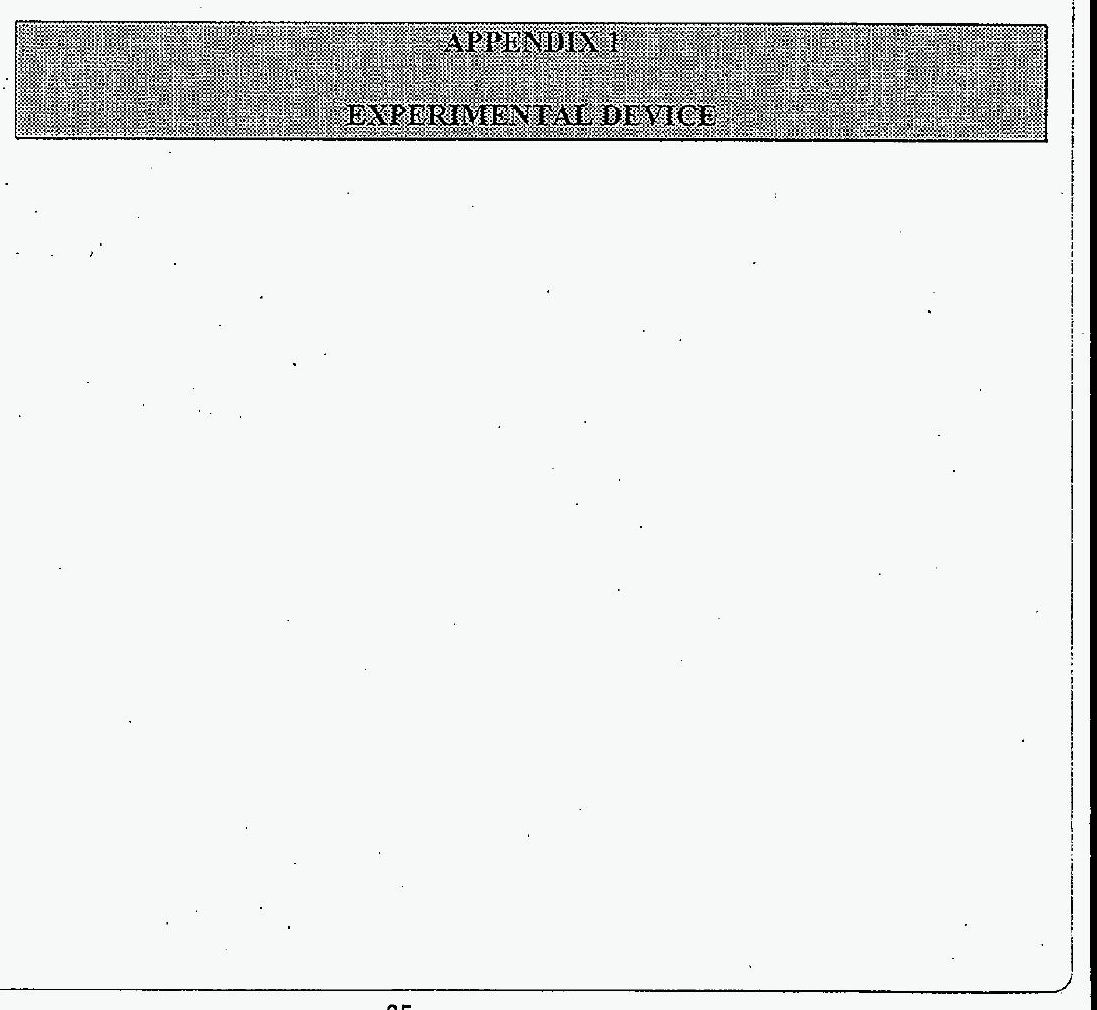




\begin{tabular}{|c|c|c|c|c|}
\hline $\begin{array}{l}\text { Type Dos } \\
\mathrm{NT}\end{array}$ & $\begin{array}{c}\text { Aesisitie } \\
10510\end{array}$ & $\begin{array}{l}\text { Cat MT } \\
00\end{array}$ & $\begin{array}{l}N^{\circ} d^{d o t} d r e \\
0004\end{array}$ & $\begin{array}{r}\text { Révision } \\
\text { Rév. A }\end{array}$ \\
\hline
\end{tabular}

Page : $26 / 74$

The experimental operating is applied for all runs of second phase and third phase and for accuracy test

\section{Experimental operating}

Place the sample into a clean tared instrument holder $(80+/ 230 \mathrm{mg})$

Sweeping with a maximum gas flow rate for $15 \mathrm{mn}$

Maintain a constant flow rate in the range from 40 to $50 \mathrm{ml} / \mathrm{mn}$

When the mass variation can be neglected $(+/-0.05 \mathrm{mg})$ the initial sample mass is recorded and the heating profile can be started. The mass loss and the heat flow between furnace and sample are recorded.

Started runs with dry gas, when saturation temperature is reached for a fixed water pressure the wet gas are send and the dry gas stopped.

When the heating profile is finished, the system is cooled at room temperature

A standard product (AL2O3) is put in place of the sample and the all precedent steps are repeated. This blank test allows to correct the base line of mass loss curve with respect of temperature evolution.

\section{Accuracy test}

The different steps are also applied at sodium oxalate for which theoretical thermal decomposition is well now with a heating rate of $5^{\circ} \mathrm{C} / \mathrm{mn}$. The accuracy of mass measurement is higher than $0.1 \mathrm{mg}$.

Sensibility coefficients for heat flow measurement have been determinate in the temperature range from 150 to $350^{\circ} \mathrm{C}$. The coefficients have been determined with known fusion enthalpies of standard metals. In the experimental temperature range the accuracy is higher than $10 \%$ of the absolute value. 
HNF-2262 Rev. 0

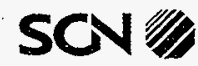

RESEAU ERRISYS

\begin{tabular}{|lrllr|}
\hline Type Doc & Activite & Cat MT & R० dordre & Révision \\
NT & 10510 & 00 & 0004 & Rév. A \\
\hline
\end{tabular}

Page : $27 / 74$

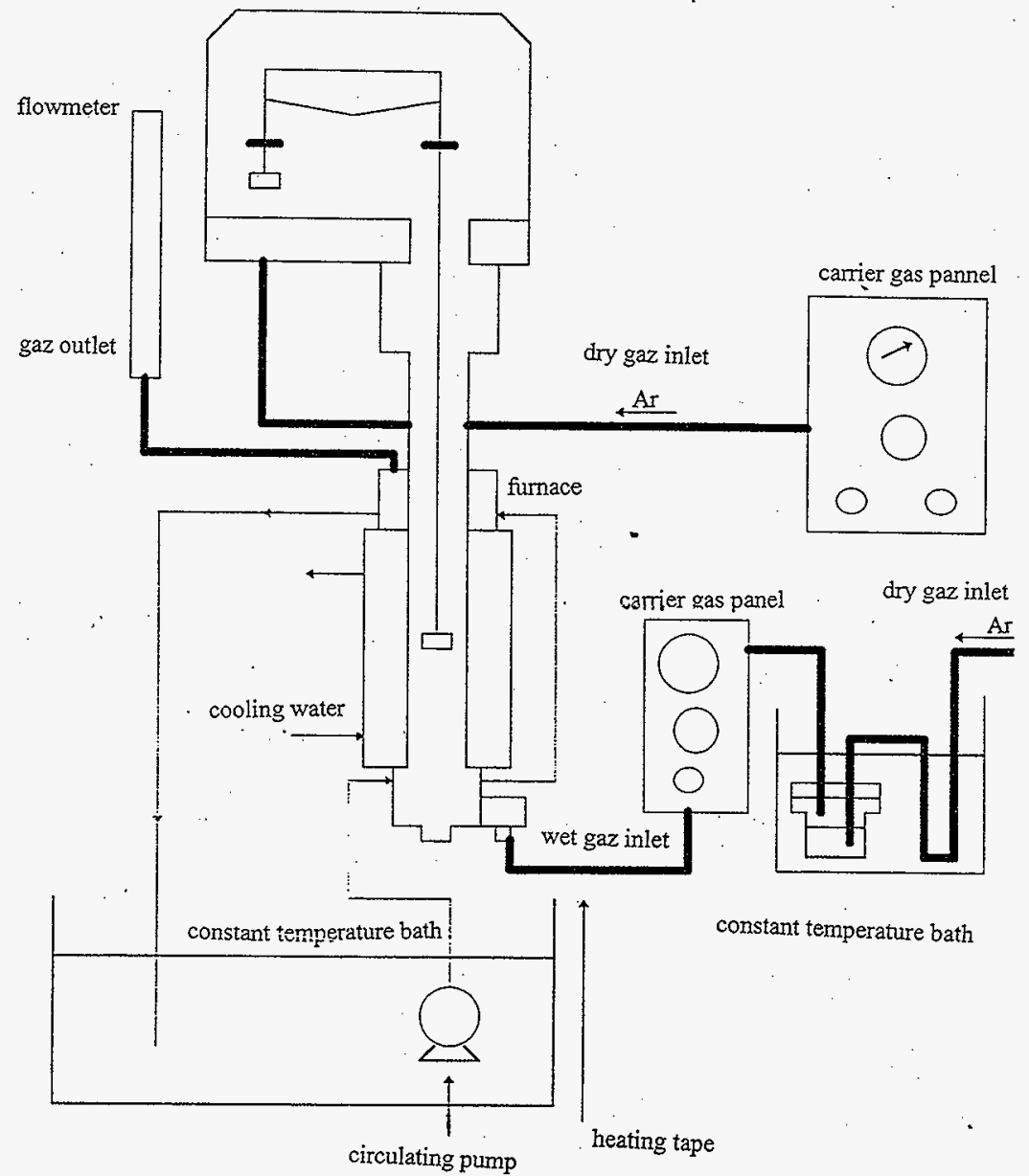


HNF-2262 Rev. 0

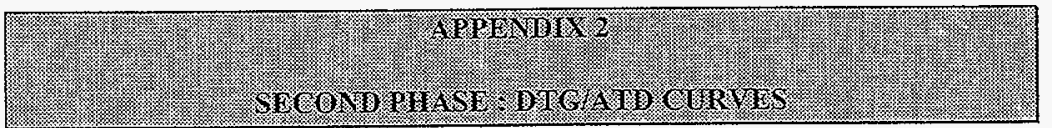


HNF-2262 Rev. 0

\begin{tabular}{|rrlll|}
\hline Type D $\alpha$ & Activite & CaMT & No fordre & Retision \\
$N T$ & 10510 & 00 & 0004 & Rév. A \\
\hline
\end{tabular}

Page : $29 / 74$

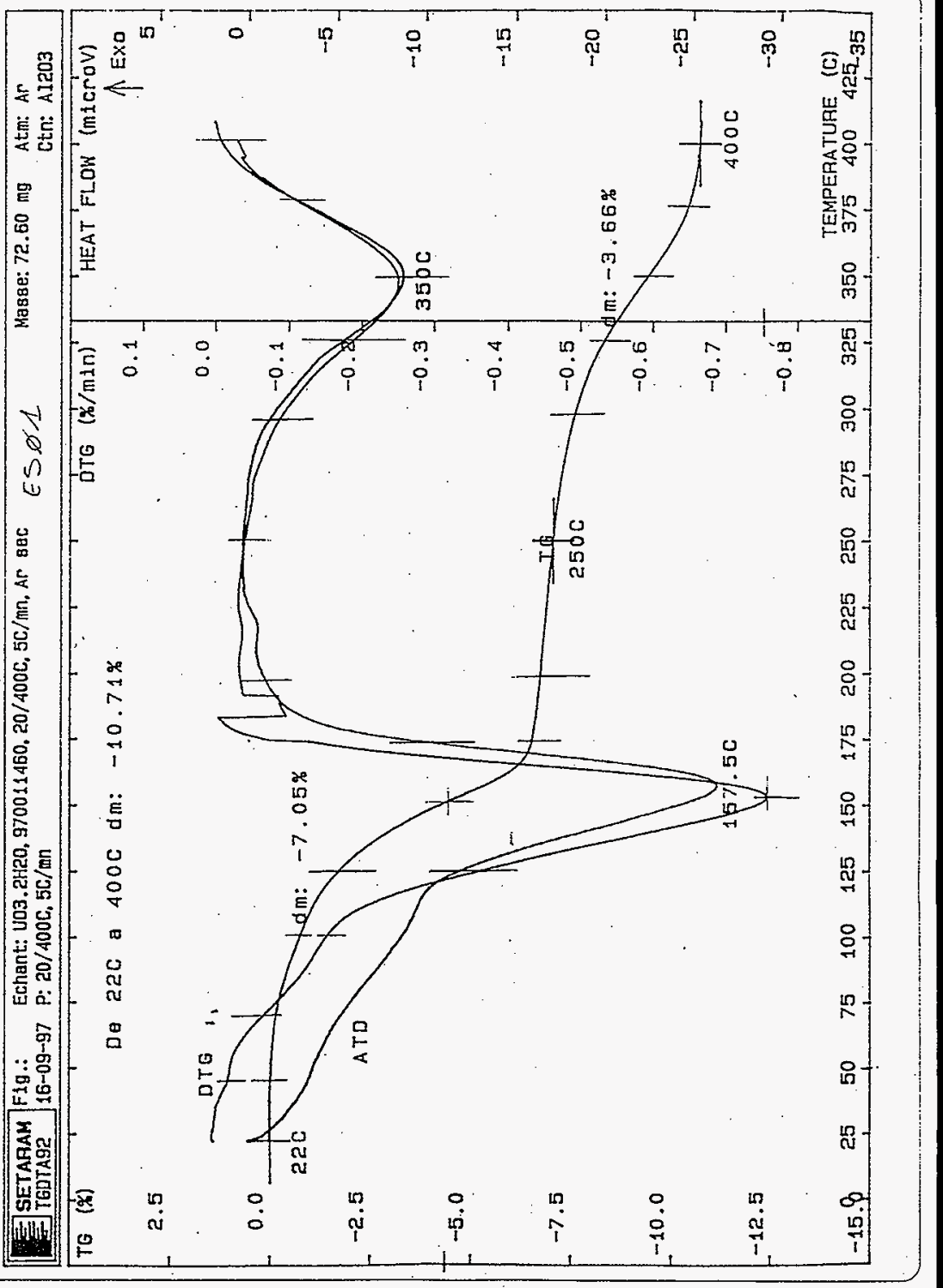


HNF-2262 Rev. 0

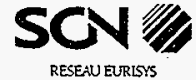

\begin{tabular}{|lrlrr|}
\hline Type Doc. & Activic & C2t MT & N॰ dordre & Révision \\
NT & 10510 & 00 & 0004 & Rév. A \\
\hline
\end{tabular}

Page : $30 / 74$

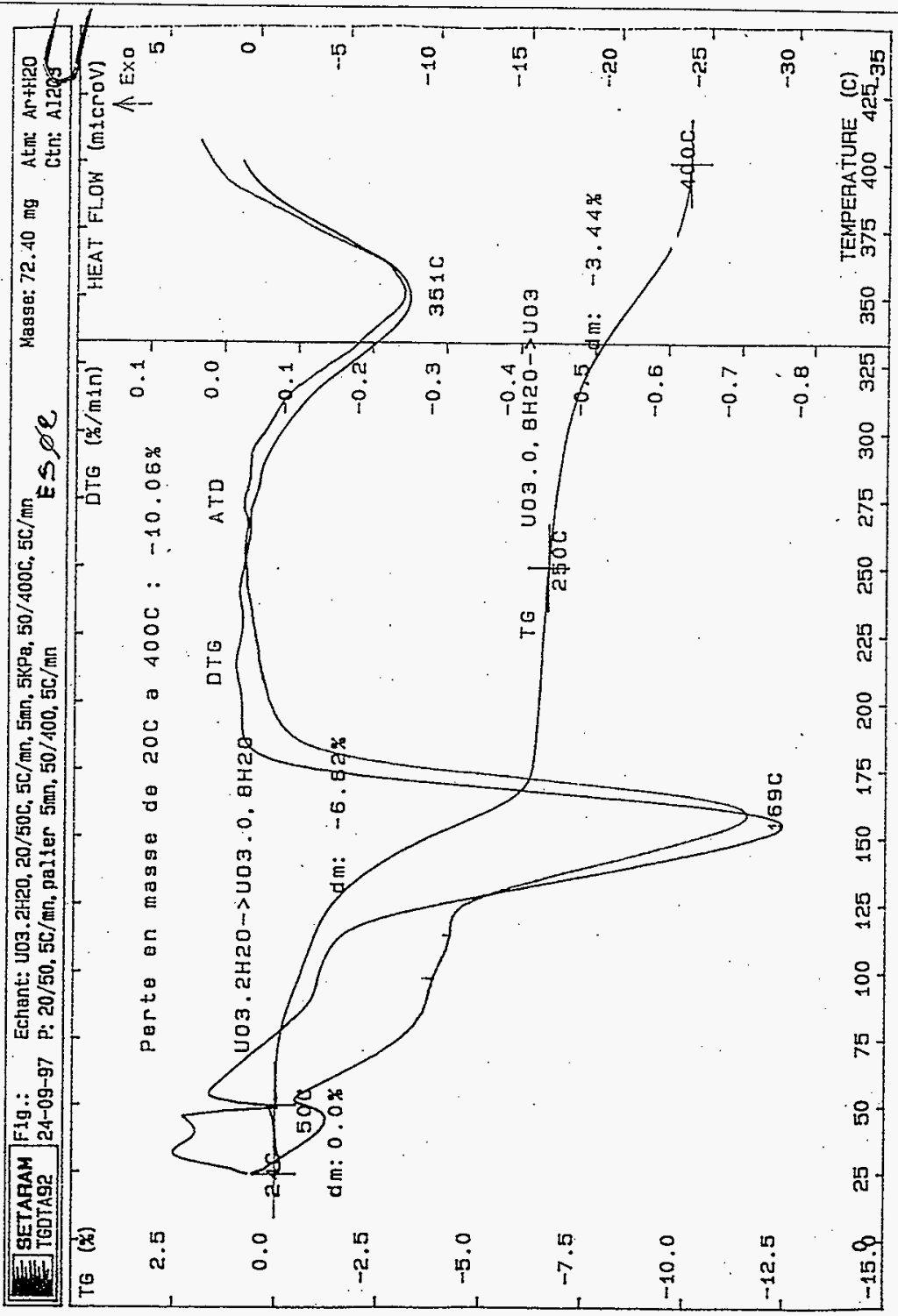






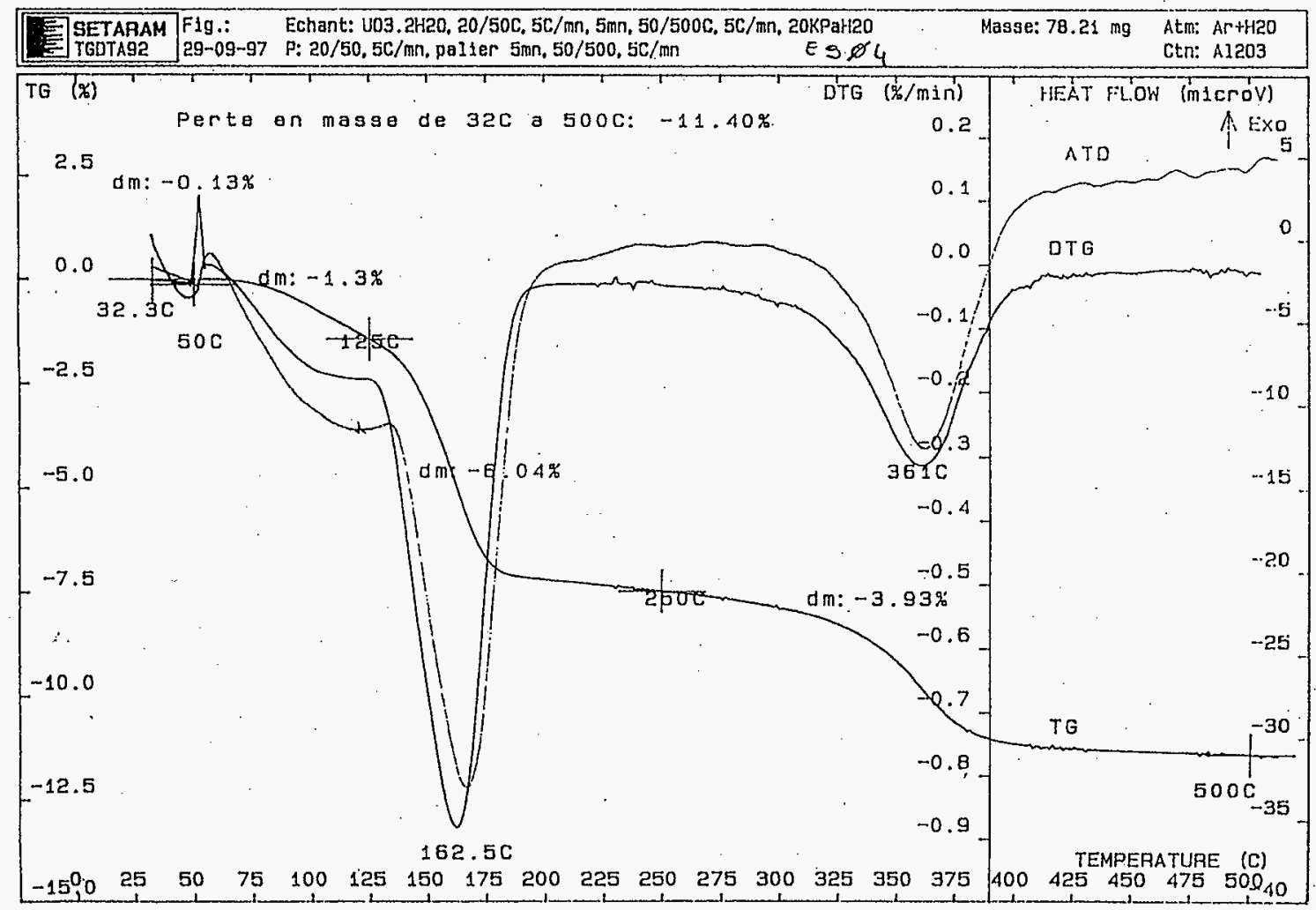



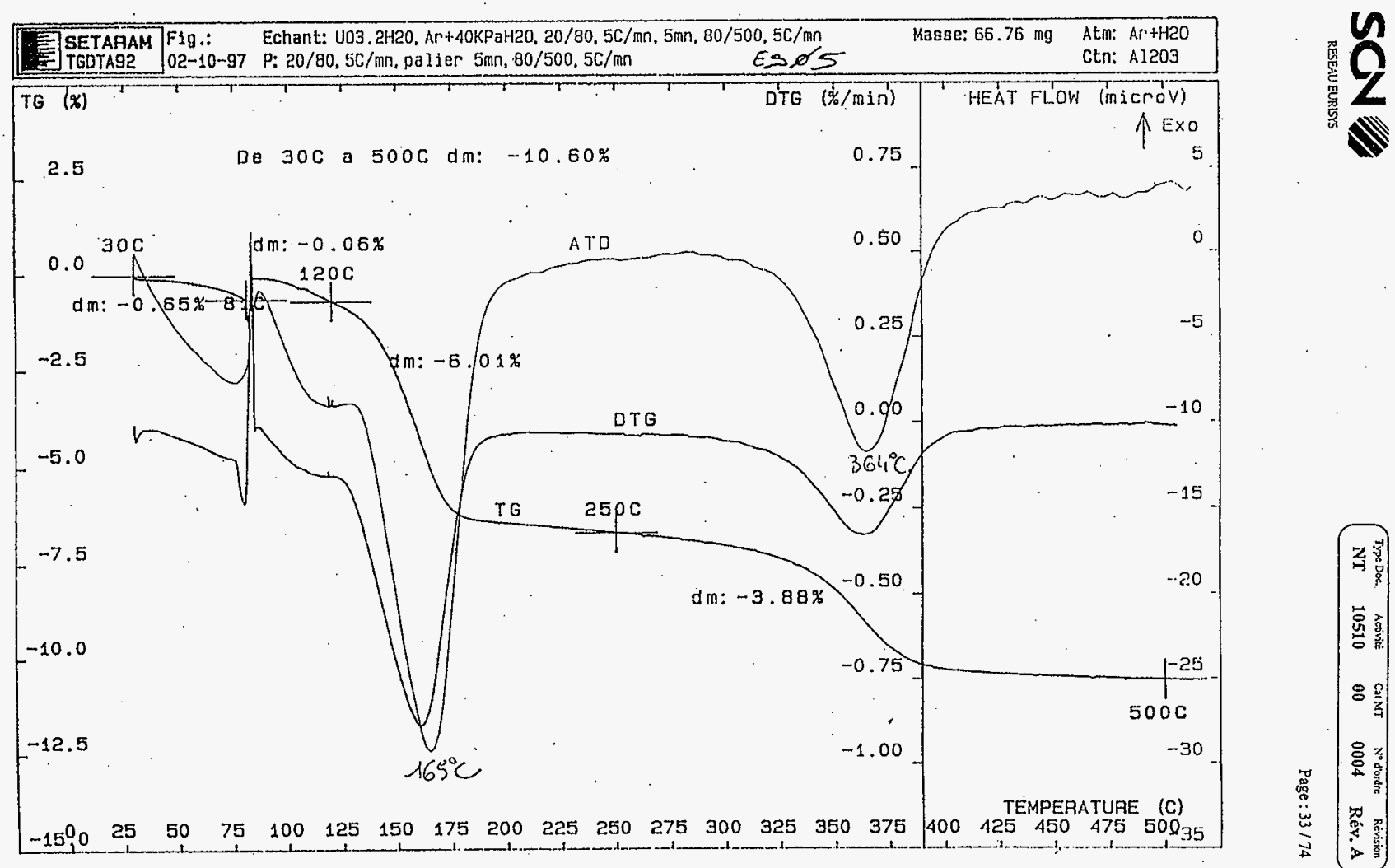
HNF-2262 Rev. 0

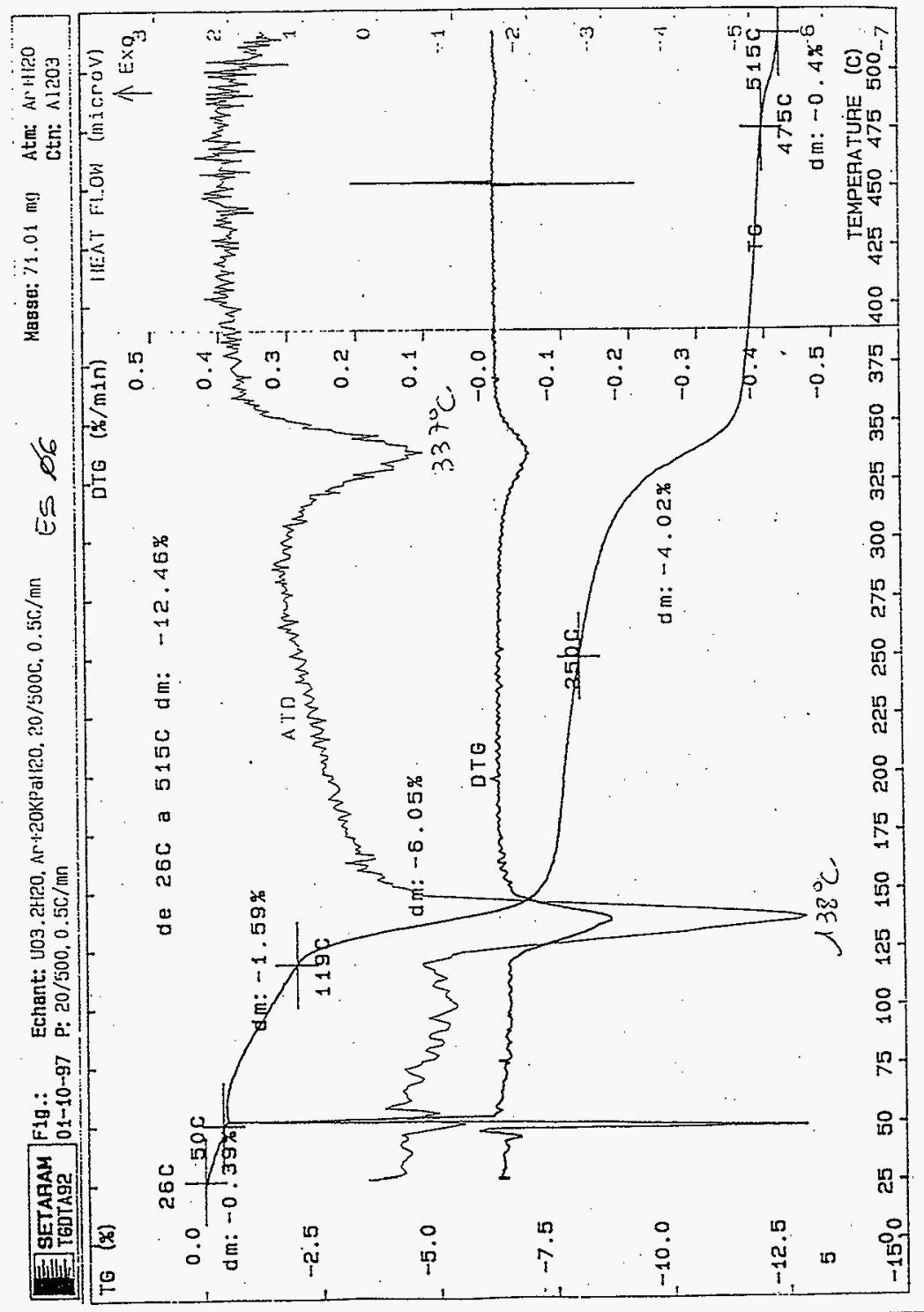


HNF-2262 Rev. 0

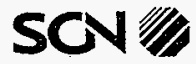

\begin{tabular}{|lrllr|}
\hline Type Doc. & Aesivie & Cat MT & No Gordse & Révision \\
NT & 10510 & 00 & 0004 & Rév. A \\
\hline
\end{tabular}

RESEAU EURLSYS

Page : $36 / 74$

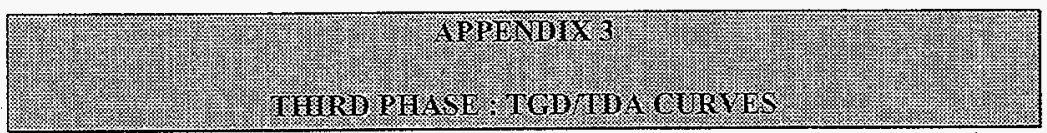


HNF-2262 Rev. 0

\begin{tabular}{|ccccc|}
\hline Yype Doc. & Activite & Cal MT & No dordre & Révision \\
NT & 10510 & 00 & 0004 & Rév. A \\
\hline
\end{tabular}

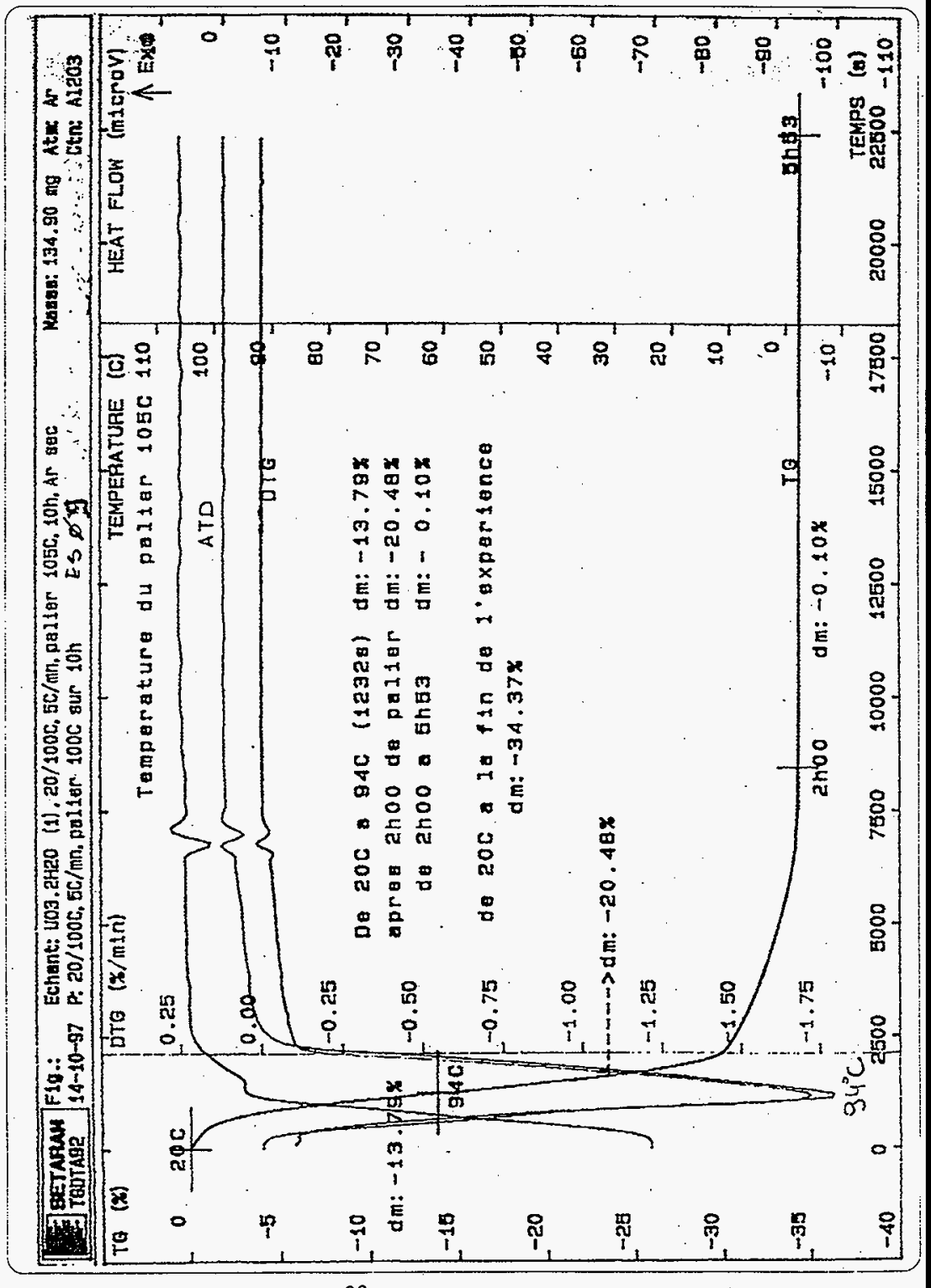


HNF-2262 Rev. 0

\begin{tabular}{|crllr|}
\hline Typs Do. & Activite & Cas MT & $N^{*}$ dordrc & Révision \\
$N T$ & 10510 & 00 & 0004 & Rév. A \\
\hline
\end{tabular}

Page : $39 / 74$

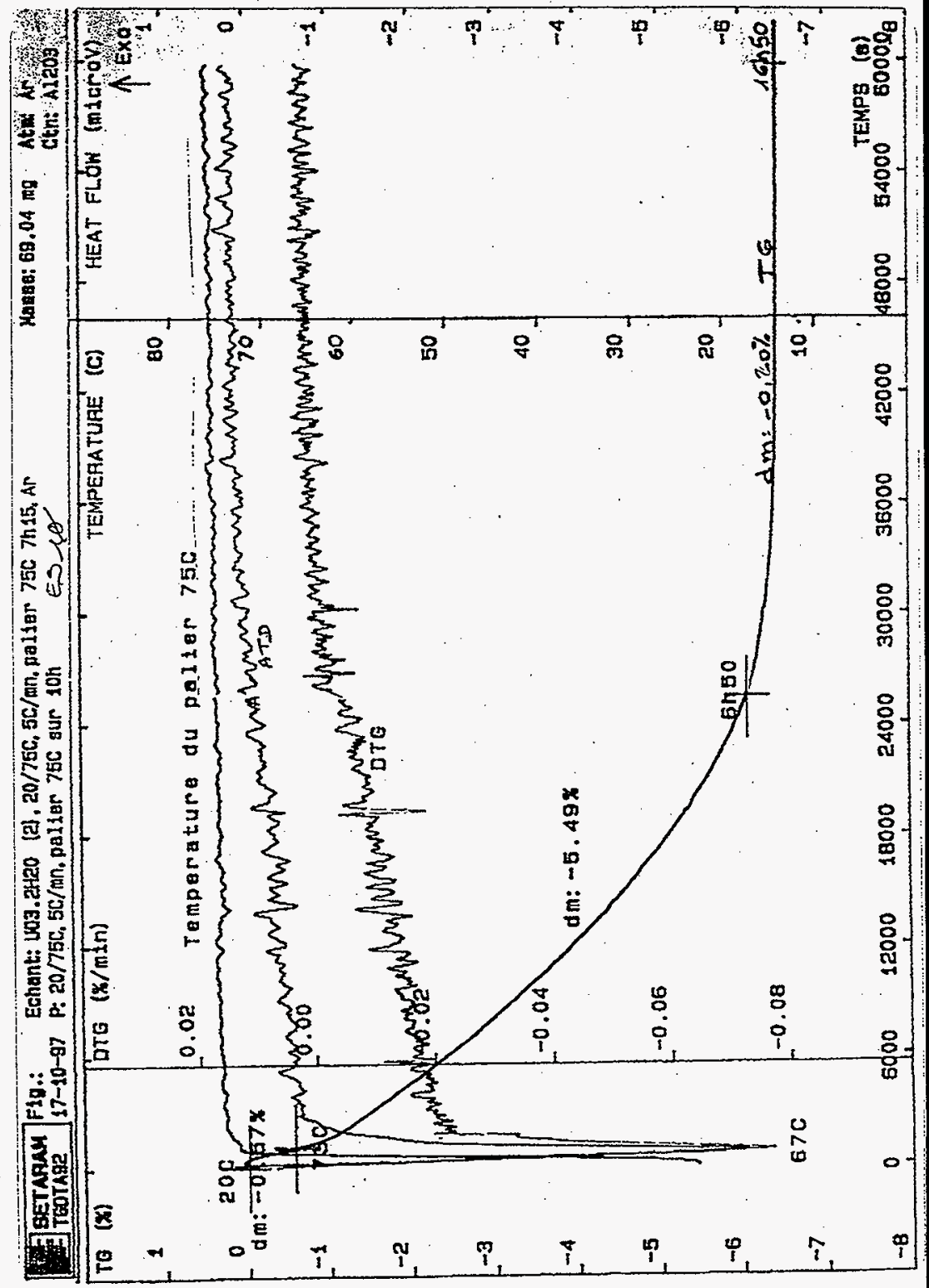


HNF-2262 Rev. 0

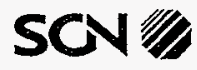

\begin{tabular}{|c|c|c|c|c|}
\hline$T_{y p c} \mathrm{D} \infty$. & Activit: & Cat MT & X'o d'ordre & Révision \\
\hline $\mathrm{NT}$ & 10510 & 00 & 0004 & Rév. A \\
\hline
\end{tabular}

RESEAU EURISYS

Page : $41 / 74$

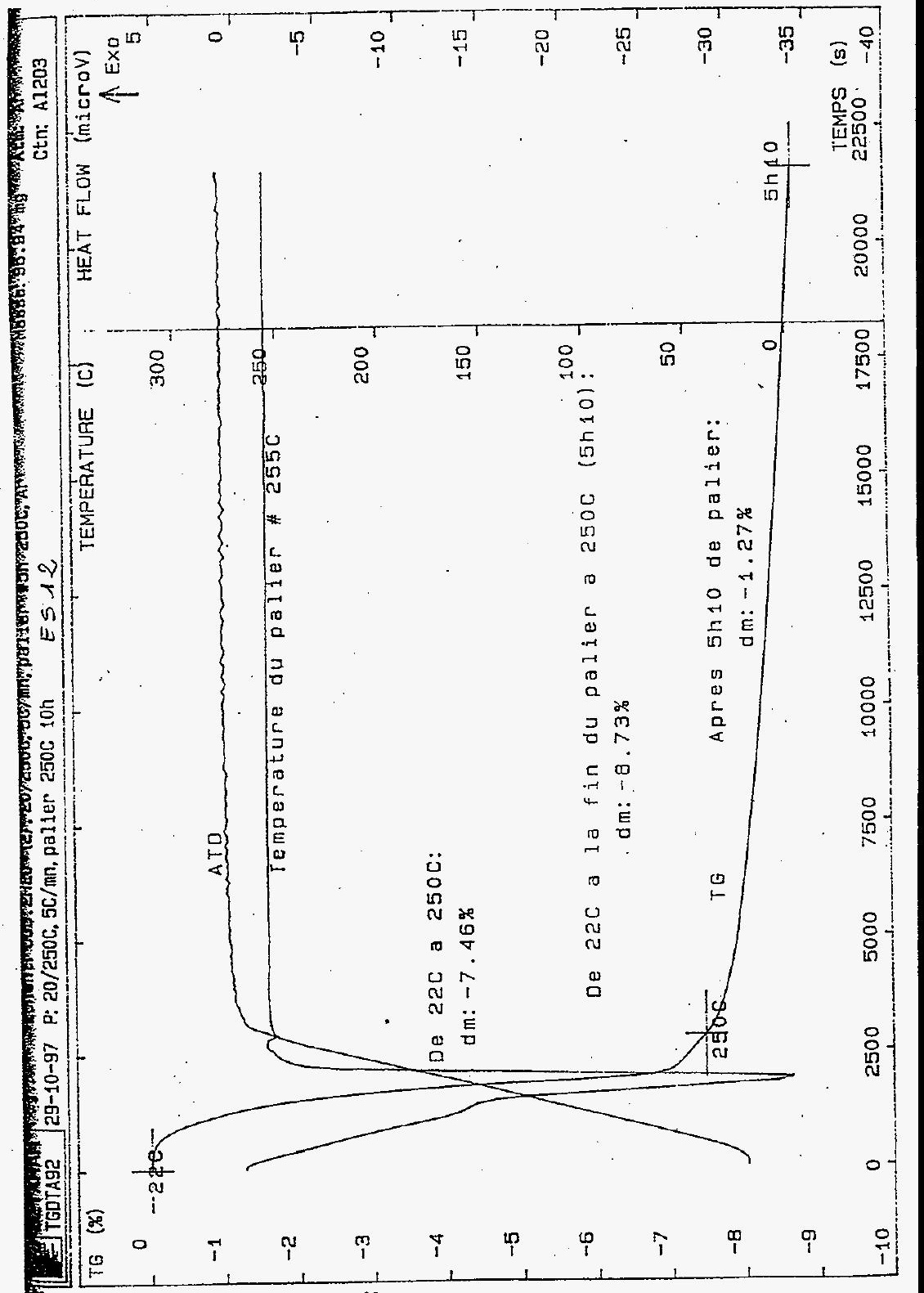


HNF-2262 Rev. 0

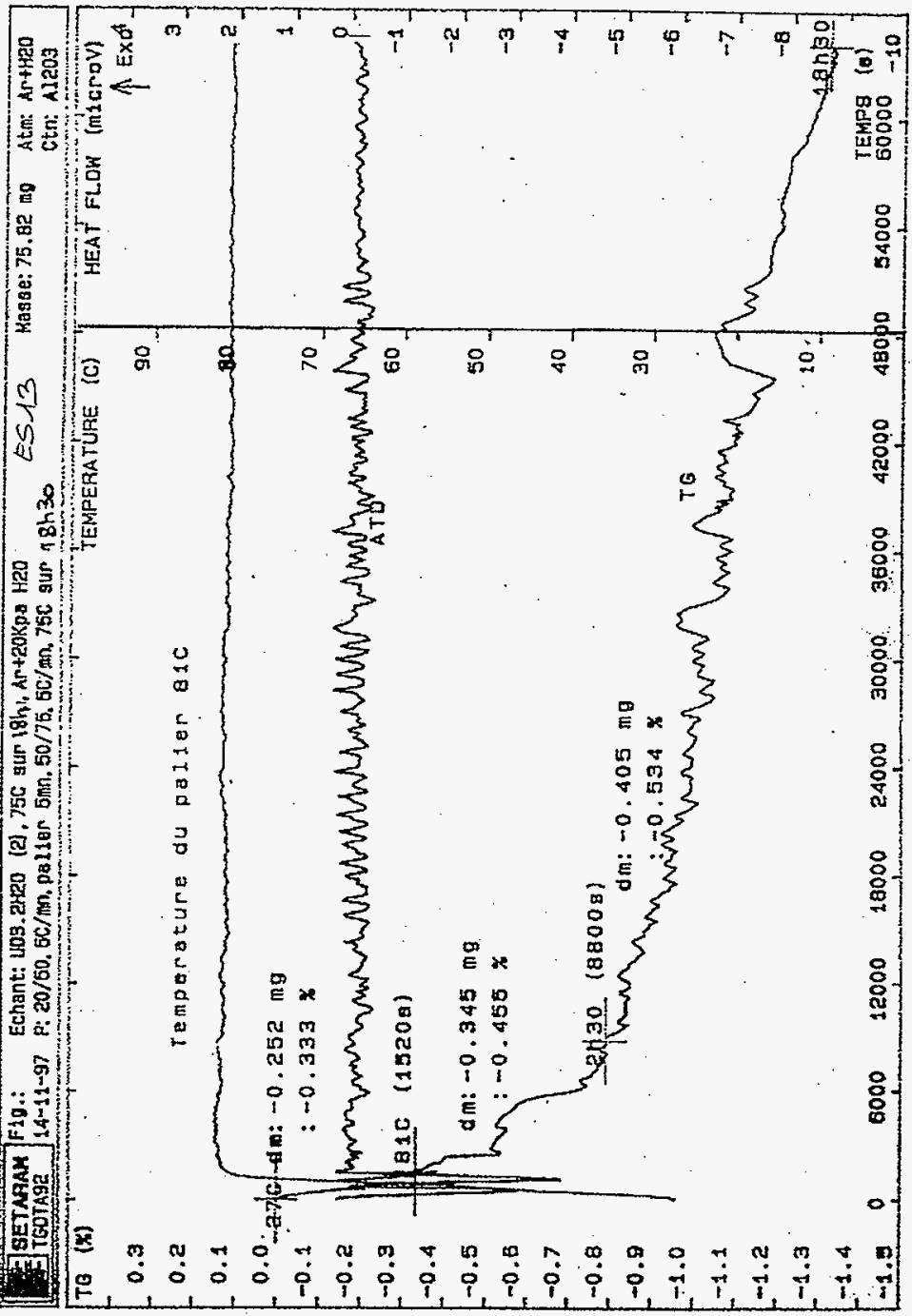


HNF-2262 Rev. 0
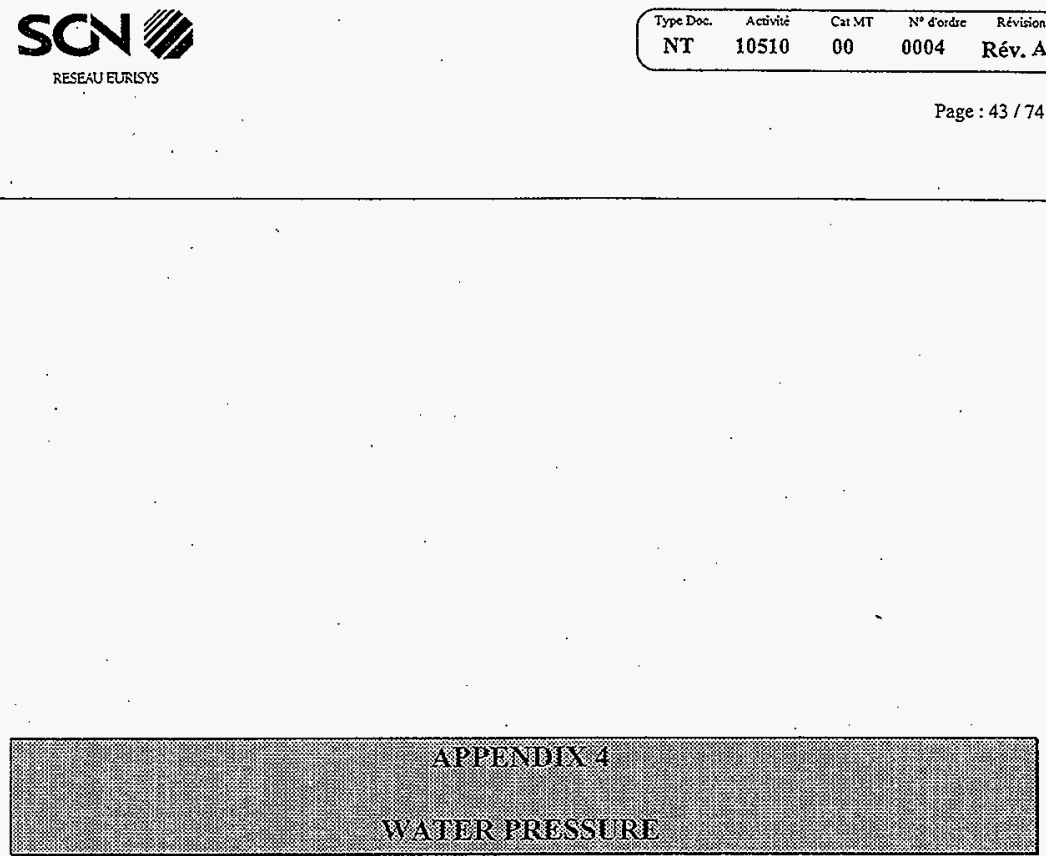

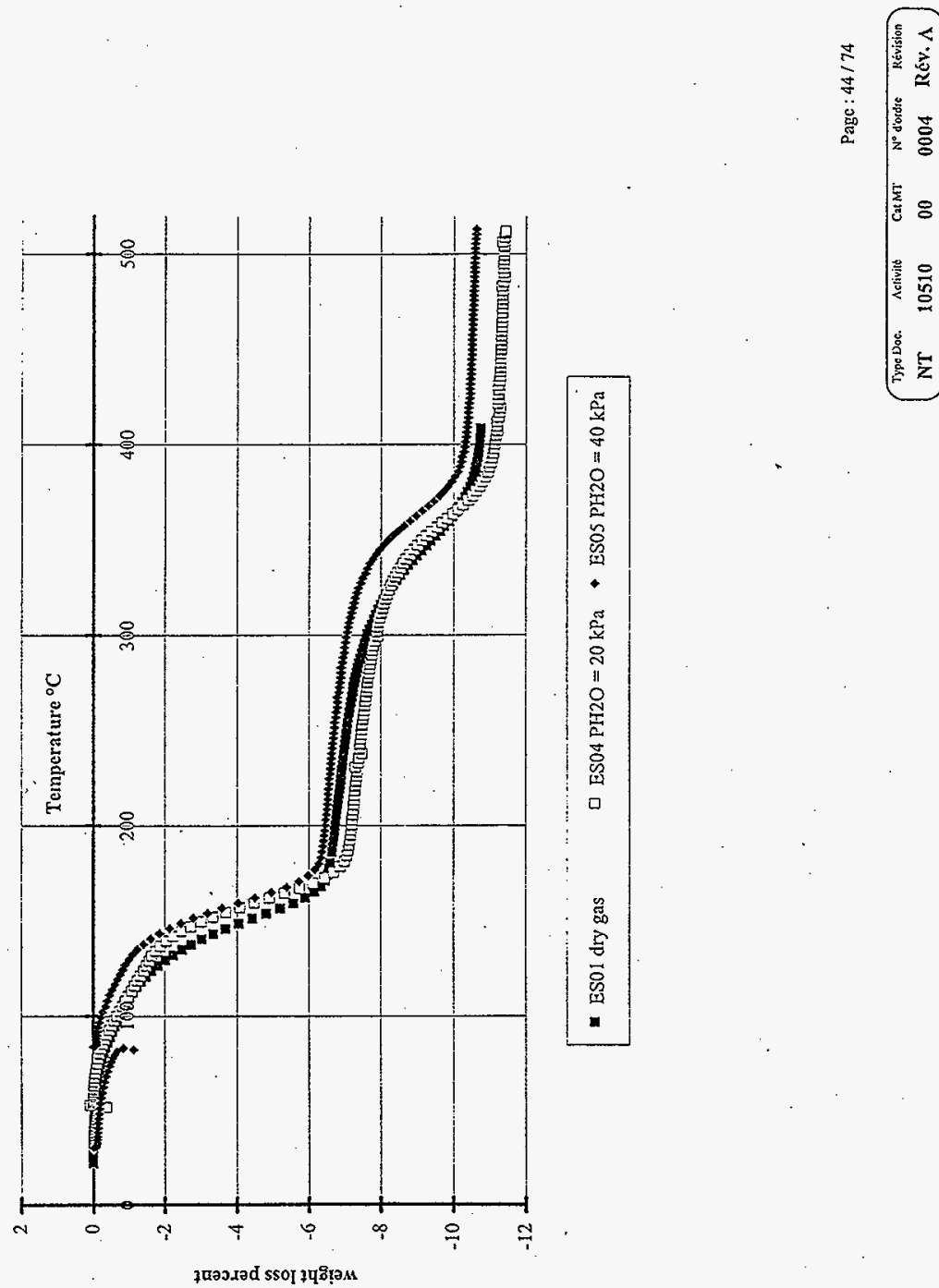
HNF-2262 Rev. 0

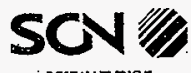

\begin{tabular}{|crlll|}
\hline Type Doc. & Activite & C2i MT & No dordé & Rétision \\
NT & 10510 & 00 & 0004 & Rév. A \\
\hline
\end{tabular}

RESEAUEURISTS

Page : $45 / 74$

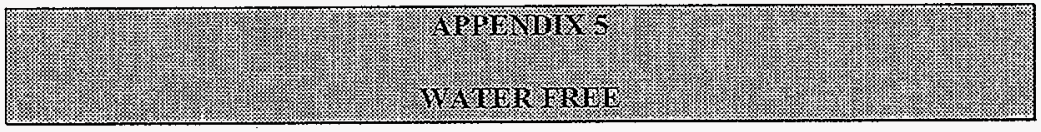



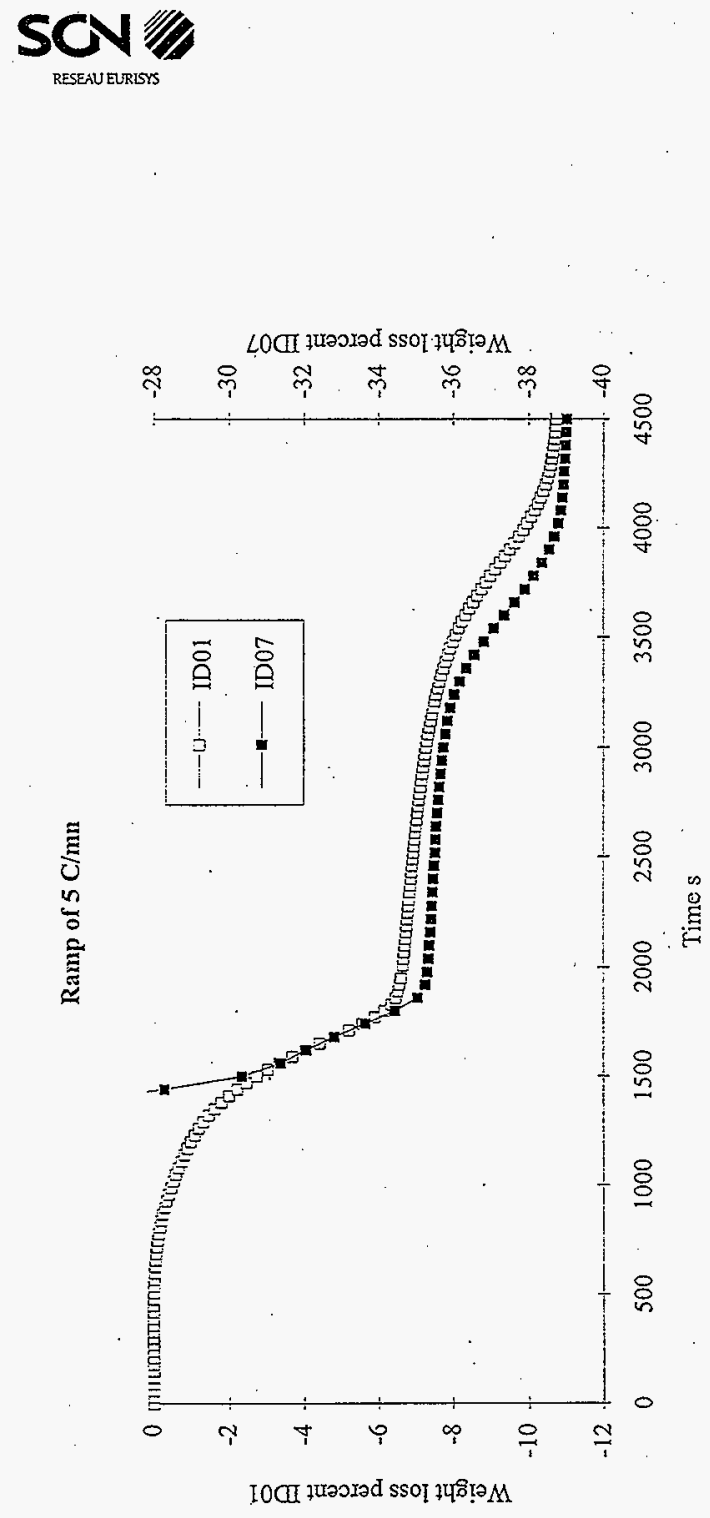

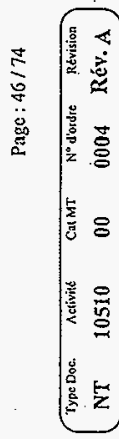




\section{SONE \\ REEEAL EURISYS}
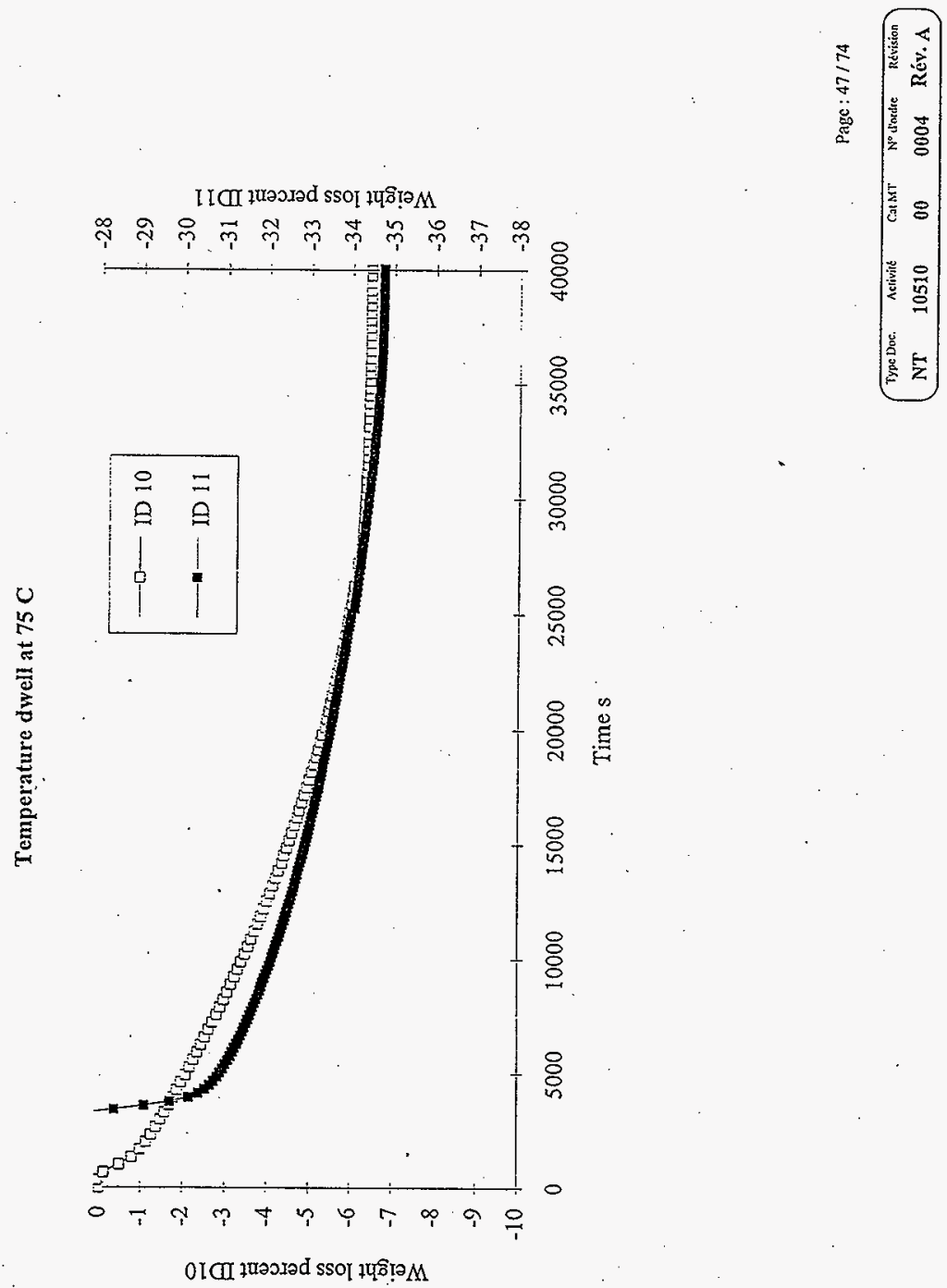

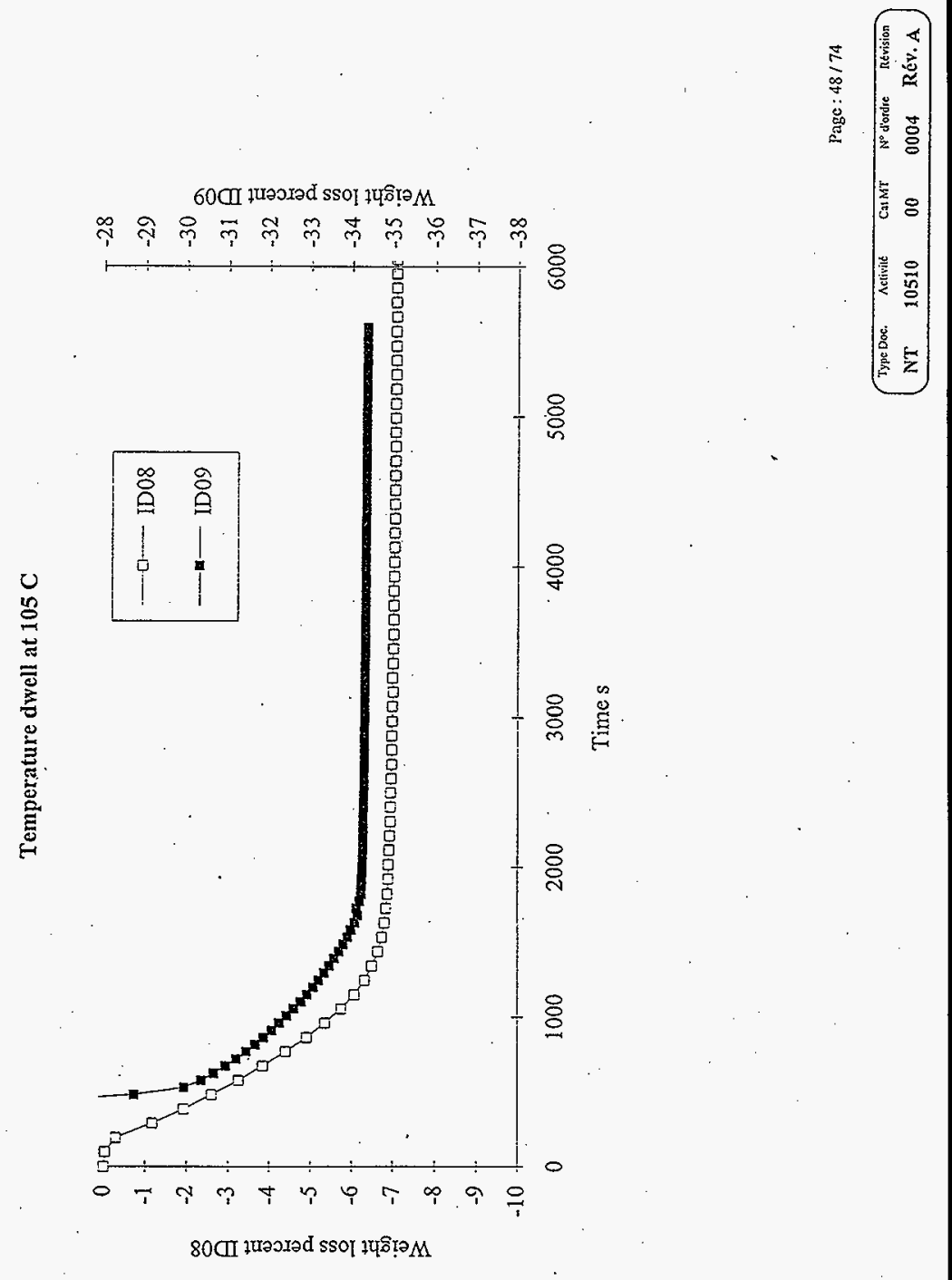

son 
HNF-2262 Rev. 0

\begin{tabular}{|c|c|c|c|c|}
\hline $\begin{array}{l}\text { Type Doc. } \\
\text { NT }\end{array}$ & $\begin{array}{l}\text { Activité } \\
10510\end{array}$ & $\begin{array}{l}\text { CatMT } \\
00\end{array}$ & $\begin{array}{l}\text { No dordre } \\
0004\end{array}$ & $\begin{array}{r}\text { Rérision } \\
\text { Réy }\end{array}$ \\
\hline
\end{tabular}

Page : $49 / 74$

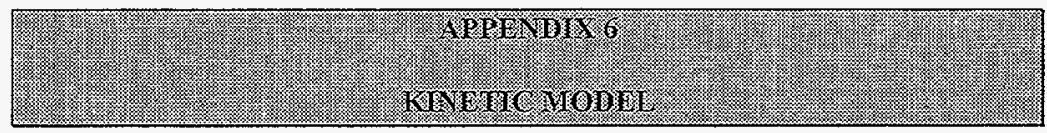


HNF-2262 Rev. 0

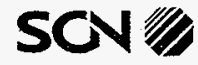

RESEAU EURLYYS

\begin{tabular}{|lrlll|}
\hline Type Doc. & Aetivite & CatMT & No d'ordre & Révision \\
NT & 10510 & 00 & 0004 & Rév. A \\
\hline
\end{tabular}

Page : $50 / 74$

Thermal decompostion of $\mathrm{UO3,2 \textrm {H } 2 \mathrm { O }}$

reactions

1. $\mathrm{UO} 3,2 \mathrm{H} 2 \mathrm{O} \rightarrow \mathrm{UO} 3, \mathrm{H} 2 \mathrm{O}+\mathrm{H} 2 \mathrm{O}$

2. $\rightarrow \mathrm{UO} 3,0.8 \mathrm{H} 2 \mathrm{O}+0.2 \mathrm{H} 2 \mathrm{O}$

3. $\rightarrow \mathrm{UO}+0.8 \mathrm{H} 2 \mathrm{O}$

4. $\quad-\rightarrow 1 / 3 \mathrm{U} 308+1 / 6 \mathrm{O} 2$

MO sample initial weight

$\mathrm{mg}$

Mt sample weight

mg

TEMP temperature

$\mathrm{K}$

Alpha_ $i$. conversion rate - reaction $n^{\circ} i$

$\mathrm{kO}$ i pre-exponential factor - reaction $n^{\circ} \mathrm{i}$

$\mathrm{k} \dot{\mathrm{i}}$ kinetic constant - reaction $\mathrm{n}^{\circ} \mathbf{i}$

$v_{i}$ reaction rate - reaction $n^{\circ} i \quad s-1$

$\overline{E a}$ i activation energy - reaction $n^{\circ} i \quad J / m o l$

MMeau Molar weight of water. MMeau $=18 \mathrm{~g} / \mathrm{mol}$

MMdihy Molar weight of UO3,2H2O MMdihy $=322 \mathrm{~g} / \mathrm{mol}$

MMU3O8 Molar weight of U308 MMU3O8 $=842 \mathrm{~g} / \mathrm{mol}$

Pourcent Weight Ioss percent

M_HYD2 Weight of UO3,2H2O mg

M_FYD1 Weight of UO3, $\mathrm{H2O} \mathrm{mg}$

M_HYD08 Weight of UO3, $0.8 \mathrm{H} 2 \mathrm{O} \mathrm{mg}$

M_U3O8 Weight of $\mathrm{U} 308 \mathrm{mg}$

M_UO3 Weight of $\mathrm{UO}$. mg

$\mathrm{dX} / \mathrm{dt} \quad$ time differential of $\mathrm{X}$ 
HNF-2262 Rev. 0

\begin{tabular}{|crlll|}
\hline Type Doc: & Activite & CathT & $\aleph^{\circ 0}$ dotdre & Revision \\
NT & 10510 & 00 & 0004 & Rév. A \\
\hline
\end{tabular}

\section{Equations}

Kinetic

$\mathrm{v}_{1} 1=\mathrm{k}_{1} 1 *(1-$ Alpha 1$)$

$v_{-} 2=\mathrm{k} 2 *$ (Alpha_1-Alpha_2)

$v_{-} 3=\mathrm{k} 3 *$ (Alpha_2-Alpha_3)

$\mathrm{v} \_4=\mathrm{k}_{-} 4 *($ Alpha_3-Alpha_4)

dAlpha $1 / d t=v_{1} 1$

dAlpha $2 / d t=v 22$

dAlpha_3/dt $=v_{-} 3$

dAlpha_ $4 / d t=v_{-} 4$

$\left(\log (k+1)-\log \left(k 0 \_1\right)\right)=E a \_1 /\left(R^{*}\right.$ TEMP $)$

$\left(\log \left(\mathrm{k} \_2\right)-\log \left(\mathrm{kO} \_2\right)\right)=\mathrm{Ea} \_2 /(\mathrm{R} * \mathrm{TEMP})$

$\left(\log \left(\mathrm{k}_{-} 3\right)-\log \left(\mathrm{kO}_{-} 3\right)\right)=\mathrm{Ea} \_3 /(\mathrm{R} * \mathrm{TEMP})$

$\left(\log \left(k_{-} 4\right)-\log \left(\mathrm{kO}_{-} 4\right)\right)=\mathrm{Ea} 4 /(\mathrm{R} * \mathrm{TEMP})$

Mass balance

$$
\begin{aligned}
& \mathrm{r} 1 * \text { MMdihy }=\text { MMeau } \\
& \mathrm{r} 2 * \text { MMdihy }=\text { MMU3O8 }
\end{aligned}
$$

- pourcent $* \mathrm{m0}=-100 *(\mathrm{m0}-\mathrm{Mt})$

$\mathrm{Mt}=\mathrm{M} \_$HYD $2+\mathrm{M} \_$HYD $1+\mathrm{M} \_H Y D 08+\mathrm{M} \_\mathrm{UO} 3+\mathrm{M}$ _U308

M_HYD2 $=m 0 *(1-$ Alpha_ 1$)$

M HYD1 $=\mathrm{mo}^{*}$ (Alpha_1-Alpha_2 $*(1-\mathrm{r} 1)$

M_HYDO8 $=\mathrm{mo} *($ Alpha_2-Alpha_3 $) *(1-1.2 * \mathrm{rl})$

$\mathrm{MLUO3}=\mathrm{mo} *($ Alpha_3-Alpha_4 $) *(1-2 * \mathrm{ri})$

$\mathrm{M} \_\mathrm{U} 3 \mathrm{O} 8=\mathrm{m} 0 *$ Alpha_ $4 * 2 / 3$ 
HNF-2262 Rev. 0

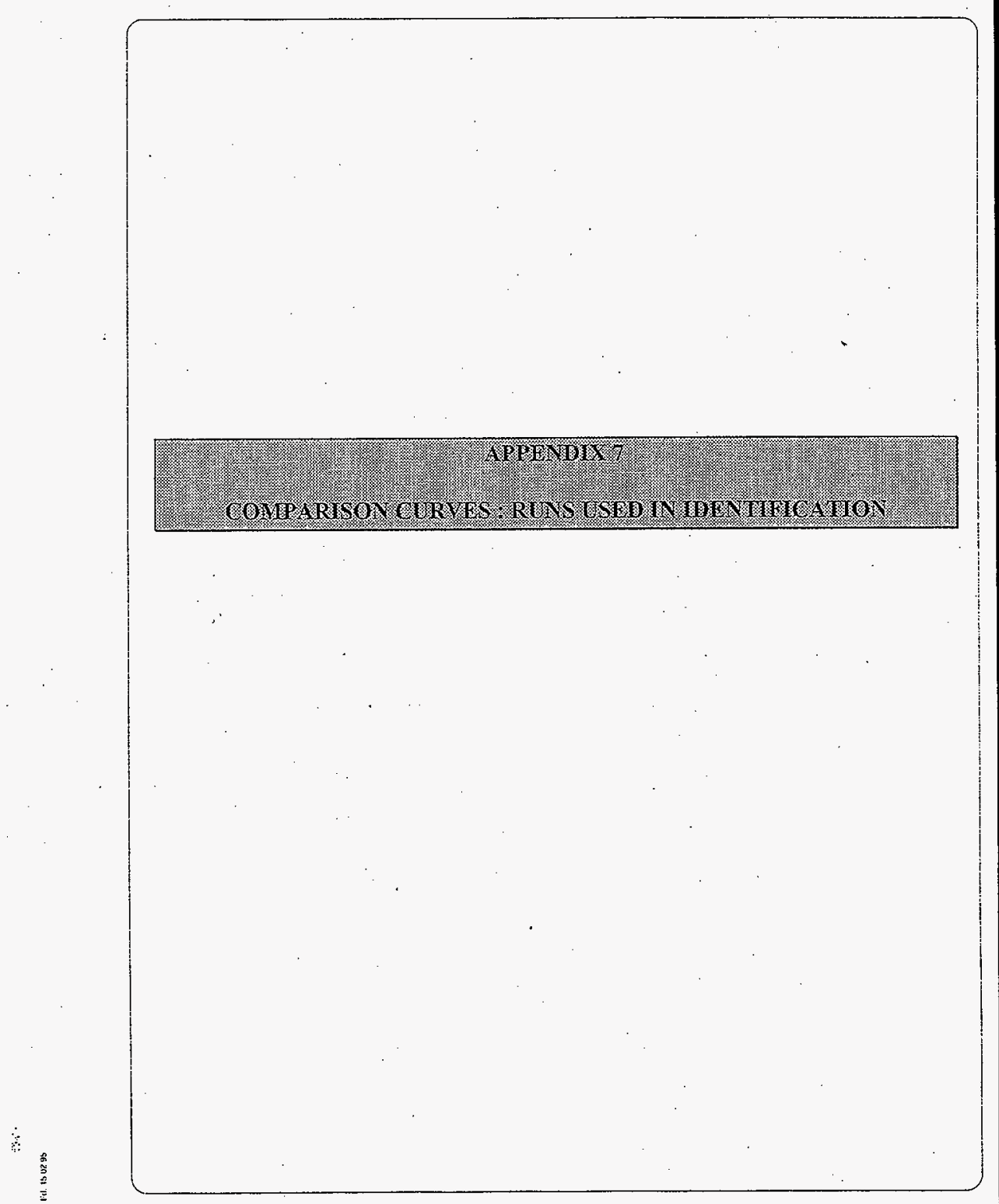


HNF-2262 Rev. 0

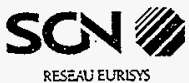

\begin{tabular}{|cclcr|}
\hline Type Doc. & Activite & Czt MT & N* d'ordre & Révision \\
NT & 10510 & 00 & 0004 & Rév. A \\
\hline
\end{tabular}

\begin{tabular}{l}
\multirow{5}{0}{} \\
0 \\
$\frac{1}{0}$ \\
5 \\
0 \\
0 \\
5 \\
5 \\
5 \\
5
\end{tabular}

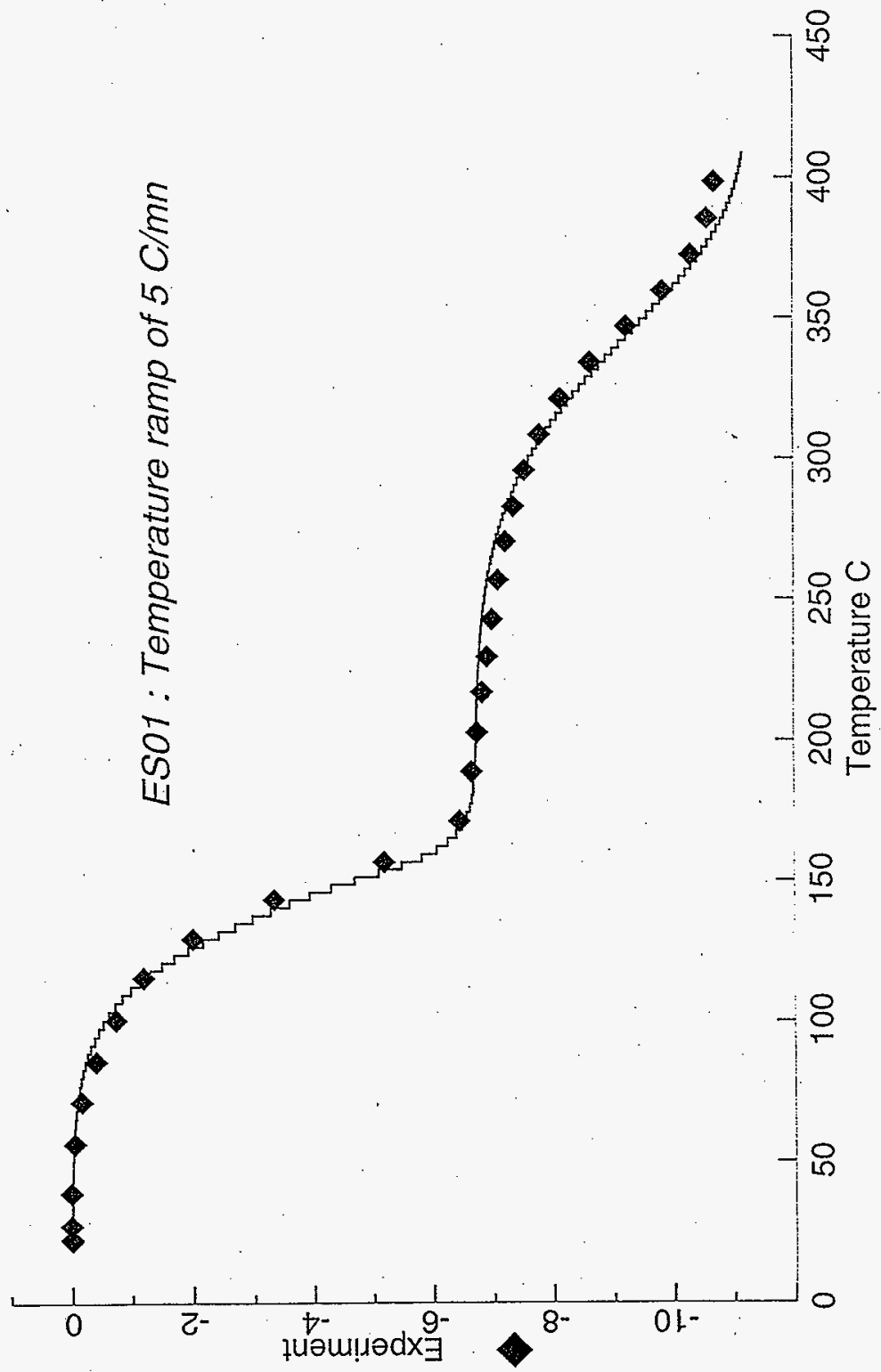


HNF-2262 Rev. 0

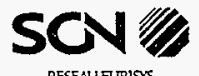

Page : $54 / 74$

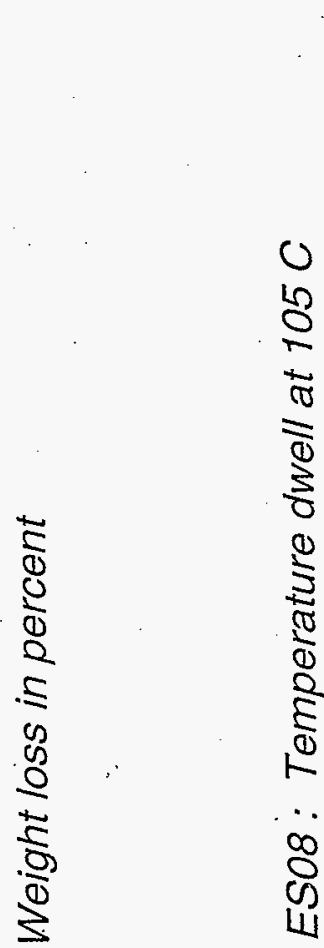

0
0
$\frac{1}{2}$
$\frac{\pi}{2}$
$\frac{1}{0}$

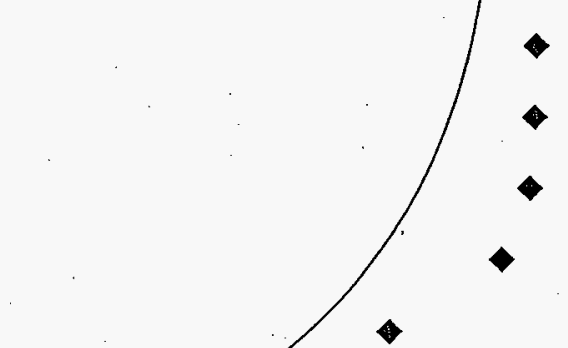$$
\text { - } 8
$$$$
\left\{\begin{array}{l}
8 \\
8 \\
0
\end{array}\right.
$$$$
\text { . }
$$$$
+8
$$

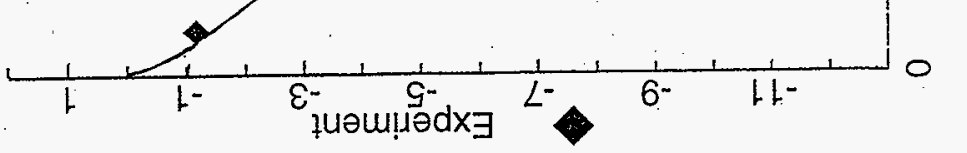


HNF-2262 Rev. 0

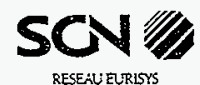

\begin{tabular}{|c|c|c|c|c|}
\hline TypeDac. & Activit: & CatMI & $N^{\circ}$ dordse & Resision \\
\hline NT & 10510 & 00 & 0004 & Rév, A \\
\hline
\end{tabular}

RESEAUEURISYS

Page : $55 / 74$

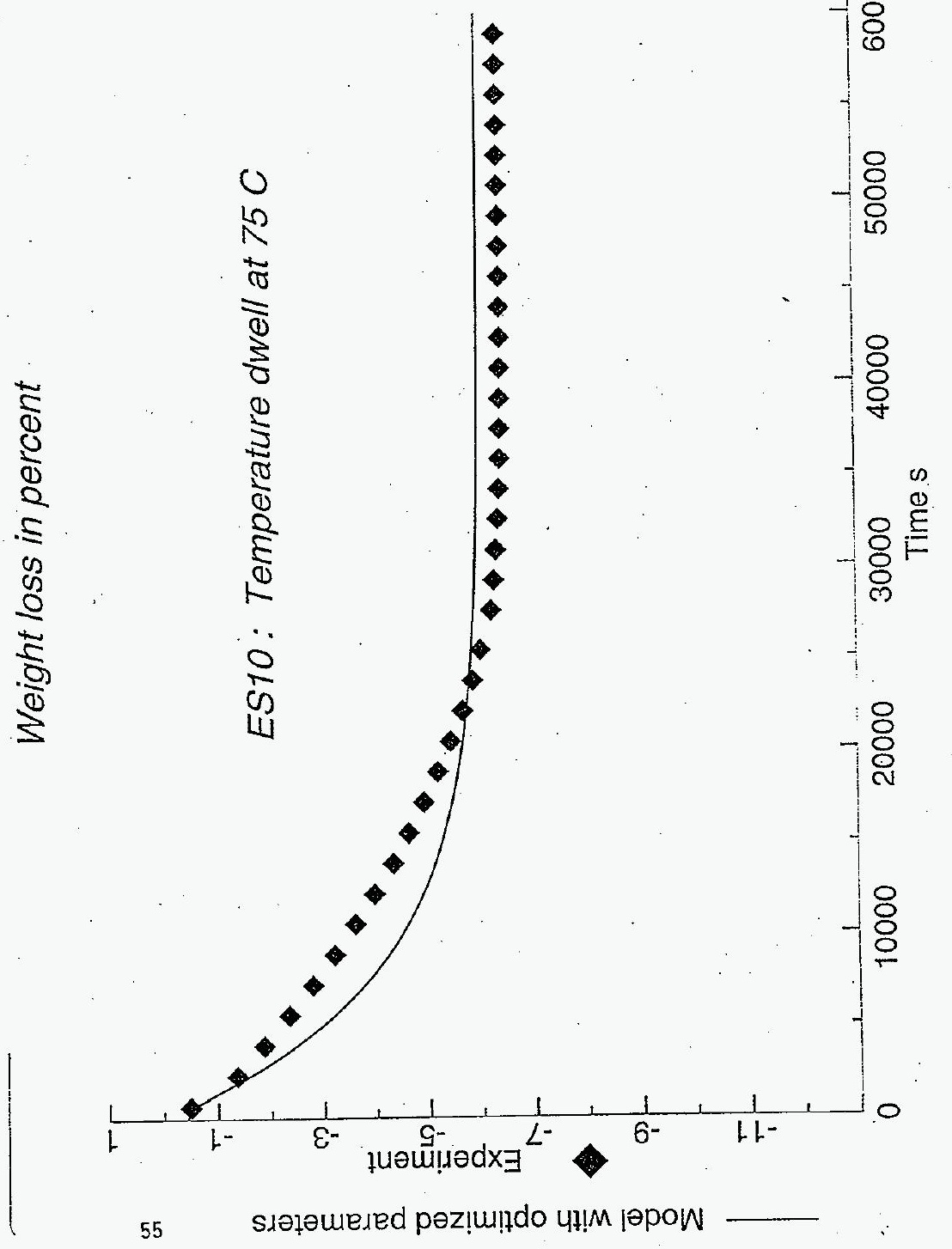


HNF-2262 Rev. 0

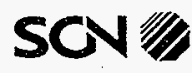

RESEAU EURLSTS

\begin{tabular}{|c|c|c|c|c|}
\hline Type Doc. & Activicé & Cat MT & $\mathrm{N}^{\circ}$ deodre & Révision \\
\hline NT & 10510 & 00 & 0004 & Rév. A \\
\hline
\end{tabular}

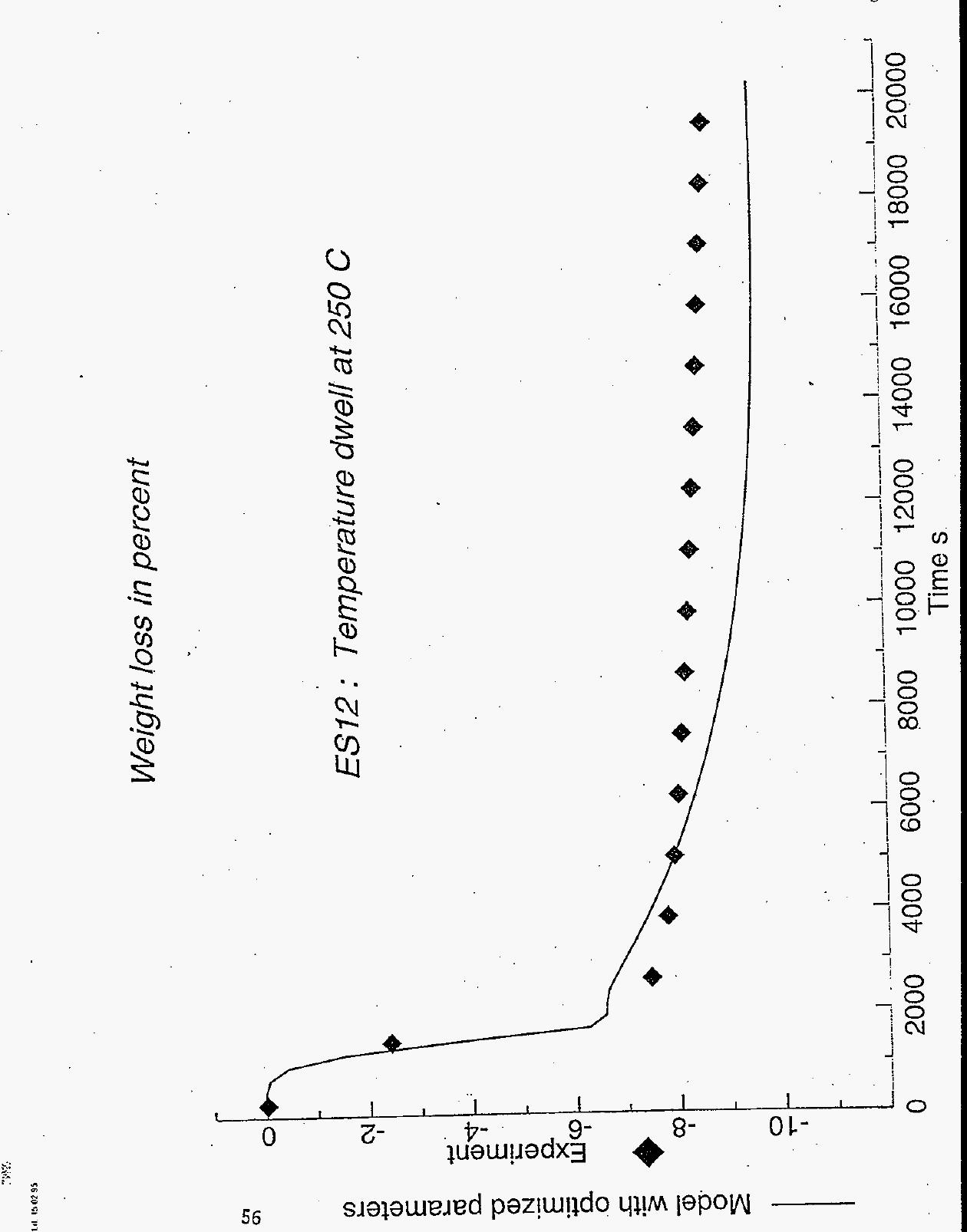

Page : $56 / 74$ 
HNF-2262 Rev. 0

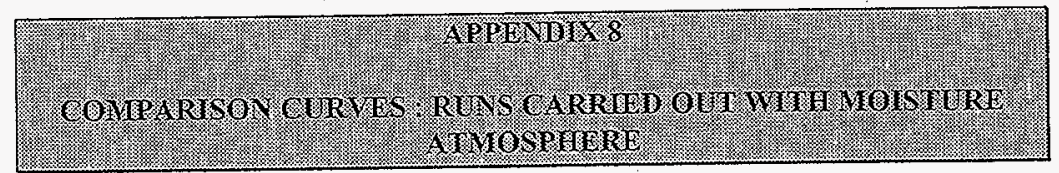


HNF-2262 Rev. 0

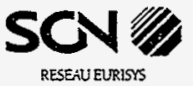

\begin{tabular}{|lllll|}
\hline Type Dse. & Activite & Cat MT & N. dordte $^{*}$ & Révision \\
NT & 10510 & 00 & 0004 & Rév. A \\
\hline
\end{tabular}

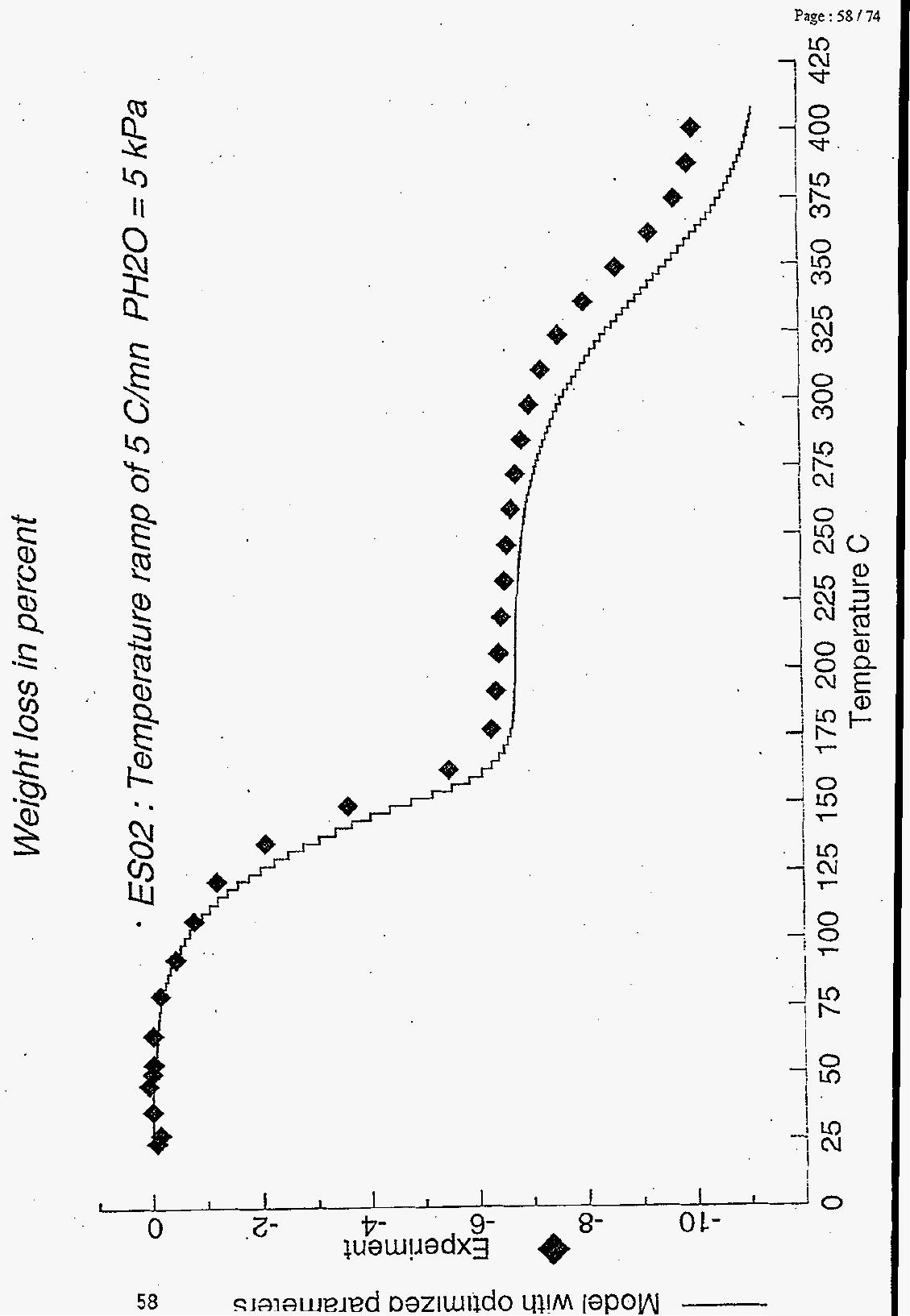


HNF-2262 Rev. 0

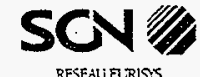

\begin{tabular}{|lrlll|}
\hline Type Doc. & Activit & Cat MT & Na dorors & Révision \\
NT & 10510 & 00 & 0004 & Rév. A \\
\hline
\end{tabular}

RESEAU ELRLSS

Page : $59 / 74$

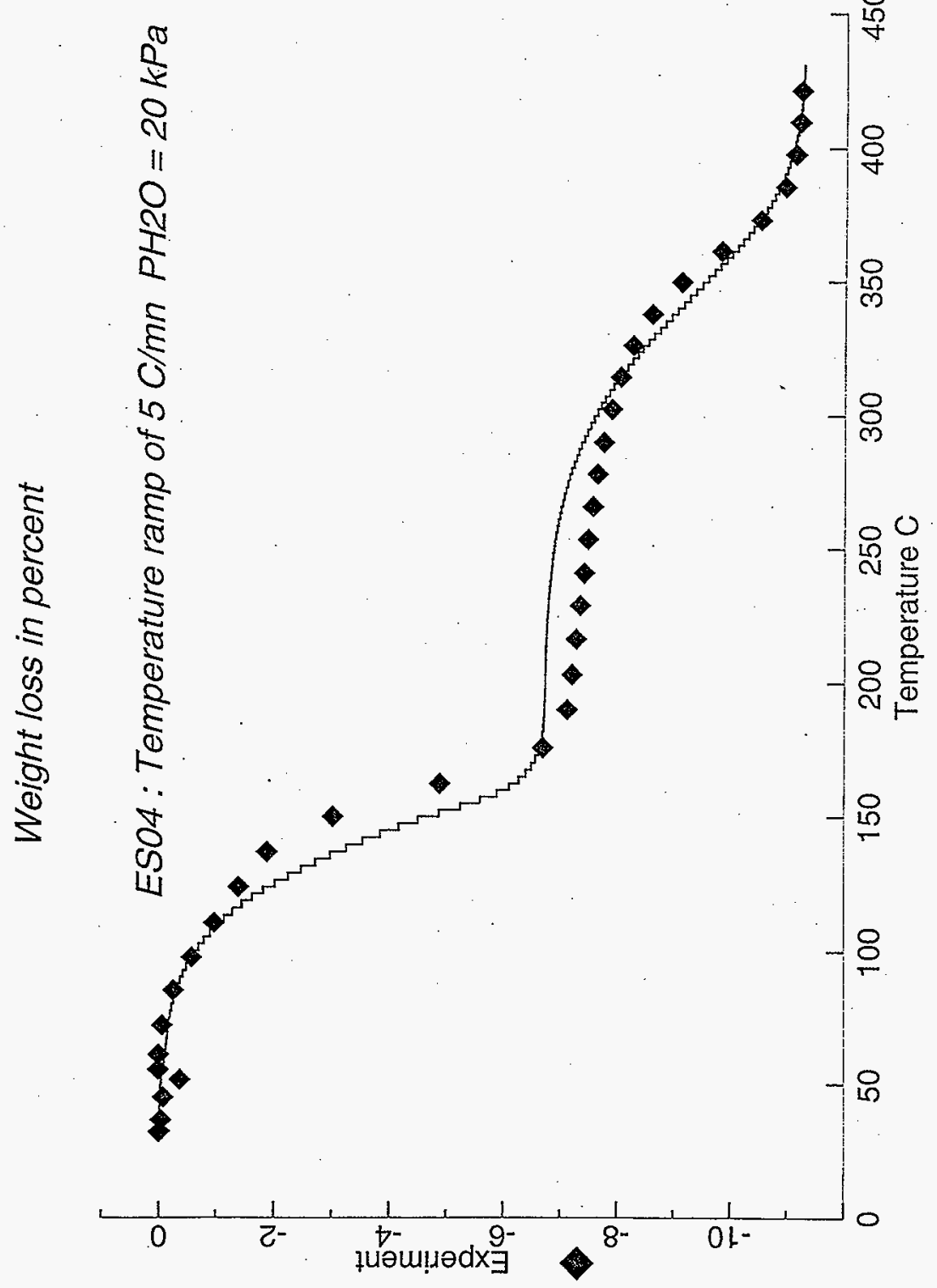


HNF-2262 Rev. 0

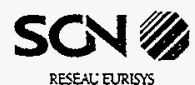

\begin{tabular}{|crllr|}
\hline Type Dos & Ativité & Cat.MT & No d'ordrc $^{\text {Révision }}$ \\
NT & 10510 & 00 & 0004 & Rév. A \\
\hline
\end{tabular}

RESEAL EURLYS

Page : $60 / 74$

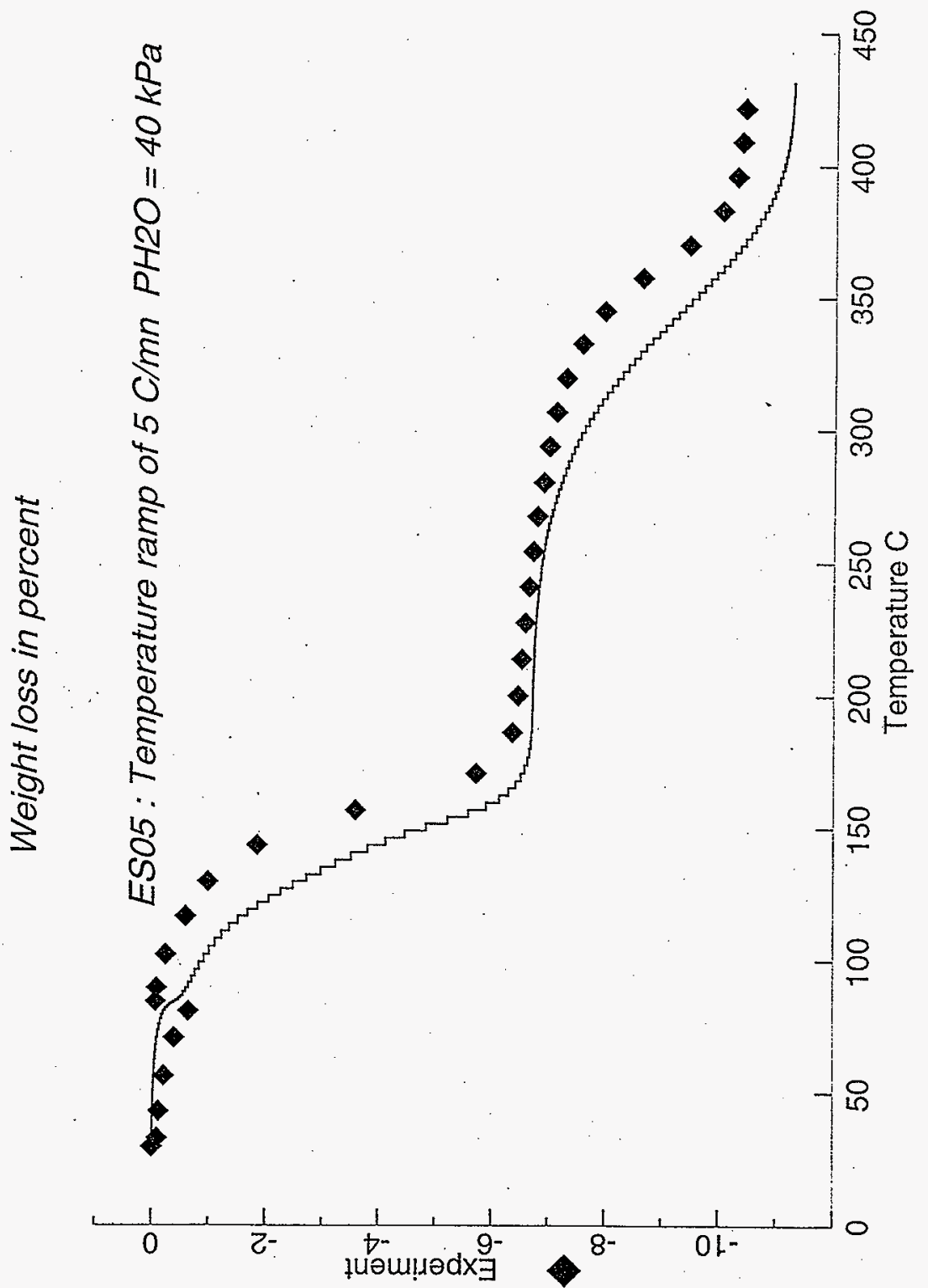


HNF-2262 Rev. 0

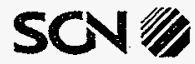

\begin{tabular}{|c|c|c|c|c|}
\hline Type Dos. & Acoivité & $\mathrm{C} 2 \mathrm{MT}$ & $N^{-6}$ d'ordse & Revision \\
\hline NT & 10510 & 00 & 0004 & Rév. A \\
\hline
\end{tabular}

RESEAU EURISS

Page : $61 / 74$

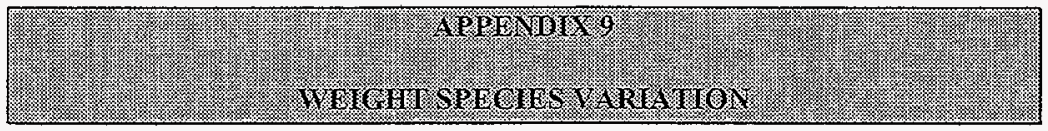


HNF-2262 Rev. 0

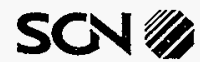

RESEAU EURLSYS

\begin{tabular}{|c|c|c|c|c|}
\hline Type Doc. & Acsinite & CatMT & Xं detdse & Reviston \\
\hline $\mathrm{NT}$ & 10510 & 00 & 0004 & Rév, A \\
\hline
\end{tabular}

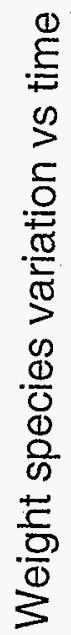

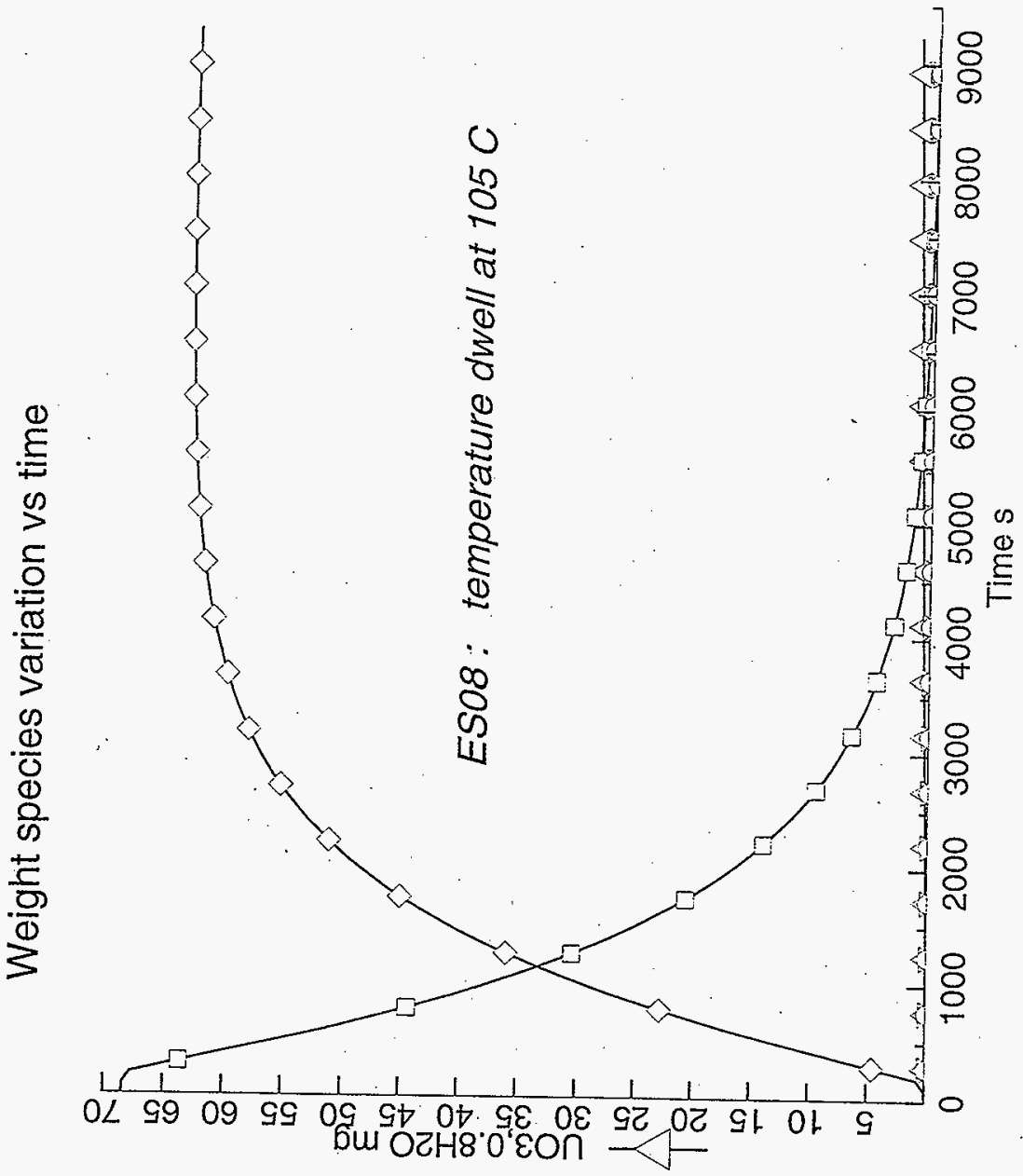

bu OZH'EOก

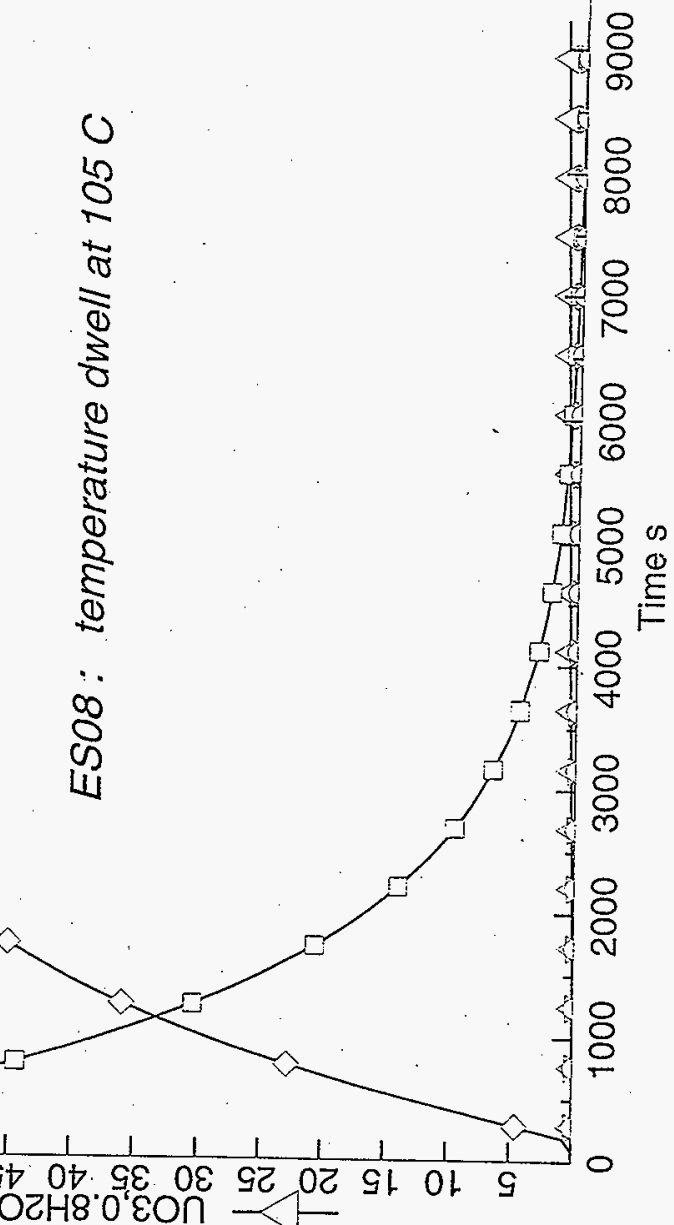

6u OZHZ'EOก $\square$

6u $80 \varepsilon n->$ 
HNF-2262 Rev. 0

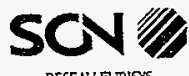

\begin{tabular}{lrlll}
\hline Type Doc. & Activité & CatMT & N" dordre & Rivision \\
NT & 10510 & 00 & 0004 & Rév. A
\end{tabular}

RESEAU EURISYS

Page : $63 / 74$

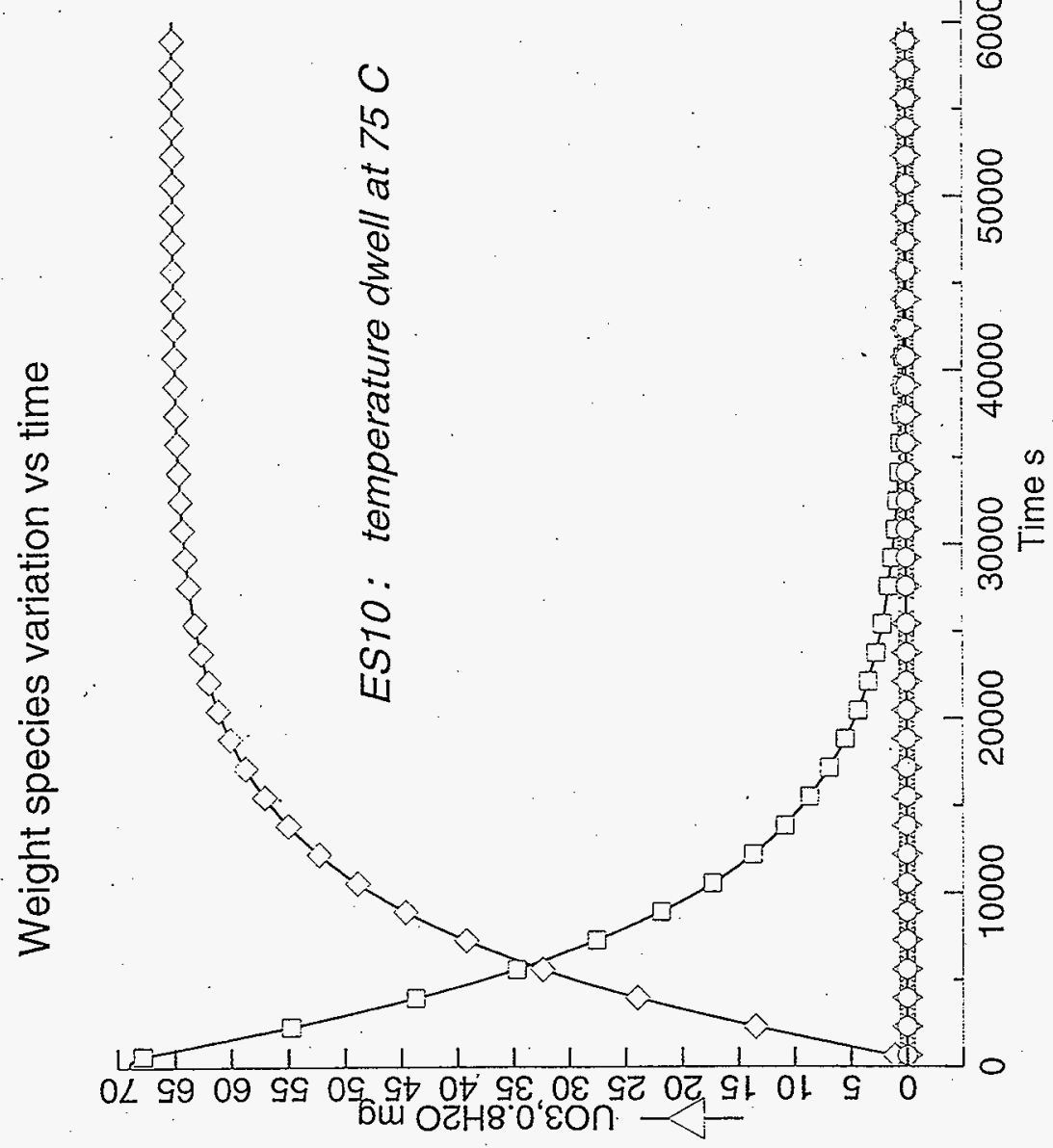

бщ OzH'\&Oก

om OZHZ'EOn -

бщ 80हก - 
HNF-2262 Rev. 0

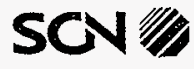

\begin{tabular}{|c|c|c|c|c|}
\hline Typc Doc. & Activite & CatMT & Nod'ordse & Révision \\
\hline NT & 10510 & 00 & 0004 & Rév, A \\
\hline
\end{tabular}

RESEAUEURLSS

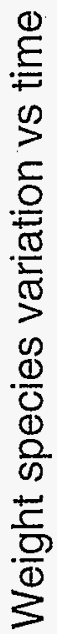

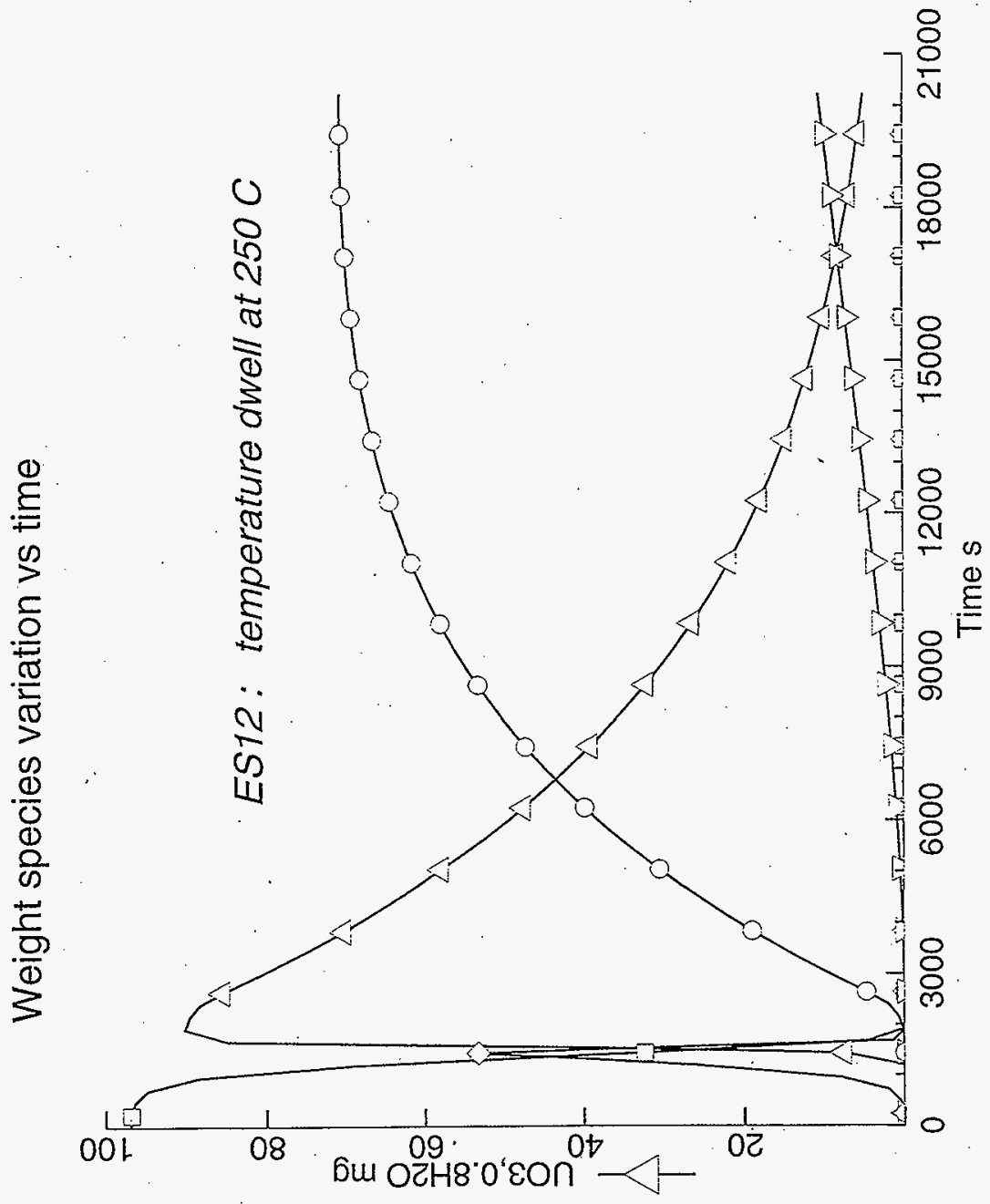

bu OZH'EOก

6u OZHZ'EOก -

bu $808 n->$

bu $80 \cap-2$ 
HNF-2262 Rev. 0 ,

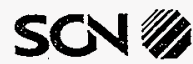

\begin{tabular}{|rrllr}
\hline Type Doe. & Aetivite & Cat MT & No ćotdre & Révision \\
NT & 10510 & 00 & 0004 & Rév, A \\
\hline
\end{tabular}

RESEAU EURISY

Page : $65 / 74$

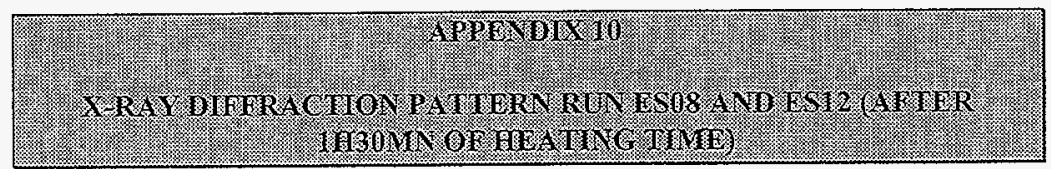


HNF-2262 Rev. 0

\begin{tabular}{|lrlll|}
\hline Type Doc. & Activite & Cat MT & No d"ordre $^{*}$ & Révision \\
NT & 10510 & 00 & 0004 & Rév. A \\
\hline
\end{tabular}

2)

-

26 $3=3$ 3

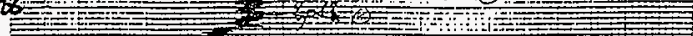

$20=23020$
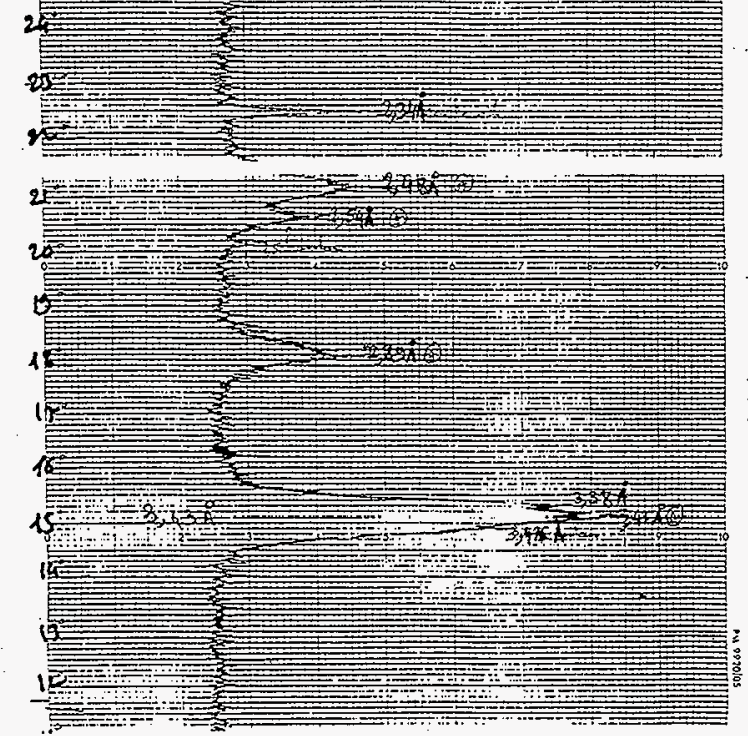

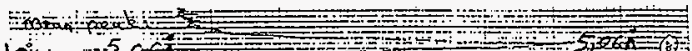

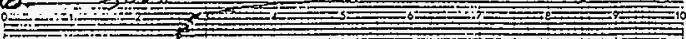

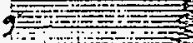

$10 \div \square \div \square$

$201=3$

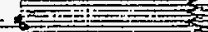

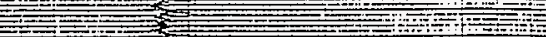

0

N $=1$

Z

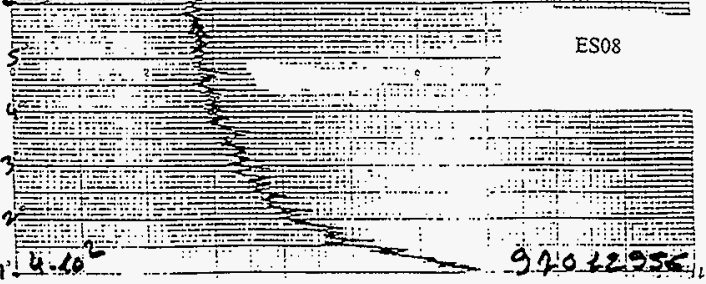




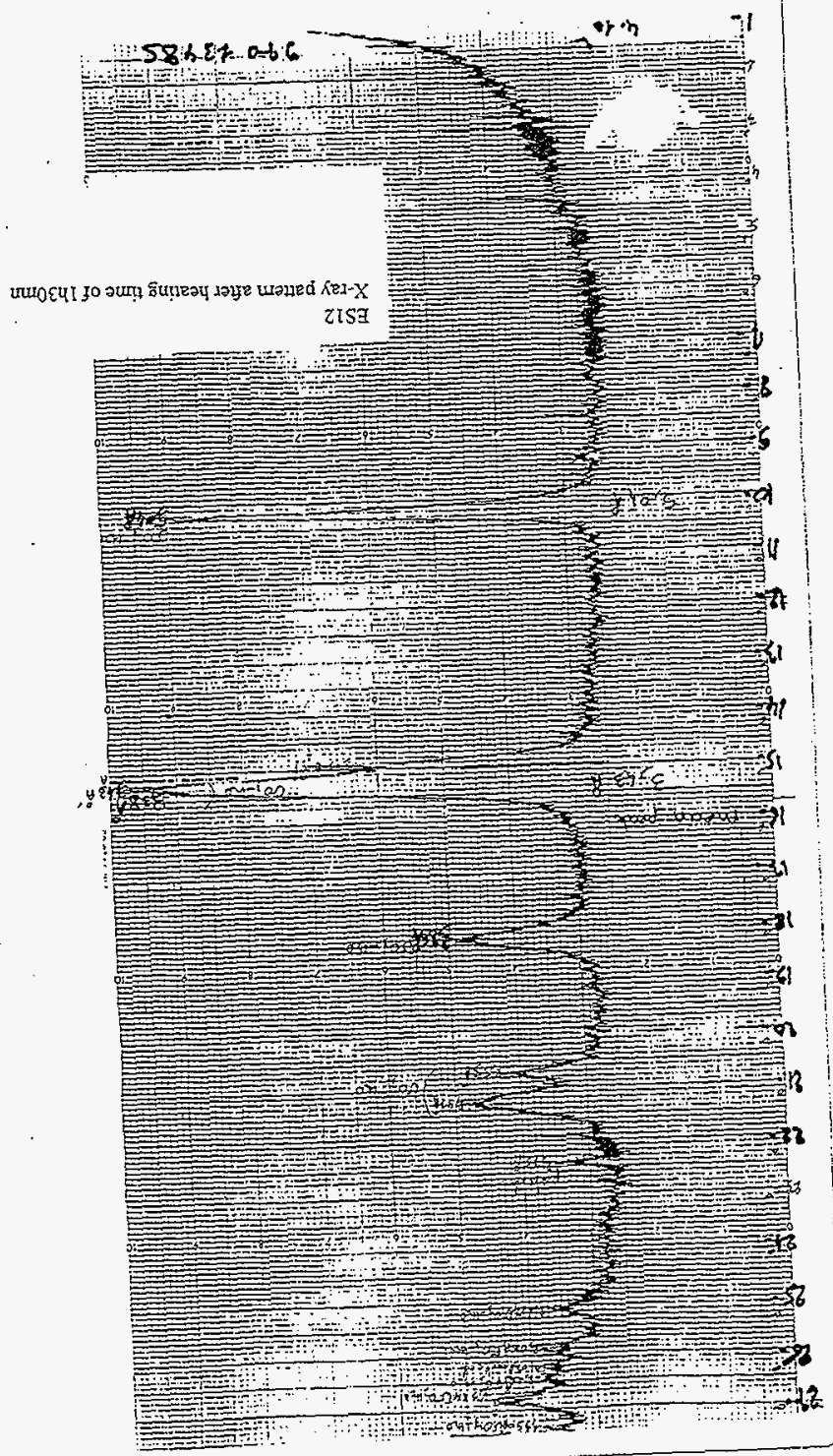

$\nabla L / \angle 9: 28 \mathrm{Ed}$

\begin{tabular}{|c|c|c|c|c|}
\hline 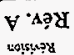 & $\begin{array}{r}7000 \\
\text { ระ } 71009 \text { ox }\end{array}$ & $\begin{array}{r}00 \\
w \times 5\end{array}$ & OLSOI & $\underset{* 0}{I N} \times R_{1}$ \\
\hline
\end{tabular}


HNF-2262 Rev. 0

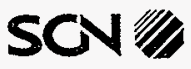

RESEAL:EURISYS

\begin{tabular}{|lllll|}
\hline Type Doc. & Activic & CatMT & No doodre & Révision \\
NT & 10510 & 00 & 0004 & Rév. A \\
\hline
\end{tabular}

Page : $68 / 74$

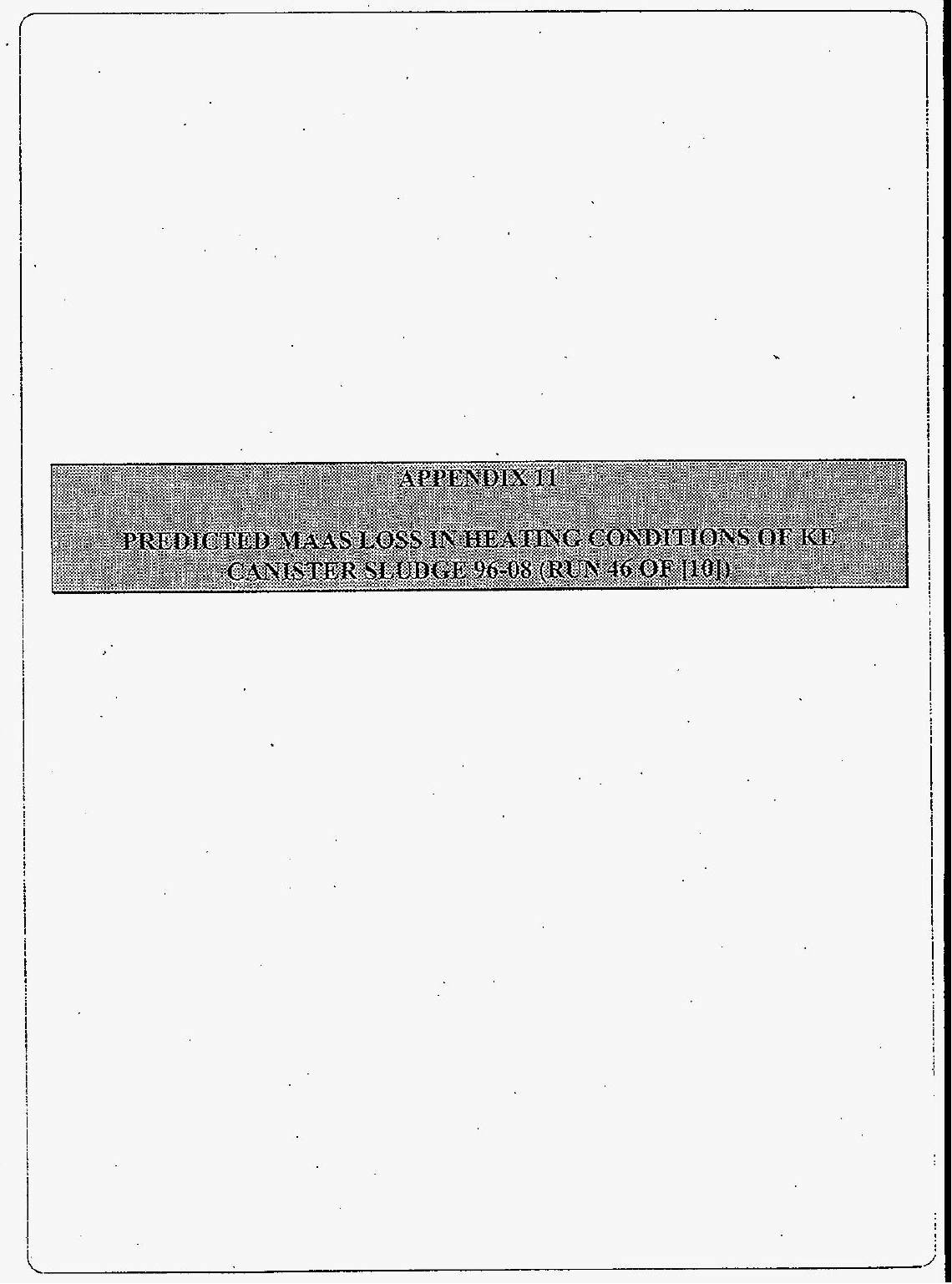


HNF-2262 Rev.0

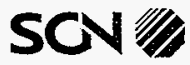

\begin{tabular}{lllll}
\hline Iype Doc. & Activié & Cat MT & No dordtre Révision \\
NT & 10510 & 00 & 0004 & Rév. A
\end{tabular}

RESEAU EURISTS

Page : $69 / 74$

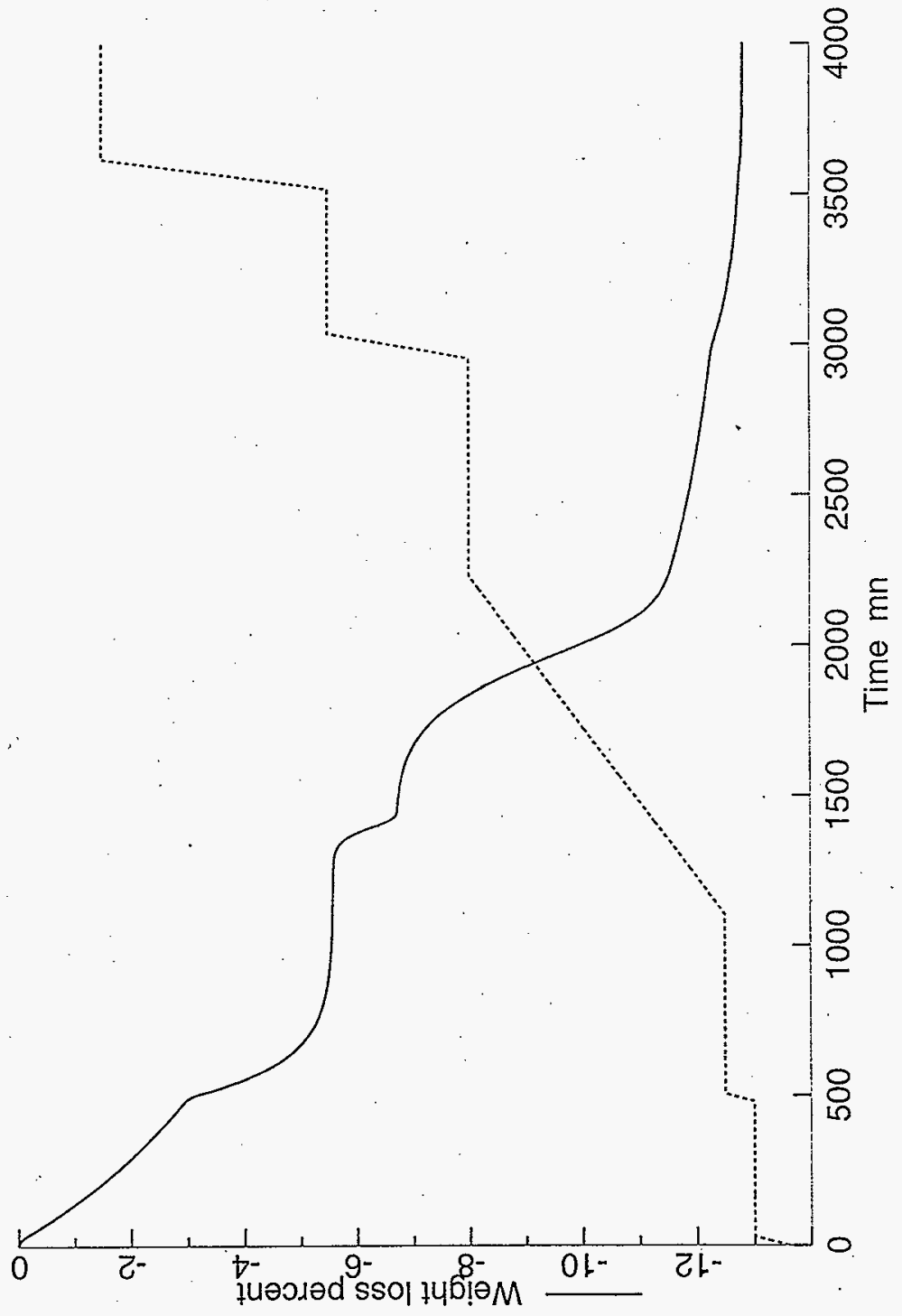


HNF-2262 Rev. 0

\begin{tabular}{|rrllr|}
\hline Type Doc. & Activité & Cat MT & No dordre & Rérision \\
NT & 10510 & 00 & 0004 & Rév. A
\end{tabular}

RESEAU EURISYS

Page : $70 / 74$

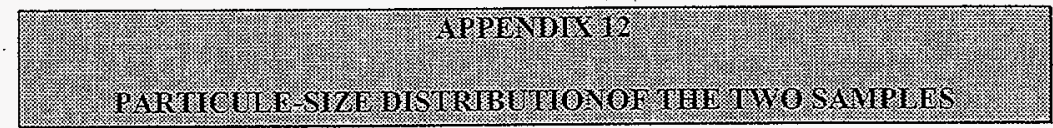


HNF-2262 Rev. 0

\begin{tabular}{|lrllr}
\hline Type Doc. & Ativize & CatMT & Ro dordre & Rérision \\
NT & 10510 & 00 & 0004 & Rév. A
\end{tabular}

Page : $71 / 74$

Imputation : SGN 063

Echantillon: $\mathrm{UO}_{3} .2 \mathrm{H}_{2} \mathrm{O}$ (immersion) produit 1

Commentaires :

Opérateur : $\mathbf{B O}$

Date de réception : 09/09/97

Date d'analyse : 14/10/97

Voie Liquide

Gamme : 0.05 à $900 \mu \mathrm{m}$

Théorie : Mie

Indice de réfraction de l'échantillon : $4.5295,0.1000$
indice de réfraction du dispersant : 1.3300

Dispersant: Eat

Type de résultat : Volume

Résultat d’analyse:

Fichier : C:ISIZERS/DATAVOO

$\mathrm{N}^{\circ}$. Enregistrement : $3>\mathrm{UO}_{3} .2 \mathrm{H}_{2} \mathrm{O}$ synt. eau

Diamètre à $50 \%: 1.05 \mu \mathrm{m}$

Diamètre à $10 \%: 0.26 \mu \mathrm{m}$

Diamètre a $80 \%: 14.75 \mu \mathrm{m}$
Obscuration : $27.30 \%$

Uniformite : $1225.11 \%$

Résiduel : $0,9219 \%$

10. $, \ldots \ldots+1, \ldots 1 t$, , . . .

$\infty$

69

0
$\vdots$
$\vdots$


$\vdots$


$\vdots$
$\vdots$
$\vdots$
$\vdots$
0.01
0
$\vdots$

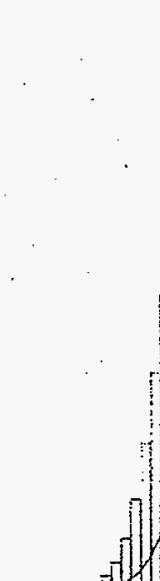

r. 


\begin{tabular}{|c|c|c|c|c|}
\hline Type Doc. & Activitét & $C_{21} N T$ & $\mathrm{~N}^{\circ} \mathrm{d}$ dordie & Révision \\
\hline $\mathrm{NT}$ & 10510 & 00 & 0004 & Rév, A \\
\hline
\end{tabular}

Page : $72 / 74$

Imputation: SGN 063
Fienier : C:ISIZERSDATAVUO3
N* Enregistremem : 3>VO3.2H2O symt eaU
Comnnentaizes:

Optroteur. 80

Dote de reception : $9109 / 97$

Dede Ganalyse : scroms97

Ectantion : LO3.2H2O:

Voie Humide: pompe:80\%, agialion:80\%. Us:0\%.

Protuit I Operateur : $B O$ (dete :1410/1997 15:34)

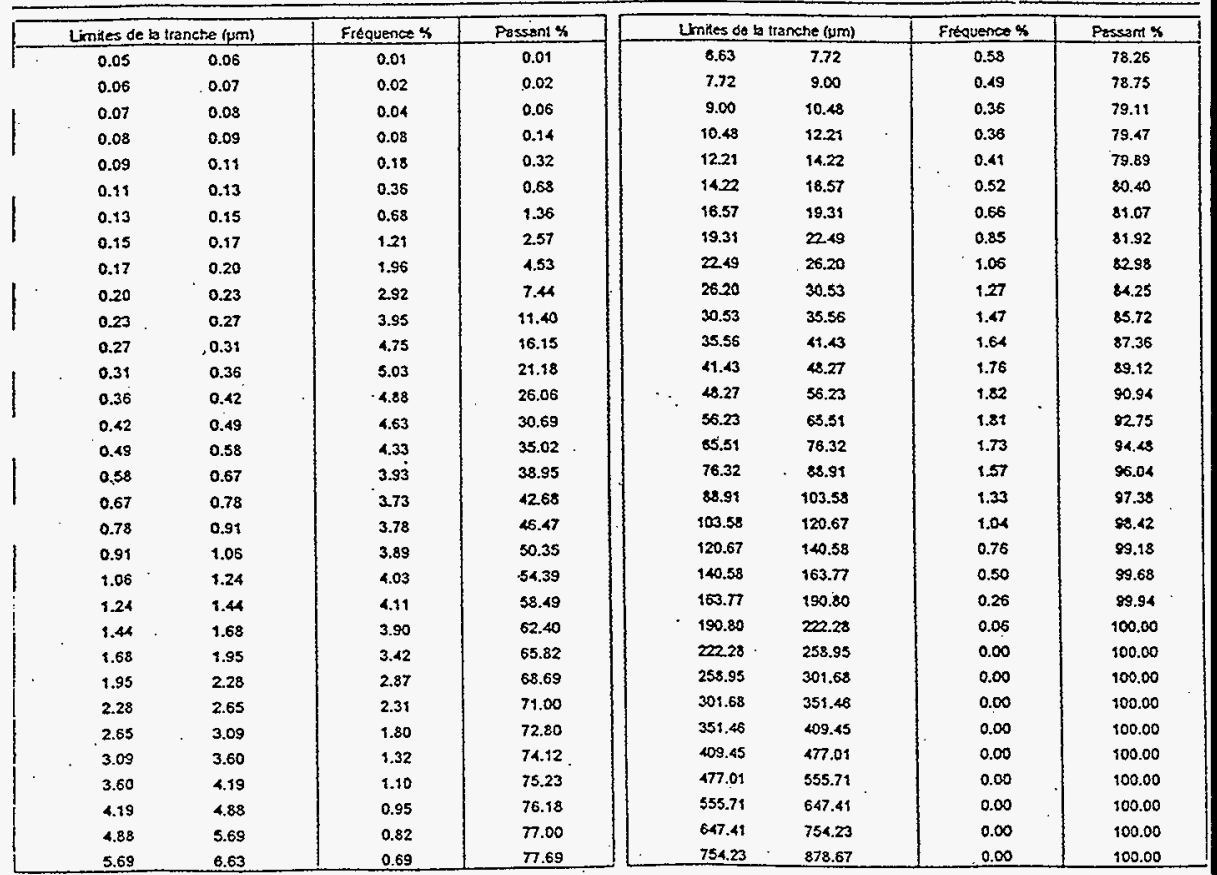


HNF-2262 Rev. 0

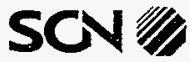

RESEAN EURLYS

\begin{tabular}{|lrlrr|}
\hline Type Dos. & Activite & Cun MT & $N^{\circ}$ doordre & Révision \\
NT & 10510 & 00 & 0004 & Rév. A \\
\hline
\end{tabular}

Page : $73 / 74$

\section{Distribution granulométrique Granulomètre laser}

imputation : SGN 063

Echantillon: $\mathrm{UO}_{3} 2 \mathrm{H}_{2} \mathrm{O}$ (air humide) produit 2

Commentaires:

Opérateur : $\mathrm{BO}$

Date de feception : 09/09/97

Date d'analyse : 14/10/97

\begin{tabular}{|c|c|c|}
\hline $\begin{array}{l}\text { Voie Liquide } \\
\text { Gamme : } 0.05 \text { a } 900 \mu \mathrm{m} \\
\text { Théorie: Mie } \\
\text { Indice de réfraction de l'échantillon : } 1.5295\end{array}$ & $\begin{array}{l}\text { Pompe: } 0.000 \mathrm{l} / \mathrm{sec} \\
\text { Dispersant: Eau } \\
\text { Type de résuitat : Volume } \\
5.0 .1000\end{array}$ & $\begin{aligned} \text { Agitation : } 0.00 \text { Tr/min } \\
\text { Ultrason : } \\
\text { Analyse : } \\
\text { Pause US }\end{aligned}$ \\
\hline
\end{tabular}

indice de réfraction du dispersant : 1.3300
Résultat d'analyse:

Fichier : C:ISIZERS/DATANOO

$\mathrm{N}^{\circ}$ Enregistrement : $2>\mathrm{UO}_{3} .2 \mathrm{H}_{2} \mathrm{O}$ synt. eau

$N^{\circ}$ de série de balayages: 1
Diamètre à $50 \%: 193.51 \mu \mathrm{m}$

Diamètre à $10 \%: 12.90 \mu \mathrm{\mu m}$

Diamètre à $80 \%: 395.40 \mu \mathrm{m}$
Obscuration: $18.27 \%$

Uniformité : $80.05 \%$

Résiduel : $0,3788 \%$

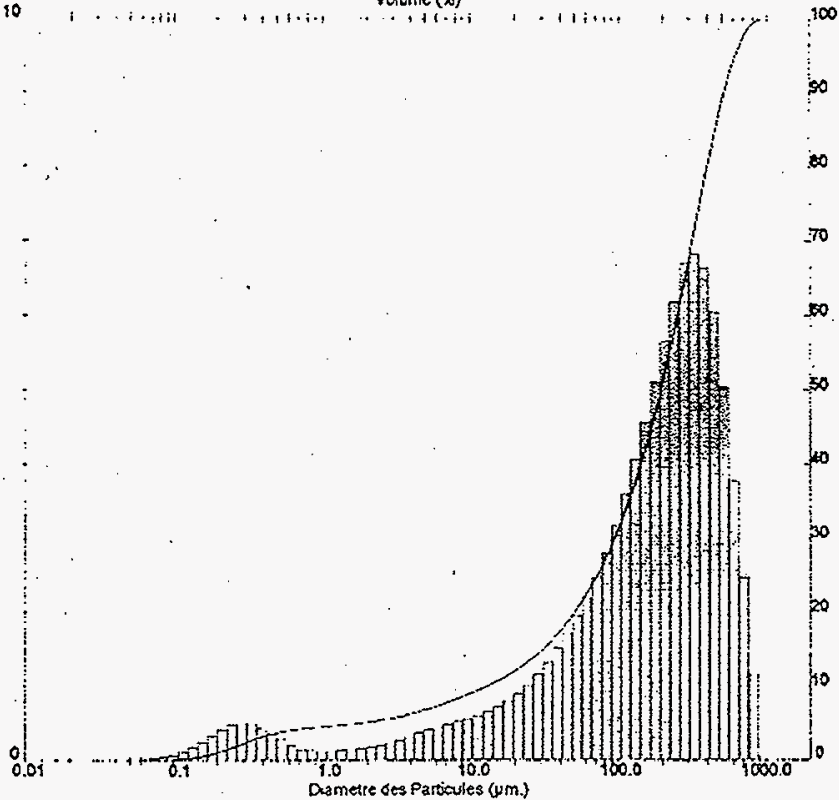


HNF-2262 Rev. 0

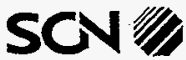

RESEAUEURISYS

\begin{tabular}{|lrlcr|}
\hline Type Doc. & Activite & Cat MT & N* dordse $^{\text {Revision }}$ \\
NT & 10510 & 00 & 0004 & Rév, A \\
\hline
\end{tabular}

Page : $74 / 74$

Operatew: 80

Imputation: SGN 063

Fichier : CALZZERSDATALO3

Date de reception : 909/97

$\mathrm{N}^{*}$ Enregistremem : $2>\mathrm{VO} 3,2 \mathrm{H} 2 \mathrm{O}$ ax humiso

Dute Garalyse : 14 to/1997

Commentsites:

Ectrantion: $1003,2 \mathrm{H} / 2 \mathrm{O}$ ar hurite

Protuit 2

Vole Humide: pornpo:80\%, agtation:80\%, US:0\%.

Operateur :EO (dste: : 4 wiors997 15:34)

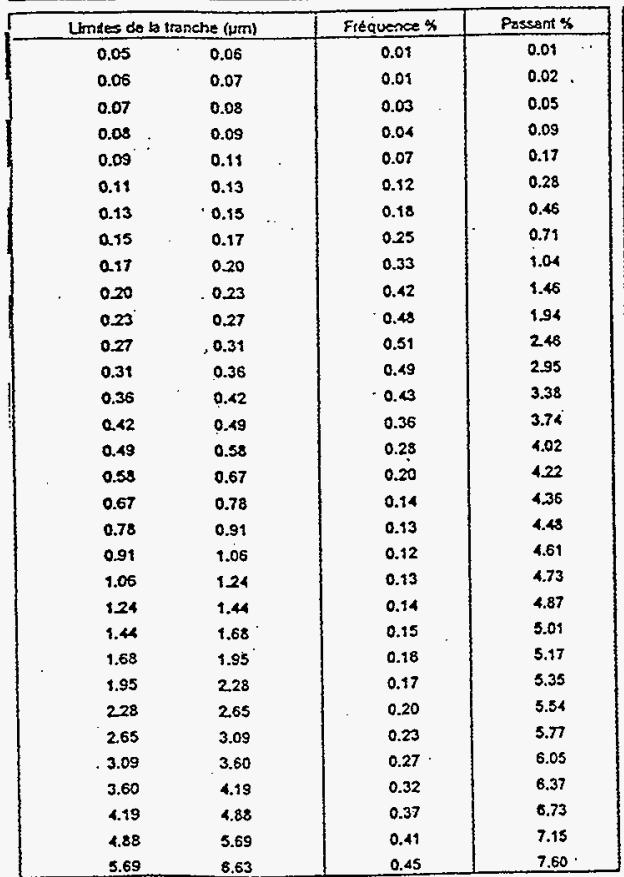

\begin{tabular}{|c|c|c|c|c|}
\hline \multicolumn{3}{|c|}{ Lintes de is tranche (1um) } & Ftequences $x$ & Pessant $x$ \\
\hline & 6.63 & 7.72 & 0.49 & 8.09 \\
\hline & 7.72 & 9.00 & 0.52 & 8.61 \\
\hline & 9.00 & 10.48 & 0.56 & 9.17 \\
\hline & 10.48 & 1221 & 0.60 & 9.77 \\
\hline & 12.21 & 14.22 & 0.65 & 90.42 \\
\hline & 14.22 & 16.57 & 0.72 & 11.14 \\
\hline & 16.57 & 19.31 & 0.80 & 11.94 \\
\hline & 19.31 & 22,49 & 0.90 & 1283 \\
\hline & 22.49 & 28.20 & 1.02 & 13.85 \\
\hline & 26.20 & 30.53 & 1.16 & 15.01 \\
\hline & 30.53 & 35.56 & $\$ .33$ & 16.34 \\
\hline & 35.56 & 41.43 & 1.51 & 17.85 \\
\hline & 41.43 & 48.27 & 1.72 & 19.57 \\
\hline & 49.27 & 56.23 & 1.84 & 21.51 \\
\hline$\cdots$ & $\therefore \quad 56.23$ & 65.51 & 220 & 23.70 \\
\hline & 65.51 & 76.32 & 248 & 26.18 \\
\hline & 76.32 & 38.91 & 281 & 28.99 \\
\hline & 88.91 & 103.58 & 3.18 & 32.17 \\
\hline & 103.58 & 120.67 & 3.60 & 35.76 \\
\hline & 120.67 & 140.58 & 4.06 & 39.83 \\
\hline & 140.58 & 163.77 & 4.57 & 4.39 \\
\hline & 163.77 & 190.80 & 5.10 & 49.50 \\
\hline & - 180.80 & 22228 & 5.65 & 55.15 \\
\hline & 222.28 & 258.95 & 6.18 & 61.33 \\
\hline & 258.95 & 301.68 & 6.69 & $\$ 8.02$ \\
\hline - & 301.68 & 351.45 & 6.83 & 74.85 \\
\hline & 351.48 & 409.45 & $6.63^{\circ}$ & 81.48 \\
\hline & 409.45 & 477.01 & 6.04 & 87.52 \\
\hline & 477.01 & 555.71 & 5.04 & 92.57 \\
\hline & 555.71 & 847.41 & 3.79 & 95.35 \\
\hline & 647.41 & 754.23 & 248 & 98.83 \\
\hline & 754.23 & 378.67 & 1.17 & 100.00 \\
\hline
\end{tabular}


DISTRIBUTION SHEET

\begin{tabular}{|c|c|c|c|c|c|}
\hline \multirow{2}{*}{$\begin{array}{l}\text { To } \\
\text { Distribution }\end{array}$} & \multirow{2}{*}{\multicolumn{3}{|c|}{$\begin{array}{l}\text { From } \\
\text { SNF Characterization Project }\end{array}$}} & \multicolumn{2}{|c|}{ Page 1 of 1} \\
\hline & & & & \multicolumn{2}{|c|}{ Date $02 / 18 / 98$} \\
\hline \multirow{2}{*}{\multicolumn{4}{|c|}{$\begin{array}{l}\text { Project Title/Work Order } \\
\text { Thermal Decomposition of } \mathrm{UO}_{3} \cdot 2 \mathrm{H}_{2} \mathrm{O} \text {, Rev. } 0\end{array}$}} & \multicolumn{2}{|c|}{ EDT No. 620800} \\
\hline & & & & \multicolumn{2}{|l|}{ ECN No. } \\
\hline Name & MSIN & $\begin{array}{l}\text { Text } \\
\text { With All } \\
\text { Attach. }\end{array}$ & Text Only & $\begin{array}{l}\text { Attach./ } \\
\text { Appendi> } \\
\text { Only }\end{array}$ & $\begin{array}{c}\text { EDT/ECN } \\
\text { Only }\end{array}$ \\
\hline
\end{tabular}

Fluor Daniel Hanford, Inc.

R. L. McCormack

B\&W Protec, Inc.

T. L. WeTsh

Duke Engineering \& Services

Hanford, Inc.

R. B. Baker

L. D. Bruggeman

J. Perez-Carter

D. R. Duncan

J. R. Frederickson

L. H. Goldmann

L. A. Lawrence

B. J. Makenas

R. P. Omberg

W. H. Rasin

A. M. Segresti

D. J. Trimbie

J. H. Wicks

SNF Project File

Fauske \& Associates

M. G. Plys

Fluor Daniel Northwest

R. D. Crowe

Numatec Hanford Corporation

G. P. Chevrier

T. A. Flament

C. R. Miska

C. Pili-Vincens

J. P. Sloughter

H0-40

HO- 40

HO- 40

R3-86

R3-86

R3-86

$\mathrm{HO}-40$

$\mathrm{H} 0-40$

$\mathrm{HO}-40$

R3-11

R3-13

HO- 40

R3-11

R3-11

S7-14

$x$

R3-26

$x$

Pacific Northwest National Laboratory

3. Abrefah

S. C. Marschman

Central Files
R3-86

R3-86

R3-86

R3-86

H5- 49 $x$
$x$
$x$
$x$
$x$
$x$
$x$
$x$
$x$
$x$
$x$
$x$
$x$
$x$$$
\sqrt{x}
$$

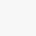

